\author{
UNIVERSIDADE DE SÃO PAULO \\ FACULDADE DE FILOSOFIA LETRAS E CIÊNCIAS HUMANAS \\ DEPARTAMENTO DE GEOGRAFIA \\ CURSO DE PÓS-GRADUAÇÃO EM GEOGRAFIA \\ ÁREA DE CONCENTRAÇÃO EM GEOGRAFIA HUMANA
}

O TURISMO, O REENCONTRO E A REDESCOBERTA

DA REGIÃO DAS MISSÕES

CARMEN REGINA DORNELES NOGUEIRA

São Paulo. 


\author{
UNIVERSIDADE DE SÃO PAULO \\ FACULDADE DE FILOSOFIA LETRAS E CIÊNCIAS HUMANAS \\ DEPARTAMENTO DE GEOGRAFIA \\ CURSO DE PÓS-GRADUAÇÃO EM GEOGRAFIA \\ ÁREA DE CONCENTRAÇÃO EM GEOGRAFIA HUMANA
}

\title{
O TURISMO, O REENCONTRO E A REDESCOBERTA DA REGIÃO DAS MISSÕES
}

\section{CARMEN REGINA DORNELES NOGUEIRA}

Tese apresentada ao Programa de PósGraduação em Geografia Humana do Departamento de Geografia da Faculdade de Filosofia, Letras e Ciências Humanas da Universidade de São Paulo, para obtenção do título de Doutor em Geografia sob a orientação do Professor Dr. Francisco Capuano Scarlato.

São Paulo. 


\section{CARMEN REGINA DORNELES NOGUERIA}

\section{O TURISMO, O REENCONTRO E A REDESCOBERTA DA REGIÃO DAS MISSÕES}

Tese apresentada ao Programa de Pós-Graduação em Geografia Humana aprovado pela Banca Examinadora constituída pelos seguintes professores:

Professor Dr.Francisco Capuano Scarlato - Orientador DG/FFLCH/USP

Professora Dra. Amália Inês Geraiges de Lemos DG/FFLCH/USP

Professor Dr Julio Cesar Suzuki DG/FFLCH/USP

Professor Dr. Julio Ricardo Quevedo dos Santos MILA/CCSH/UFSM

Professor Dr. Reinaldo Miranda de Sá Teles ECAVUSP 


\begin{tabular}{|c|c|}
\hline Eram armas de Castela & Da mandioca e milharais. \\
\hline \multicolumn{2}{|l|}{ Que vinham do mar de } \\
\hline \multicolumn{2}{|l|}{ além; } \\
\hline De Portugal também & Ninguém a vida roubava \\
\hline vinham, & Do semelhante cristão, \\
\hline Dizendo, por nosso bem: & Nem a pobreza existia \\
\hline Mas quem faz gemer a & Que chorasse pelo pão; \\
\hline terra... & Jesus-Cristo era contente \\
\hline Em nome da paz não vem! & E dava sua benção... \\
\hline Mandaram por serra acima & Por que vinha aquele mal, \\
\hline Espantar os corações; & Se o pecado não havia?... \\
\hline Que os Reis Vizinhos & O tributo se pagava \\
\hline queriam & Se o vizo-rei o pedia, \\
\hline Acabar com as Missões, & E até sangue se mandava \\
\hline Entre espadas e mosquetes, & Na gente moça que ia... \\
\hline \multirow[t]{2}{*}{ Entre lanças e canhões!... } & Eram armas de Castela \\
\hline & Que vinham do mar de além; \\
\hline \multirow[t]{2}{*}{ Cheiravam as brancas flores } & De Portugal também vinham, \\
\hline & Dizendo, por nosso bem: \\
\hline Sobre os verdes laranjais; & Mas quem faz gemer a terra... \\
\hline Trabalhava-se na folha & Em nome da paz não vem! \\
\hline Que vem dos altos ervais; & (Lunar de Sepé de João Simão Lopes \\
\hline Comia-se das lavouras & Neto.) \\
\hline
\end{tabular}


Aos meus pais

Moacir e Maria 


\section{AGRADECIMENTOS}

Ao finalizar um trabalho aparentemente solitário como este, faz-se necessário agradecer àqueles que, ao longo do caminho, se apresentaram como auxílio necessário em determinado momento da caminhada. A todos meus sentimentos de gratidão sincera.

Ao Professor Dr. Francisco Capuano Scarlato pela qualidade da orientação recebida e, pela amizade e confiança a mim demonstradas.

À Universidade Regional Integrada do Alto Uruguai e das Missões por possibilitar a realização do curso. Ao Centro de Cultura Missioneira, especialmente nas pessoas das funcionárias Lorena e Nadir Lurdes Damiani pela atenção especial dispensada no atendimento, indicação e disponibilização de acervo bibliográfico e documental. Ao Núcleo de Geoprocessamento na pessoa do aluno/estagiário Luis Henrique Foletto pelo auxílio na elaboração de mapas. Ao setor de Comunicação na pessoa da funcionária Eliete Carvalho pelo auxílio na impressão deste trabalho. Ao Laboratório de Estudos de Geografia Humana, nas pessoas das alunas/estagiárias Andréa Mendes do Nascimento, Tânia Secretti e Mairim Russo Serafini pelo valioso auxílio e carinho demnostrado. 
A família Mathioni Rigolli pelo importante incentivo e compreensão em momentos de extrema dificuldade. Ao Rodrigo Otávio Mathioni Hannel pela "pacenciosa renúncia”.

A amiga Beatriz Pinto pela revisão do trabalho, pelo apoio e carinho demonstrado.

Aos "anjos amigos": Lucimar, Mauro e Aline, pelo apoio incondicional e pelo suporte logístico prestado; Reinaldo, Marli, Ricardo, Rafael, Fátima, Nelson, Carlos e Nelci, Gláucio e Deise pela amizade e incentivo constante. 


\section{SUMÁRIO}

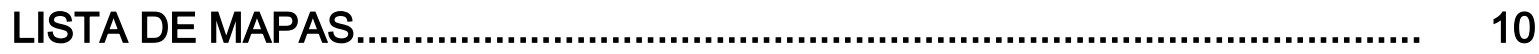

LISTA DE 11

QUADROS.

LISTA DE ILUSTRAÇÕES...................................................................... 13

LISTA DE FOTOS.................................................................................. 14

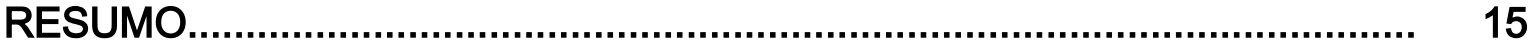

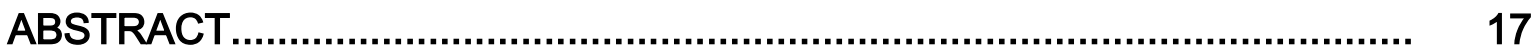

INTRODUÇÃO................................................................................... 19

1 MISSÕES JESUITTICO-GUARANI: A FORMAÇÃO DE UMA

REGIÃO TRANSFRONTEIRIÇA............................................................. 24

1.1 As Missões Jesuítico-Guarani.................................................................. 24

1.1.1 Estrutura Espacial de uma Redução................................................... 38

1.2 A Formação de uma Região Transfronteiriça......................................... 47

1.2.1 Tratado de Tordesilhas ...................................................................... 53

1.2.2 Tratado de Madrid............................................................................... 54

1.2.3 Tratado de El 58

Pardo.

1.2.4 Tratado de Paris.................................................................................. 59

1.2.5 Tratado de Santo Ildefonso................................................................ 60

1.2.6 Tratado de Badajós............................................................................. 62

2 MISSÕES JESUÍTICO-GUARANI E A FORMAÇÃO DO

TERRITÓRIO DO RIO GRANDE DO SUL................................................ 64

2.1 Período Pré-jesuítico.............................................................................. 65

2.2 Período Jesuítico............................................................................. 73 
3 MISSÕES JESUÍTICO-GUARANI E DESENVOLVIMENTO REGIONAL:

UM OLHAR PARA O FUTURO ........................................................ 96

3.1 Patrimônio Arquitetônico das Missões e sua Importância Turística.......... 104

3.2 Projetos e Programas Voltados ao Turismo Regional.............................. 113

3.2.1 Circuito Internacional das Missões Jesuíticas........................................ 113

3.2.2 Projeto Integrado de Valorização dos Sítios Arqueológicos

Missioneiros do Brasil.

3.2.3 Programa de Capacitação para Conservação, Gestão e

Desenvolvimento Sustentável das Missões Jesuíticas dos Guarani.

3.2.4 Caminho das Missões

3.2.5 Rota Missões.

3.2.6 Rede Regional de Conhecimento do Circuito Internacional das

Missões Jesuíticas.

3.2.7 Programa de Cooperação Técnica para Roteirização:Iguaçu-Missões.. 147

3.2.8 Prograqma de Cooperação Instituto Andaluz - Instituto do Patrimônio Histórico e Artístico Nacional.

CONSIDERAÇÕES

FINAIS.

REFERÊNCIAS 
LISTA DE ILUSTRAÇÕES - MAPAS

1. MAPA LOCALIZAÇÃO DAS MISSÕES NA AMÉRICA LATINA.............. 25

2. MAPA LOCALIZAÇÃO DA ÁREA DE ESTUDOS.................................. 26

3. MAPA ÁREA DE EXPANSÃO DAS REDUÇÕES.................................. 28

4. MAPA LOCALIZAÇÃO DOS TRINTA POVOS DAS MISSÕES............... 33

11. MAPA LIMITE DAS ESTÂNCIAS MISSIONEIRAS................................ 43

12. MAPA TRATADO DE TORDESILHAS .............................................. 54

13. MAPA TRATADO DE MADRID......................................................... 55

14. MAPA TRATADO DE MADRID .................................................. 58

15. MAPA TRATADO DE PARIS.............................................................. 60

16. MAPA TRATADO DE SANTO ILDEFONSO........................................... 62

17. MAPA LOCALIZAÇÃO DOS GUARANI PRÉ-JESUÍTICOS................... 66

24. MAPA EXPANSÃO PORTUGUESA RUMO AO PRATA...................... 84

37. MAPA CIRCUITO INTERNACIONAL DAS MISSÕES JESUÍTICAS....... 115

46. MAPA CAMINHO DAS MISSÕES................................................... 136

47.MAPA ÁREA DE ABRANGÊNCIA DO PROJETO DE ROTEIRIZAÇÃO IGUAÇU-MISSÕES................................................................. 151 


\section{LISTA DE FIGURAS - QUADROS}

5.QUADRO REDUÇÕES JESUÍTICO-GUARANI NA ARGENTINA.......... 34

6. QUADRO REDUÇÕES JESUÍTICO-GUARANI NO PARAGUAI............. 35

7. QUADRO REDUÇÕES JESUÍTICO-GUARANI NO BRASIL PRIMEIRO CICLO......................................................... 36

8. QUADRO REDUÇÕES JESUÍTICO-GUARANI NO BRASIL SEGUNDO CICLO.......................................................... 38

10. PRINCIPAIS ELEMENTOS ARQUITETÔNICOS DE UMA

QUADRO REDUÇÃO........................................................... 41

25. PATRIMÔNIO ARQUITETÔNCIO DAS MISSÕES -

QUADRO ARGENTINA............................................................... 89

26. PATRIMÔNIO ARQUITETÔNCIO DAS MISSÕES -BRASIL 92

QUADRO

27.QUADRO PATRIMÔNIO ARQUITETÔNCIO DAS MISSÕES PARAGUAI............................................................. 93

28.QUADRO DOCUMENTOS QUE NORTEIAM A PRESERVAÇÃO 100 PATRIMONIAL

38.QUADRO ROTEIRO DO CIRCUITO E SUAS PRINCIPAIS CARACTERÍSITICAS....................................................... 119

39.QUADRO COMPARATIVO SITUAÇÃO REGIÃO................................. 120

40.QUADRO OPERACIONALIZAÇÃO E NECESSIDADES REGIONAIS... 125

.41QUADRO CONCLUSÕES E RECOMENDAÇÕES DO PRIMEIRO CURSO-OFICINA/2003.................................................... 129

42.QUADRO NECESSIDADES ESPECÍFICAS ......................................... 130 
43.QUADRO AÇÕES DESENVOLVIDAS EM 2004.............................. 131

44.QUADRO CONCLUSÕES E RECOMENDAÇÕES DO SEGUNDO CURSO-OFICINA/2004................................................... 132

45.QUADRO ROTEIRO DO CAMINHO DAS MISSÕES............................ 135

48.QUADRO PRINCIPAIS ATRATIVOS DO ROTEIRO IGUAÇUMISSÕES.................................................................. 153

49.QUADRO OBJETIVOS E RESULTADOS ESPERADOS DO PROJETO. 


\section{LISTA DE ILUSTRAÇÕES}

9. DESENHO VISTA DE UMA REDUÇÃO........................................ 40

18. GRAVURA O ESPAÇO INTERNO DA HABITAÇÃO GUARANI......... 67 19 GRAVURA HABITAÇÃO GUARANI................................................... 68

20 DESENHO ALDEIA GUARANI....................................................... 69

21 DESENHO TE KO-HÃ.............................................................. 72

22 TELA PLANTA DE UMA REDUÇÃO.

76

23 TELA O ESPAÇO INTERNO DA REDUÇÃO. 


\section{LISTA DE ILUSTRAÇÕES - FOTOS}

29. FOTO

30. FOTO

31. FOTO

32. FOTO

33.FOTO

34.FOTO

35.FOTO

36.FOTO
Sítio Arqueológico de São Miguel-Brasil.

105

Sítio Arqueológico de San Ignácio Mini-Argentina. 105

Sítio Arqueológico de San Ignácio Mini-Argentina.. 106

Sítio Arqueológico Santa Ana-Argentina.......................... 106

Sítio Arqueológico Loreto-Argentina............................... 107

Sítio Arqueológico de Santa Maria Argentina.................. 107

Sítio Arqueológico de Jesus-Paraguai.............................. 108

Sítio Arqueológico de Trinidad-Paraguai..

108 


\section{RESUMO}

O presente trabalho consta da descrição explicativa dos processos de ocupação da Região das Missões Jesuítico-Guarani, que contribuíram para que a mesma tenha se constituído hoje, em uma "Região Turística Transfronteiriça". Sua configuração atual resulta do processo de expansão colonial ibérica e das relações que se estabeleceram entre os colonizadores e os habitantes locais e, entre ambos e o ambiente com seus recursos. Constatou-se que sua singularidade é uma conseqüência dos processos históricos que são evidenciados em três períodos bem característicos: Período pré-jesuítico: caracterizado pela organização dos Guarani em pequenas comunidades, que ocupavam os lugares com solo fértil para a prática da agricultura, como as várzeas dos grandes rios, vales e lugares com matas. Mantinham uma relação ecológica com o território, retirando da terra somente o necessário à sua sobrevivência. Período jesuítico: no qual houve a "redução" da comunidade indígena, que passou a manter uma nova forma de se relacionar com o território; implantando, ao mesmo tempo, um sistema de produção coletivo-complementar, aliado a um sistema comercial responsável por enviar, para a Europa, produtos como sebo, erva-mate, algodão, chifre e couro. Período pós-jesuítico: vai, desde a derrocada das Missões até os dias de hoje. Caracterizado pelos desajustes sociais, econômicos e ambientais, frutos das expansões agropecuárias, mineiras e industrial, baseada em um modelo que se caracterizou pelo deterioramento do meio ambiente como custo necessário ao progresso, não se mostrou viável para resolver os problemas econômicos e sociais da população regional. Esse período caracteriza-se também pela busca de soluções para os problemas regionais, através da dinamização do uso público do rico patrimônio histórico-cultural através do turismo. Surgem projetos e programas voltados para a dinamização do turismo regional, no entanto os mesmos não atingiram totalmente os objetivos a que se propuseram. $O$ uso do método evolutivo histórico, a partir da pesquisa bibliográfica e da pesquisa de campo, com observação direta sistematizada e realização de entrevistas, proporcionou o alcance dos objetivos de: analisar a importância das Missões Jesuíticas na consolidação das fronteiras do sul do Brasil; analisar a situação dos sítios arqueológicos das antigas reduções jesuítico- 
Guarani, avaliar a importância dos remanescentes arquitetônicos das reduções como potencial turístico; analisar os programas e projetos propostos para a Região das Missões em relação ao turismo, além de fornecer subsídios que possam contribuir para a implementação, intensificação e expansão da atividade turística regional.

Palavras-Chave: Reduções Jesuítico-Guarani; Consolidação de Fronteiras;. Patrimônio Histórico-Cultural; Região Turística Transfronteiriça; Turismo. 


\section{ABSTRACT}

The present work is a descriptive explanation of the processes of the occupation of the Jesuit-Guarani Missions, which ended up transforming it into a tourist atiraction beyond borders. Its present-day status is a resu of the relations which have been established between the Iberian sett and the Local inhabitants and arnong thernselves, and the environrnent with its resources It cari be said that its singularity is a consequence of the historie processes which are evident $i$ three well-defrned periods: Pre-Jesuit period it is characterized by the organization of the Guarani Indians in srnall communities which occupied places having a fertile sou, good for agriculture, like the flat lands along rivers, valleys and woodland. They maintained an ecological relation with lhe territory, extracting from the sou only the every day necessities for their survival. Jesuit Period: in which there was a "reduction" of Ihe Indian cornmunit and which started a new way of interaction with the territory, irnplernenting, at the sarne time, a coilective cornplernentary production system together with a business-like system responsible for sending to Europe products like tallow, rnate, cotton, bom and leather. Post-Jesuit Period: beginn ing since lhe destruction of the Missions liii nowadays. li is characterized by social , economical and environmental i due to agronornic, mineral and industrial expansion, based on a model which is characterized by lhe deterioration ofthe environnient as a by-product ofprogress, not being able to solve the economie and social. Probtems ofthe regional population. This period is also characterized because of a search for solutions for regional problems, througli a dynarnic use of its ricli cultural-historical touristic patrirnony . The use of the historical evolutionary rnethod, through bihliographic and field research, with direci and systernatic observation and interviews led to the foliowing objectives: to analyze the irnportance of the Jesuit Missions in the consolidation of the Southern Brazilian boundaries; to analyze the situation of the archeological sites of lhe formem Jesuit-Guarani reductions, to evaluate the importance of the architectonic remainings ofthe old Jesuit-Guarani reductions as a touristic potential; lo analyze Ihe prograrns and the projects destined to Ihe Missions Region as far as tourism is 
eoncerned, besides besto subsidies which can contribute in the implementation, intensification and expansion of the regional tourisni activity.

Key-words : Jesuit-Guarani Reductions; Consolidation of boundaries, CulturalHistorical Patrinnony; Touristie Region without boundaries; Tourism 


\section{INTRODUÇÃO}

A Região das Missões constitui-se em um espaço transfronteiriço integrado por territórios que pertencem, hoje, à Argentina, ao Brasil, ao Paraguai e ao Uruguai. Sua particularidade é dada pelo conjunto de remanescentes materiais dos "Trinta Povos das Missões" implantados na porção centro-sul da América do Sul entre os paralelos de $23^{\circ}$ e $33^{\circ}$ de latitude sul e os meridianos de $50^{\circ}$ e $59,^{\circ}$ durante o século XVII e século XVIII.

Esse conjunto de remanescentes é resultado da conquista e colonização ibérica na América do Sul e das relações conflituosas que aí se estabeleceram. Na busca da expansão e posse das terras, pelas coroas portuguesa e espanhola. Estabelecidos em território de colonização espanhola, o conjunto patrimonial das Missões encontra-se hoje, assim localizado: a noroeste do Rio Grande do Sul, no Brasil, sete povoados, na província de Misiones, na Argentina, quinze povoados e, no departamento de Itapúa, no Paraguai, oito povoados. Desse conjunto reducional são declarados pela Unesco como Patrimônio Histórico da Humanidade os sítios arqueológicas de São Miguel Arcanjo, no Brasil, São Ignácio Miní , Santa Maria, Loreto e Santa Ana na Argentina e Trinidad e Jesus no Paraguai.

Em conseqüência das grandes dificuldades econômicas pelas quais tem passado a comunidade regional, provocadas principalmente pelo fracasso de sua 
matriz produtiva baseada na monocultura, os habitantes da região que abriga os sítios das antigas reduções jesuítico-Guarani vêem no turismo uma nova opção econômica com base na originalidade de seu patrimônio.

Assim, o objeto de estudo deste trabalho é representado pelos remanescentes materiais das antigas Reduções Jesuítico-Guarani. Trata-se de uma análise da Região das Missões e as alterações impostas ao seu ambientepelo homem, nos diferentes períodos da sua evolução histórica.

Seu objetivo geral é descrever de forma explicativa os processos de ocupação da Região das Missões Jesuítico-Guarani, que contribuíram para que a mesma tenha se constituído hoje, em uma "Região Turística". Seus objetivos específicos são o de analisar a importância das Missões Jesuíticas na consolidação das fronteiras do sul do Brasil; analisar a situação dos sítios arqueológicos das antigas reduções jesuítico-Guarani; avaliar a importância dos remanescentes arquitetônicos das antigas reduções como potencial turístico; analisar os programas e projetos propostos para a Região das Missões em relação ao turismo, além de fornecer subsídios que possam contribuir para a implementação, intensificação e expansão da atividade turística regional.

Como pressupostos teóricos tem-se:

- A formação territorial do Rio Grande do Sul deu-se a partir das disputas entre as coroas de Portugal e Espanha, que se estabeleceram na América e adotaram uma política expansioniista buscando ocupar o máximo possível do território, 
pelas riquezas nele encontradas. As Missões Jesuítico-Guarani tiveram importante participação nesse contexto.

- As materialidades das antigas Reduções Jesuítico-Guarani, apontam, hoje, para um novo uso comum do território, em busca de melhores condições de vida para a comunidade regional - o desenvolvimento das atividades turísticas.

- Através de iniciativas do turismo será possível, buscar a integração econômica, via integração cultural, implantando políticas integradas que venham ao encontro do atendimento das necessidades da população regional.

Como método de investigação usou-se o método evolutivo histórico que, de acordo com Sauer (2000), permite descrever, explicar, conhecer e analisar as mudanças provocadas pela ocupação humana em uma região específica, estabelecendo as etapas das obras humanas que habitaram esta região e nela imprimiram uma expressão característica. Para tanto foram realizadas: pesquisa bibliográfica, pesquisa documental e pesquisa de campo com realização de observação direta; e entrevistas com pessoas ligadas às atividades turísticas na Região das Missões.

Em relação às fontes bibliográficas é necessário destacar o grande número de trabalhos e publicações disponíveis. No entanto, a historiografia sobre a formação do Rio Grande do Sul possui duas correntes: a de matriz platina que defende a idéia que a formação historiográfica do Rio Grande do Sul inicia a partir de 1626,quando o Padre Roque Gonzáles fundou a Redução de São Nicolau, em nome da igreja católica e da coroa espanhola, e a de matriz de ideologia lusitana 
que defende a idéia de que a formação sul-rio-grandense inicia-se em 1737, quando Silva Paes, em nome da coroa portuguesa, fundou o forte Jesus Maria José, que originou a cidade de Rio Grande, ignorando o período de colonização espanhola. Não constitui objeto de estudo deste trabalho discutir a polêmica existente entre as correntes historiográficas e sim conhecer a importância que tiveram as Missões Jesuítico-Guarani, no processo de sua formação territorial e suas repercussões atuais.

Observa-se o reduzido número de trabalhos na área de Geografia sobre a formação territorial do Rio Grande do Sul e, especificamente, sobre as Missões. Destacam-se aqui os trabalhos de Camarata (2001) Iha a questão a questão do Turismo no Depatamiento de Misiones (Argentina) no espaço transfronteiriço com Paraguai e Brasil.(1999) de Gelpi(2001) que trata da urbanização no Rio Grande do Sul fazendo, anteriormente, uma análise aprofundada da ocupação territorial do Estado(...) Como na História, muitos dos pesquisadores ignoram as Reduções Jesuíticas na formação territorial do Rio Grande do Sul como pode ser observado na obra em que Medeiros (2004) destaca que a configuração territorial do Estado é originária de duas formações socioeconômicas constituídas ao longo da história: uma na serra do sudeste e na campanha, no sudoeste do Rio Grande do Sul, caracterizada por ser a sociedade dos estancieiros, peões e escravos, produtora de charque, couros e lã em grandes propriedades, os latifúndios. Outra, na depressão central e, mais tarde, na região do planalto, constituída por imigrantes colonizadores, proprietários de minifúndios e dedicados à agricultura. Segundo a 
autora, estas formações permearam a história gaúcha desde meados do século XVIII até a primeira metade do século XX. A partir desta sua afirmação pode-se observar que a presença jesuítico-Guarani e seus conseqüentes reflexos territoriais foi completamente desconsiderada em sua análise.

O trabalho foi estruturado a partir de três capítulos: 1 Missões JesuíticoGuarani: A Formação de Uma região Transfronteiriça. 2 Missões JesuíticoGuarani e a Formação do Território Do Rio Grande Do Sul. 3 Missões JesuíticoGuarani e Desenvolvimento Regional: Um Olhar para o Futuro. Buscando responder o seguinte questionamento: Se o turismo cultural é uma das modalidades que mais atrai visitantes; se a Região das Missões tem um Patrimônio Histórico Cultural original e significativo em âmbito mundial; se existem investimentos na região através de projetos voltados para a área do turismo; por que a atividade turística não consegue ser dinamizada na região? 


\section{MISSÕES JESUÍTICO-GUARANI': A FORMAÇÃO DE UMA REGIÃO TRANSFRONTEIRIÇA}

\subsection{AS MISSÕES JESUITIICO-GUARANI}

A partir da segunda metade do século XVI (1559), com os objetivos de evangelização dos índios, da manutenção da fé dos colonos e a integração do índio ao sistema colonial espanhol foram implantadas no Continente Americano as Missões: como a da Califórnia na América do Norte; do Orinoco na América Central; de Mainas, de Mojos, de Chiquitos. De Juli e de Guairá (que se expandiu para Tape e Itatim), na América do Sul, como pode ser observado na figura 1.

Ao chegar à região centro-sul da América do Sul, entre os paralelos de $23^{\circ}$ e $33^{\circ}$ de latitude sul e os meridianos de $50^{\circ}$ e $59^{\circ}$ de longitude oeste (figura 2), os colonizadores europeus encontraram-na habitada por grupos Guarani que viviam

a sua antiga usança em serras e vales, junto de arroios escondidos, em três, quatro ou seis casas apenas, separados uns dos outros em questão de léguas duas ou três ou mais foram reduzidos conforme a diligência dos padres a povoações não pequenas e à vida política (civilizada) e humana. , (Montoya , 1985, p. 34)

\footnotetext{
${ }^{1}$ Escreve-se "Guarani" no singular e não "Guaranis" no plural pois segundo a "Convenção para a Grafia dos Nomes Tribais" assinado pelos participantes da $1^{\text {a }}$ Reunião Brasileira de Antropologia, no Rio de Janeiro em 1953, para uniformizar a maneira de escrever os nomes das sociedades indígenas em língua portuguesa: "os nomes tribais, quer usados como substantivos, que como adjetivos, não terão flexão de gênero e de número, a não ser que sejam de origem portuguesa ou morficamente aportuguesados". (DERENGOSKI, 2002, p 7) )
} 


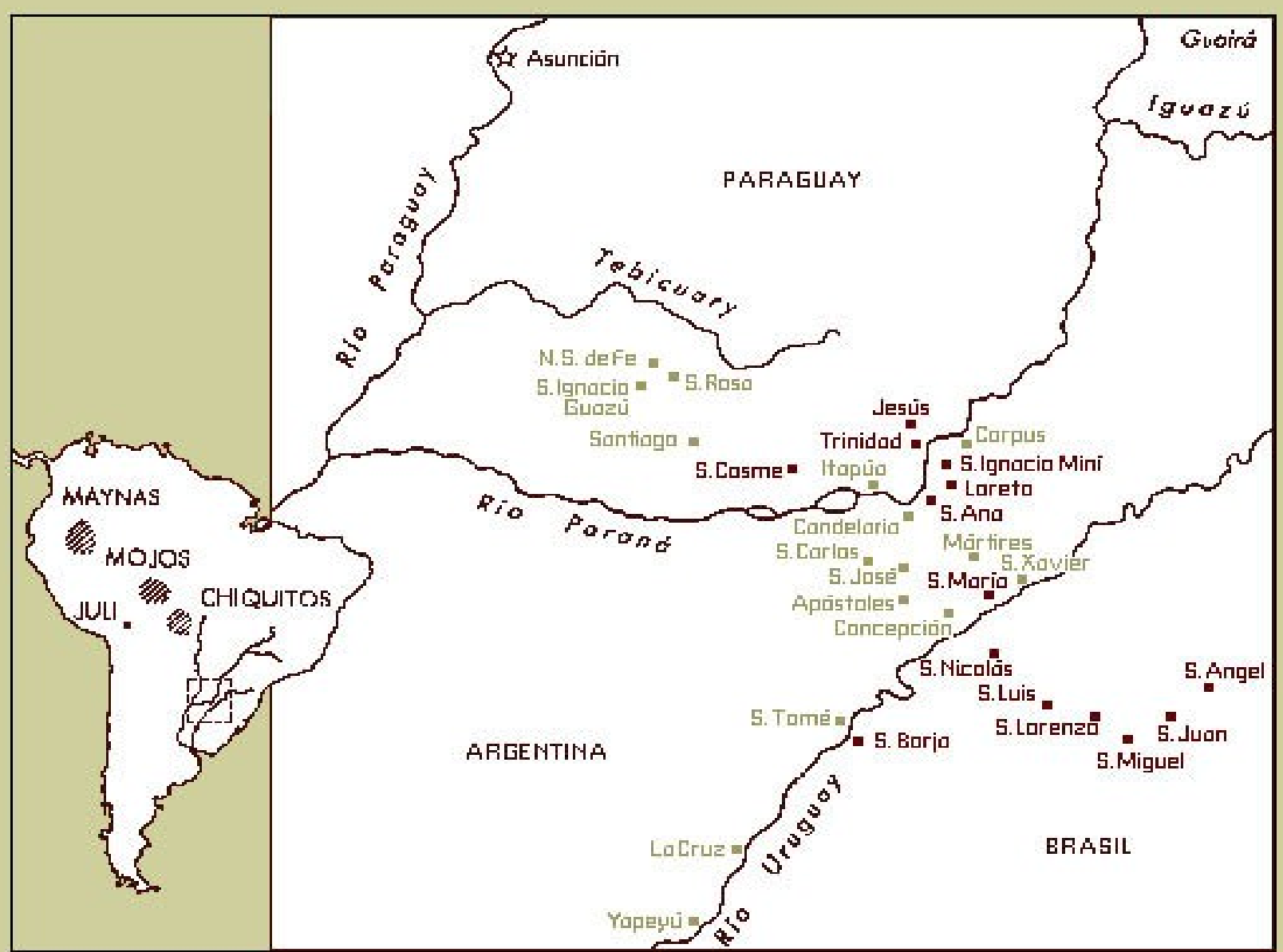

Os trinta povoados guaraníticos da Província Jesuítica do Paraguai no Século 18 Em destaque os povoados com os principais remanescentes, integrantes do Circuito

Figura 1: Mapa da Localização das Missões na América Latina Fonte: 


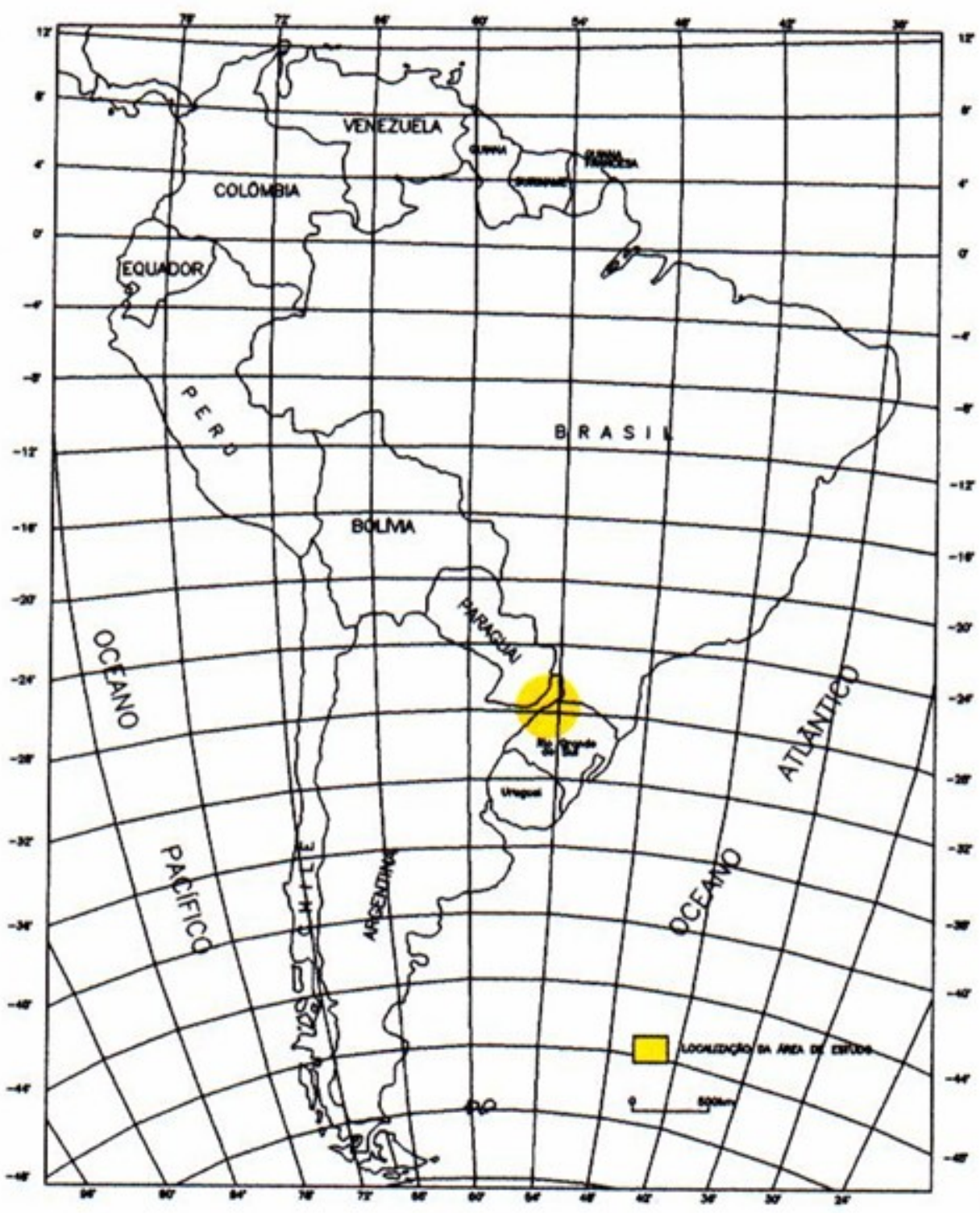

Figura 2: Mapa da localização da área de estudo Fonte: Nogueira (1999, pág. 48)

Iniciam-se, então, os contatos entre as populações indígenas e os colonizadores, através das expedições de reconhecimento. Logo em seguida, houve fixação do colonizador que implantou um sistema de exploração e subjugação sócioeconômica imposto pela "encomienda" - concessão de um certo número de índios a um colonizador branco, sob forma de tributo ou trabalho - e da captura de escravos pelos bandeirantes paulistas. 
A princípio, as missões eram "Missões Itinerantes", nas quais os missionários percorriam as aldeias guarani batizando os índios, realizando a atividade de catequização de forma "ambulante". Essa forma de evangelização não se mostrou eficiente uma vez que, após o afastamento dos missionários da aldeia, os indígenas voltavam aos costumes tradicionais. Isto provocou a implantação das "missões circulares, realizadas em espaços determinados denominados de arquipélagos. Objetivando tornar a cristianização mais efetiva. Por volta de 1580 se estabelecem as missões reducionais que constituíram-se em uma rede de povoados jesuítico-Guarani”. (CUSTÓDIO, 2006).

As missões desempenharam importante papel no processo de disputa e apropriação de terras ocidentais desencadeado pela expansão marítimo-comercial da Europa que provocou a conquista de novas terras e a formação dos impérios coloniais. Sua implantação e distribuição geográfica foi uma conseqüência da disputa pela posse das terras platinas pelos governos de Portugal e Espanha, que vinha ocorrendo desde o inicio do século XV.

Os primeiros povoados reducionais do lado Espanhol das Américas foram fundados no início do século XVII, na região do Guairá, atual oeste do Paraná e em Itatim, atual sul do Pantanal mato-grossense. Um pouco mais tarde, por volta de 1620, foram fundadas também as reduções do Tape, onde hoje se encontra o território Sul rio-grandense.(BAIOTO, QUEVEDO e NASCIMENTO 1998, p. 31).

Ao serem atacadas por bandeirantes, na região do Guairá (atual território do Paraná, Brasil), deslocaram-se para o Itatim (correspondendo hoje, a porção do 
Mato Grosso do Sul e parte no atual território do Paraguai) e, posteriormente o Tape que corresponde hoje ao território do Rio Grande do Sul no Brasil, conforme pode ser observado na figura 3.

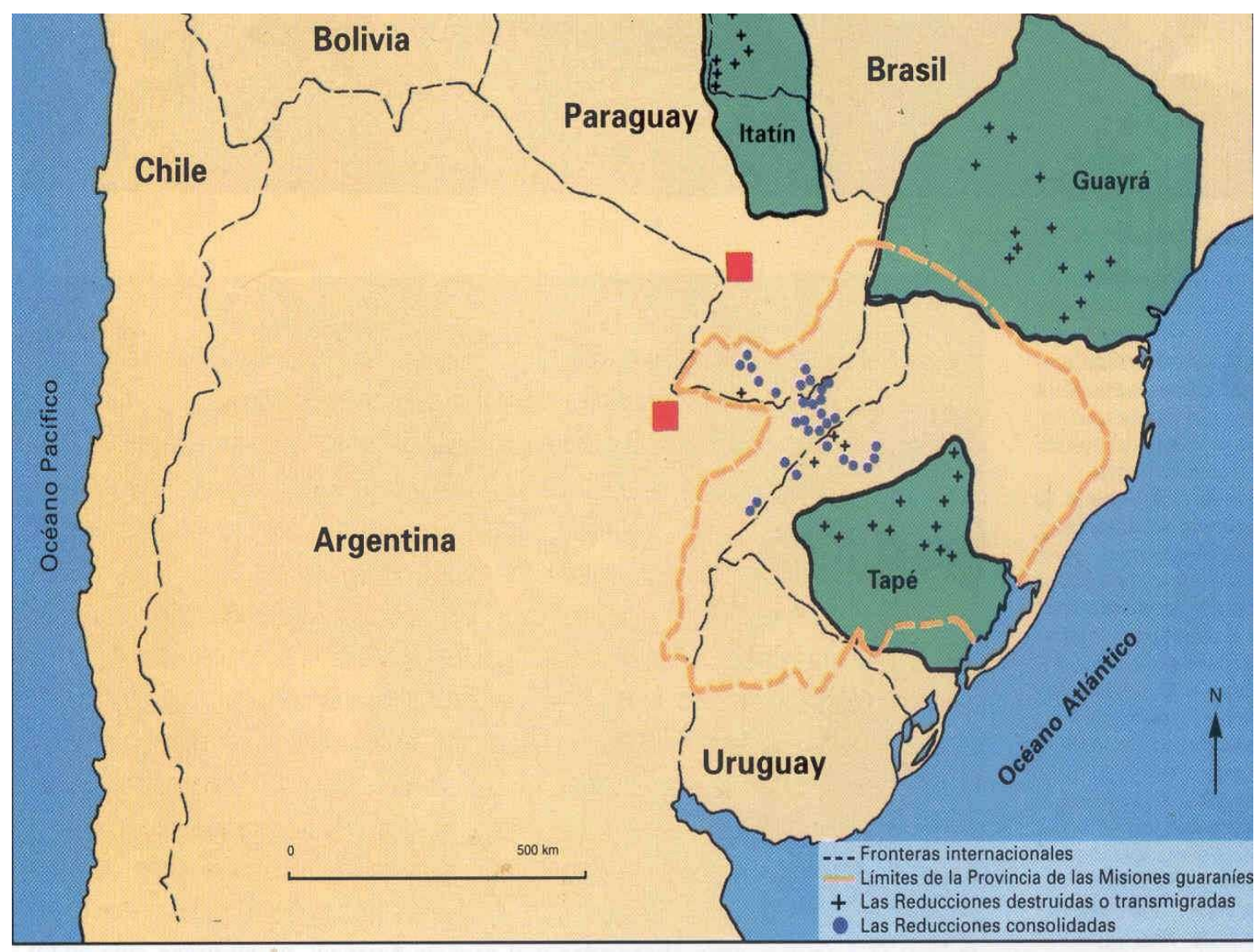

Figura 3 - Mapa da área de expansão das reduções jesuítico-guarani

Fonte: $\mathrm{ABOU}(1996$, p. 31)

Os padres jesuítas pertencentes à Companhia de Jesus prestaram grandes serviços aos estados ibéricos participando do processo de colonização na Ásia e América. A Companhia de Jesus, ordem religiosa fundada por Inácio de Loyola em 1540, num contexto mundial de grandes descobertas e aquisição de territórios pelas 
nações católicas de França, Espanha e Portugal, teve grande participação no processo de colonização. Conforme Azevedo (1984, p. 8) "em 1749, 3276 jesuítas se encontravam distribuídos em cinco continentes. Desse número, 90\% estavam trabalhando nos territórios controlados por Espanha e Portugal, nas Américas e na Ásia”.

Para Sebe

as tarefas da Companhia variavam bastante de lugar para lugar, mas podem ser agrupadas em duas áreas básicas. Na Europa, o cuidado pedagógico, nos colégios ensinando. Nas colônias, o missionarismo ${ }^{2}$ era o objetivo principal. (1982, p. 8)

Como as demais ordens que se dedicaram às missões, a Companhia de Jesus recebeu

o encargo de representar a Igreja face aos neófitos indígenas e levar a cabo este objetivo maior da salvação. Passaram a ser não só os únicos

\footnotetext{
2 Significava uma nova fase do ideal religioso da época. A propagação da fé foi motivo de movimentação de incontável número de religiosos que deixaram a Europa para em outras regiões ensinar a palavra de Deus segundo a versão cristã. O preceito evangélico "ide e ensinai o Evangelho a todos" passou a ser um desafio. (SEBE, 1982, p. 55)
} 
representantes da autoridade eclesiástica e civil, como também de toda a civilização ocidental, seus valores e tradições. (KERN 1982, p. 91)

Para o autor, a ação missionária que objetivava a evangelização e a conversão do indígena acabou assumindo uma ação político-administrativa por que:

- eram políticas as ações missionárias que colocavam os jesuítas em contato direto com os caciques locais como representantes do monarca;

- eram políticas as ações desenvolvidas pelos missionários para obter, através da vassalagem direta do monarca, que os Guarani escapassem da escravidão ao organizarem os povos reducionais;

- era política a organização das milícias indígenas equipadas com armas de fogo para fazer frente à expansão escravocrata dos bandeirantes portugueses;

- era política, também, a própria situação fronteiriça das reduções.

De acordo com Maestri o "projeto jesuítico era o mesmo para o novo mundo. Reunir em uma aldeia diversas comunidades nativas, submetê-las à autoridade colonial e convertê-las ao cristianismo e ao que consideravam civilização". (apud COLVERO 2004, pág. 18).

Afora converter os índios ao cristianismo, as missões visavam garantir a navegação pelos rios da Bacia do Prata, que era dificultada pelos índios, utilizar-se de sua mão-de-obra e apossar-se das terras devolutas. Para Simon

Além da pregação do evangelho e salvação das almas para Cristo, conforme os objetivos cristãos da Companhia de Jesus as missões traziam 
consigo a ideologia colonialista de possessão de terras e comércio de riquezas. $(2004$, p. 11$)$

As Missões Jesuíticas "caracterizam-se como uma empresa religiosa com intenção explícita de conversão dos Guarani ao cristianismo, também serviam aos interesses do colonato e da coroa" (TOCCHETTO 1991, p. 14). Através delas, foram implantadas as reduções jesuítico-Guarani locais de concentração dos índios em pequenos povoados para convertê-los à fé da Igreja Católica e sua vassalagem à coroa espanhola.

De acordo com Quevedo

As reduções eram simples povoados, com igrejas de madeira ou taipa e residências dos índios, estas geralmente feitas de pau a pique. A pedra era pouco usada porque a ação escravista das bandeiras e a hostilidade do meio impunham um caráter itinerante ao empreendimento. (2000, p. 17)

Esta estrutura de redução caracterizou a primeira fase missioneira em território hoje pertencente ao Rio Grande do Sul. Já na segunda fase, após 1682, as reduções começaram a ser construídas com arenito ou pedra grês e tijolos de adobe. Nas demais reduções, em território Paraguaio e Argentino o uso da pedra passou a ser feito a partir da metade do século XVII.

Para o autor supra citado

ao receber o missionário, o índio jamais podia imaginar que naquele instante estava abandonando seu modo de vida tribal, para assumir um 
modo de vida histórico típico da época moderna. Esta era uma transição sem precedentes na história dos povos indígenas, justificado pelos padres, que utilizavam sua concepção de mundo afirmando que era necessário converter o índio. (2000, p. 58)

A “redução foi a alternativa para o aproveitamento colonial da população indígena, integrando-a dentro do sistema, principalmente nas regiões de conflito territorial dos dois impérios ibéricos" (TOCHETTO op cit). Constituía-se também em um meio educativo privilegiado para conversão e para a prática cristã. Para os índios, entretanto, "as reduções representavam a possibilidade de não serem escravizados, tanto pelos encomenderos ${ }^{3}$ espanhóis quanto pelos luso-brasileiros de São Vicente". (COLVERO 2004, p. 20)

Muitos colonos eram contrários à ação reducional dos jesuítas que apoiavam o padroado $^{4}$ real, mas eram contra a escravização do índio que ocorreria nas encomiendas.

Esse sistema de trabalho predominava no sul do Brasil e no Paraguai. Os colonos espanhóis dessas regiões tinham o direito de explorar o trabalho das comunidades Guarani na lavoura e nas construções. Em troca, pagavam um tributo à Coroa e se comprometiam a cuidar da assistência religiosa aos nativos. (QUEVEDO, 1996, p. 8)

\footnotetext{
${ }^{3}$ encomendero:comerciante devidamente licenciado, pelos governantes espanhóis, para arrebanhar índios que teórica e arbitrariamente eram considerados sujeitos a "encomienda" - ou recrutamento compulsório-, podendo ser "encomendados", sempre que houvesse falta de mão-de-obra na comunidade. Por isso, e respaldados oficialmente, formou-se essa categoria social nos primeiros tempos das colônias hispânicas, que se dedicava à caça de índios em estado selvagem para comercializá-las no mercado de escravos. PINTO (2002, p. 98)

${ }^{4}$ padroado: permissão dada à monarquia espanhola de construir igrejas, criar paróquias e dioceses, nomear vigários e bispos a fim de organizar e consolidar a evangelização no seus domínios americanos. Com essa permissão os reis da Espanha se tornaram os "patronos" da Igreja Católica na América sendo os responsáveis pelo ensino da doutrina católica e pela conversão ao catolicismo das populações nativas. QUEVEDO (1996).
} 
Nesse contexto, no período de 1609 a 1706 foram fundadas ao longo dos rios "Paraguai, Paraná, Paranapanema e Uruguai, pelo menos um total de 48 reduções [...] sendo que apenas 30 delas chegaram a florescer e desenvolver-se como verdadeiras cidades". (Simon, 2004, pág. 20) (figura 4). Dezoito delas, as implantadas no período de 1626 a 1637 na região do Tape, não sobreviveram em conseqüência dos ataques dos Bandeirantes.

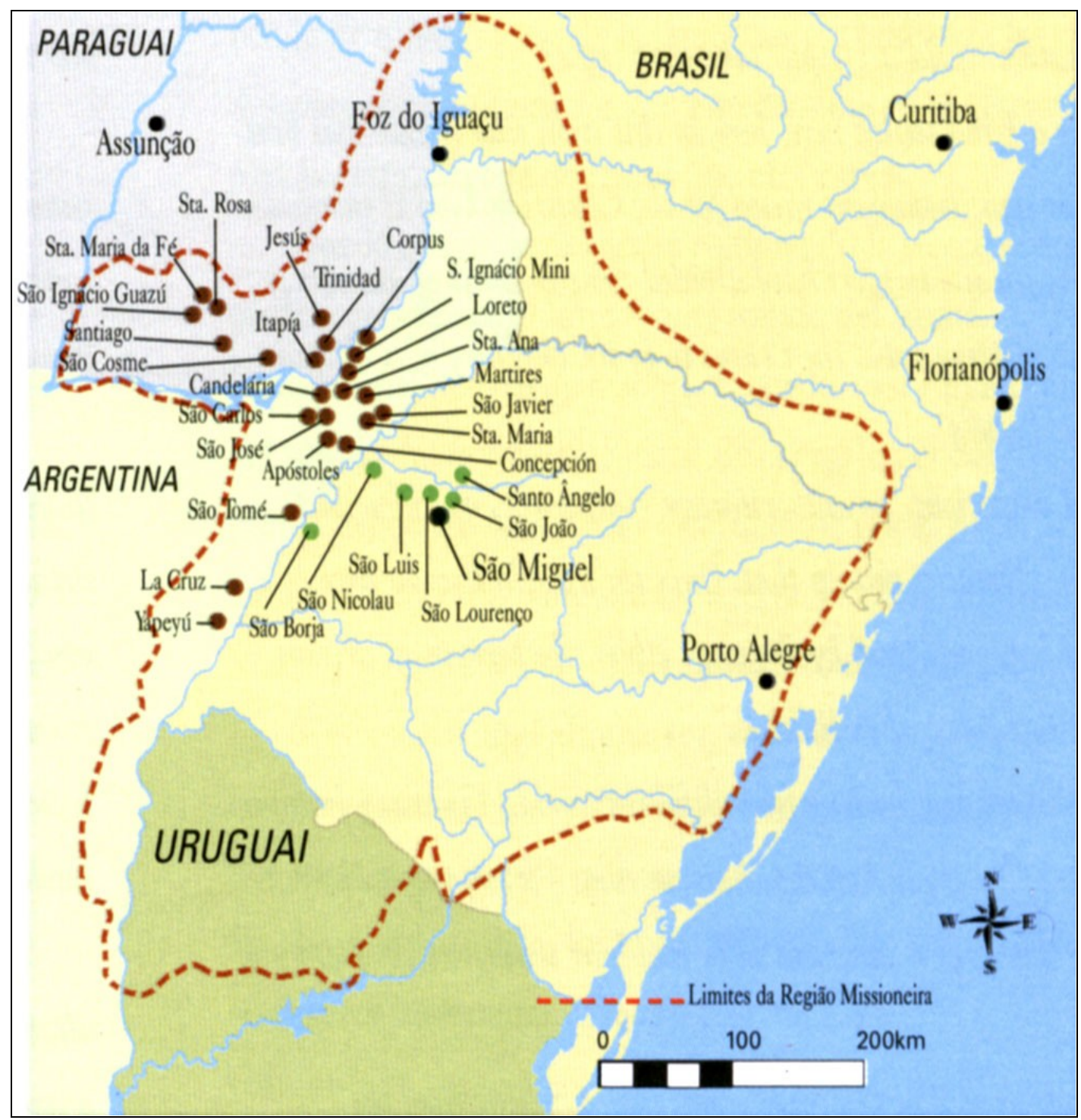


Figura 4: Mapa da localização dos 30 Povos das Missões

Fonte;http://www2.uol.com.br/mochilabrasil/missoes.shtml

Esses "Trinta Povos das Missões" originaram-se da expansão ocorrida no Itatim, Guairá e Tape (Mapa 3). Na Província Jesuítica do Paraguai ${ }^{5}$ foram implantadas, à margem direita do Rio Uruguai, as reduções que hoje encontram-se no território da Argentina e do Paraguai (Quadros 1 e 2).

\begin{tabular}{|l|l|l|}
\hline $\begin{array}{c}\text { ANO DE } \\
\text { FUNDAÇÃ }\end{array}$ & \multicolumn{1}{|c|}{ NOME } & \multicolumn{1}{|c|}{ PADRE FUNDADOR } \\
\hline 1610 & Nuestra Señora de Loreto & \\
\hline 1610 & San Ignacio Mini & José Cataldino \\
\hline 1619 & Concepción & Simão Maceta \\
\hline 1622 & Corpus Christi & Roque Gonzáles \\
\hline 1626 & Santa Maria Mayor & Pedro Romero \\
\hline 1626 & Nuestra Señora de los Reis - Yapeyú & Diego de Baroa \\
\hline 1627 & Nuestra Señora de Candelária & Pedro Romero \\
\hline 1628 & Santa Cruz & *Roque Gonzales \\
\hline 1631 & São Francisco Javier & Cristóvão Altamiro \\
\hline 1631 & Santos Apóstolos (Pedro e Paulo) & José Ordoñes \\
\hline 1631 & São Carlos Borromeo & Diego de Alfano \\
\hline 1632 & Santo Tomé Apóstol & Pedro Molas \\
\hline 1633 & Santa Ana & Luís Ernot \\
\hline 1633 & São José & Pedro Romero \\
\hline 1639 & Santos Mártires de Japón & José Cataldino \\
\hline
\end{tabular}

Figura 5: Quadro das Reduções Jesuítico-Guarani Na Argentina

${ }^{5}$ criada em 1607, pelo Pe. Cláudio Aquaviva, abrangendo territórios que hoje formam o atual Paraguai, a Argentina, o sudeste do Brasil, terras na época ocupadas pelos espanhóis. Objetivava a expansão das Missões. (Astrain apud Damini, 2004, pág 20) 
Fonte: quadro elaborado a partir de Pinto (2002) e Simon (2004)

\begin{tabular}{|l|l|l|}
\hline \multicolumn{1}{|c|}{$\begin{array}{c}\text { ANO DE } \\
\text { FUNDAÇÃo }\end{array}$} & NOME & \multicolumn{1}{c|}{ PADRE FUNDADOR } \\
\hline 1610 & São Ignácio Guazú & Marcelo de Lorenzana \\
\hline 1615 & Nuestra Señora de Encarnación de Itapuá & Roque Gonzáles \\
\hline 1632 & San Cosme y San Damián & Adriano Formoso \\
\hline 1647 & Santa Maria de la Fé & Manuel Berthod \\
\hline 1651 & Santiago & $*$ \\
\hline 1685 & Jesús & Jerônimo Delfin \\
\hline 1698 & Santa Rosa de Lima & $*$ \\
\hline 1706 & Santíssima Trinidad & João de Amaya \\
\hline
\end{tabular}

Figura 6 - Quadro das Reduções Jesuítico-Guarani No Paraguai

Fonte: quadro elaborado a partir de Pinto (2002) e Simon (2004)

* fundador não identificado

À margem esquerda do Rio Uruguai, em território hoje pertencente ao Brasil, entre os anos de 1626 e 1637, foram implantadas dezoito reduções (Quadro 3) constituíndo o que foi chamado de "Primeiro Ciclo Missioneiro no Rio Grande do Sul". 


\begin{tabular}{|c|c|c|}
\hline $\begin{array}{c}\text { ANO DE } \\
\text { FUNDAÇÃO }\end{array}$ & NOME & PADRE FUNDADOR \\
\hline 1626 & São Nicolau & Roque Gonzáles de Santa Cruz \\
\hline 1626 & São Francisco Xavier & * \\
\hline 1627 & Nossa Senhora Candelária do Ibicuí & * \\
\hline 1628 & Nossa Senhora Assunção do ljuí & João de Castillo \\
\hline 1628 & Nossa Senhora Candelária do Piratini & * \\
\hline 1628 & Todos os Santos do Caaró & Roque Gonzáles de Santa Cruz \\
\hline 1631 & Apóstolos & * \\
\hline 1631 & São Carlos & * \\
\hline 1632 & São Tomé & * \\
\hline 1632 & Natividade & * \\
\hline 1632 & São Cosme e Damião & * \\
\hline 1632 & Jesus Maria & * \\
\hline 1632 & Sant Ana & * \\
\hline 1632 & São Miguel Arcanjo & Pe. Cristóvão de Mendonza \\
\hline 1633 & São José & * \\
\hline 1634 & São Cristóvão & * \\
\hline 1634 & São Joaquim & * \\
\hline 1637 & Santa Tereza & * \\
\hline
\end{tabular}

Figura 7: Quadro das Reduções Jesuítico-Guarani No Brasil-primeiro Ciclo

Fonte: quadro elaborado a partir de Pinto (2002) e Simon (2004)

* fundador não identificado

gado, introduzido na região pelo padre Cristóvão de Mendonza em 1634, tornou-se uma "nova riqueza" disputada pelos colonizadores. Foram implantadas grandes estâncias de criação de gado bovino que representou o "fundamento 
econômico básico de apropriação da terra gaúcha através da preia de gado xucro". (PESAVENTO apud DAMIANI, 2004, p. 69)

Nesse período era constante ataque por parte dos bandeirantes ${ }^{6}$ que sentiamse prejudicados achando que os padres jesuítas disputavam com eles o controle do trabalho indígena. Para os luso-brasileiros, os jesuítas representavam uma ameaça, pois disputavam a mão-de-obra indígena que queriam escravizar enquanto "os jesuítas queriam cristianizá-los e especializados em uma profissão para autodefesa". (QUEVEDO, 1982, p. 16), Isso obrigou índios e jesuítas a retornarem para a margem direita do rio Uruguai, abandonando aquelas que constituíram o "Primeiro Ciclo Missioneiro" no atual território do Rio Grande do Sul. Conforme Kern

... devido ao crescimento demográfico e à necessidade de proteção das áreas ganadera e ervateira ameaçadas pelo avanço português, os limites orientais das Missões estenderam-se novamente, pela margem esquerda do Rio Uruguai. Ali sete povoações missioneiras foram fundadas, desde o final do século XVII até 1707. (1982, p.13)

O estabelecimento dos "Sete Povos das Missões" (Quadro 4) constitui o "Segundo Ciclo Missioneiro" em território do atual Rio Grande do Sul.

\footnotetext{
${ }^{6}$ bandeirantes: colonos paulistas que organizavam as bandeiras, expedições de captura de índios para fornecimento de mão-de-obra escrava às lavouras e às minas. (QUEVEDO 1996, p. 9)
} 


\begin{tabular}{|l|l|l|}
\hline \multicolumn{1}{|c|}{$\begin{array}{c}\text { ANO DE } \\
\text { FUNDAÇÃo }\end{array}$} & \multicolumn{1}{|c|}{ POME } & \\
\hline 1682 & São Francisco de Borja & Francisco Garcia \\
\hline 1687 & São Nicolau & Roque Gonzáles \\
\hline 1687 & São Luiz Gonzaga & Miguel Fernandez \\
\hline 1687 & São Miguel Arcanjo & * \\
\hline 1690 & São Lourenço Mártir & Bernardo de La Veja \\
\hline 1697 & São João Batista & Antonio Sepp \\
\hline 1706 & Santo Ângelo Custódio & Diogo Haze \\
\hline
\end{tabular}

Figura 8: Quadro das Reduções Jesuítico-Guarani No Brasil-Segundo Ciclo

Fonte: quadro elaborado a partir de Pinto(2002) e Simon (2004)

* fundador não identificado

\subsection{1- Estrutura Espacial de uma Redução Jesuítico-Guarani}

A localização das reduções bem como a distribuição das suas estruturas arquitetônicas era definida pela legislação vigente na época: Ordenações Filipinas ${ }^{7}$ (1573) e Lei das Índias ${ }^{8}$ (1681) que estipulavam que o espaço a ser ocupado fosse um "espaço saudável" que de acordo com Kern (2002, p.7) era "longe das baixadas inundadas onde ameaçavam as febres e as doenças em áreas ventiladas e com buenos aires" e que conforme Quevedo $(2000,66)$ "era onde seria possível a criação de animais de bom tamanho e o cultivo abundante de frutas e outras plantas de

7 Editadas por Felipe III, regulava os mais variados aspectos da organização física dos povoados indígenas e outros aspectos, como a forma mais adequada de tratamento dos índios para se conseguir sua conversão religiosa. (MARTINS, 1999, p 113)

${ }^{8}$ Legislação que definia o espaço geográfico que os colonizadores tinham de ocupar, buscando preservar os interesses da coroa espanhola sobre a América (QUEVEDO, 2000) 
valor alimentar". O lugar também teria que possuir muitas árvores que pudessem ser usadas como lenha ou material de construção.

Os jesuítas levaram em consideração ainda, alguns critérios que eram comuns à implantação das demais cidades jesuítas, dentre os quais Miorim (1975, p. 7) destaca: comunicação, estratégia fácil, proximidade das colônias espanholas, relevo de ondulações suaves, terras férteis, zonas de matas, cursos d'água (navegação pesca e abastecimento da população). Colvero evidencia, ainda, que os jesuítas

consideravam o espaço guarani na construção das reduções. [...] As missões seriam construídas nos lugares que tivessem alguma significação especial ou fossem sagradas para os Guarani, o que, por conseqüência, facilitaria o contato com os índios e a transformação do espaço já construído pela cultura Guarani em espaço reducional cristão. (2004, p.20)

As reduções apresentavam a mesma forma de organização bem como estrutura urbana semelhante (Figura 1) 'inspirado no 'plano damero' - sistema de construção das cidades hispano-americanas em que ruas paralelas centralizam para a praça". (Damiani, 2004, p. 35) De acordo com Simon:

Havia uma espécie de plano diretor único. ... O jesuíta escolhia invariavelmente um plano alto para facilitar o escoamento das águas. Feito isso, traçava o quadrilátero da praça que era sempre, o centro, para onde convergiam as ruas principais. Então escolhia o norte ou o sul para implantar a Igreja. (1987, p. 97) 
Para Kern (2002) a visão de conjunto de um povoado missioneiro JesuíticoGuarani impressiona pela regularidade e pela simetria, que traduzem a idéia de ordem perfeita e definitiva. O plano urbano, como se pode observar, na figura 9 consistia de uma praça central $(\mathrm{A})$ de quatro lados. Esta praça era cercada das casas dos índios, isoladas umas das outras, em três dos seus lados. De um outro lado ficavam a igreja $(C)$ que tem a sua direita à residência dos padres (D) e as oficinas com dois pátios $(E)$ enquanto que à sua esquerda ficava o cemitério $(F)$ e o cotiguaçu (G). Por trás do complexo cemitério-igreja-pátio, localizava-se a horta (quinta) dos padres $(\mathrm{H})$. Do outro lado da praça, em frente à Igreja, ficava o cabildo (I)

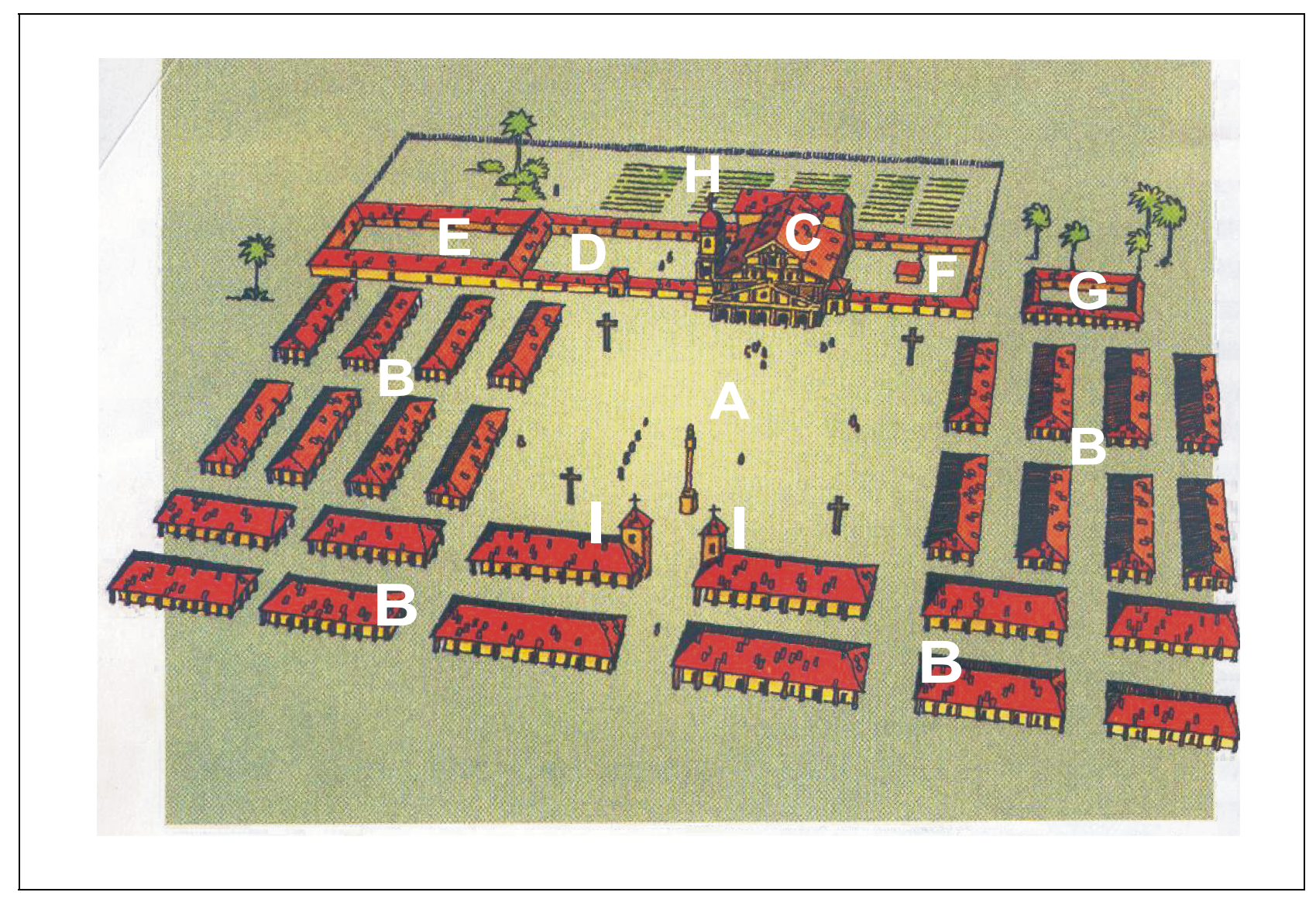

Figura 9: Desenho da Vista de uma Reduçaão 
Fonte: Adaptado de Quevedo(1996, p. 14)

No quadro que segue, pode-se identificar a função e a caracterização dos principais elementos arquitetônicos destacados na figura acima.

\begin{tabular}{|c|c|c|}
\hline ELEMENTO & FUNÇÃO & CARACTERIZAÇÃO \\
\hline PRAÇA & Fim social & $\begin{array}{l}\text { Nela se realizam jogos, danças, cantorias e procissões (Corpus } \\
\text { Christi e do padroeiro), festas, apresentação de peças teatrais, } \\
\text { casamentos coletivos e atividades militares. }\end{array}$ \\
\hline IGREJA & Profissão da fé & $\begin{array}{l}\text { Inicialmente eram pequenas "palhoças" divididas ao meio, } \\
\text { servindo de capela e moradia dos padres. Depois passaram a } \\
\text { ser "suntuosas" construções de estilo barroco-missioneiro. }\end{array}$ \\
\hline $\begin{array}{l}\text { CASA DOS } \\
\text { ÍNDIOS }\end{array}$ & Habitação & $\begin{array}{l}\text { Forma simples de habitação com espaço único que } \\
\text { desempenhava as funções de sala de estar, refeitório comedor } \\
\text { e dormitório para toda uma família. }\end{array}$ \\
\hline COTIGUAÇU & $\begin{array}{l}\text { Asilo } \\
\text { Orfanato }\end{array}$ & Abrigava viúvas, órfãos e mulheres desamparadas. \\
\hline CEMITÉRIO & $\begin{array}{l}\text { Receptório } \\
\text { de corpos }\end{array}$ & $\begin{array}{l}\text { Dividia-se em quatro seções: para homens, mulheres, rapazes } \\
\text { e meninas. Tinha o aspecto de um jardim devido aos canteiros } \\
\text { de flores. }\end{array}$ \\
\hline $\begin{array}{l}\text { CASA DOS } \\
\text { PADRES }\end{array}$ & $\begin{array}{l}\text { Habitação } \\
\text { Educação }\end{array}$ & $\begin{array}{l}\text { Era integrada por dormitórios, refeitório, cozinha, adega, } \\
\text { capela, biblioteca, colégio. Era cercada por altos muros }\end{array}$ \\
\hline TAMBO & Albergue & $\begin{array}{l}\text { Acolhia viajantes até três dias sem nenhum pagamento. Nele } \\
\text { havia o curral, um recinto fechado para o viajante e uma área } \\
\text { coberta para carretas e arreios. }\end{array}$ \\
\hline OFICINAS & $\begin{array}{l}\text { Ensinar os } \\
\text { diversos ofícios }\end{array}$ & $\begin{array}{l}\text { Eram em número de trinta a quarenta. Algumas localizadas em } \\
\text { contigüidade à residência dos padres e outras fora do povoado. } \\
\text { Pode-se destacar as oficinas de: pintura, escultura, música, } \\
\text { gráfica, olaria, padaria, ferraria, tecelagem, chapelaria, } \\
\text { carpintaria, entre outras. }\end{array}$ \\
\hline $\begin{array}{l}\text { HORTA DOS } \\
\text { PADRES } \\
\text { (QUINTA) }\end{array}$ & $\begin{array}{l}\text { Produção de } \\
\text { Alimentos }\end{array}$ & $\begin{array}{l}\text { Hortaliças e frutíferas. Nela foram introduzidas plantas exóticas } \\
\text { como a videira, o pessegueiro, a figueira, o marmeleiro, a } \\
\text { laranjeira, a romãzeira. Cultivavam ainda ervas medicinais da } \\
\text { Europa e da região bem como flores para enfeitar a igreja. }\end{array}$ \\
\hline Cabildo & Sede Administrativa & $\begin{array}{l}\text { Formada por um conselho de caciques cujo chefe maior era } \\
\text { um dos padres. Integrantes deste conselho tinham privilégios } \\
\text { como lugar na frente da igreja, maior ração de comida e } \\
\text { titulação ligada aos militares da Espanha como alcaide, alcaide } \\
\text { maior, tenente, tenente corregedor e alferes real. }\end{array}$ \\
\hline $\begin{array}{l}\text { Demais estruturas } \\
\text { (armazéns, olarias, } \\
\text { matadouros, moinhos) }\end{array}$ & $\begin{array}{l}\text { Armazenagem da produção. } \\
\text { Produção de telhas, ladrilhos } \\
\text { e tijolos. Abate de gado para } \\
\text { alimentação. Processamento } \\
\text { de grãos }\end{array}$ & $\begin{array}{l}\text { Localizavam-se fora da área urbanizada, construíam } \\
\text { importante "infra-estrutura" para o bom desenvolvimento das } \\
\text { atividades cotidianas na redução. }\end{array}$ \\
\hline
\end{tabular}

Figura 10: Quadro dos principais elementos arquitetônicos de uma redução 
No entorno do povoado eram encontrados os currais para o gado, depósitos para produtos agrícolas, fontes de água potável, olarias, armazéns, matadouros e moinhos. Já em relação ao modo de ocupação do Espaço Rural das reduções Poenitz (2004, p. 1) destaca que são desconhecidos os aspectos essenciais de como se deu esta ocupação, como se formaram as estâncias ${ }^{9}$ que se entendiam até onde hoje tem-se o território uruguaio (figura 11) e o trabalho nelas realizado, bem como as transformações operadas por elas na paisagem.

No entanto, Baioto e Quevedo (1997) destacam como principais características das estâncias missioneiras:

- Nela a propriedade da terra era coletiva e os produtos oriundos do gado pertenciam à comunidade;

- seu produto devia atender as necessidades básicas dos Guarani-missioneiros e o excedente comercializado nos mercados da zona do Prata e para Europa, e o lucro, revertia à comunidade;

\footnotetext{
${ }^{9}$ Lugar de criação de gado, com gente que realizava o rodeio e o aparte de animais doentes ou para alimentação. Os limites das estâncias eram os rios, arroios, banhados e matos. Os trechos abertos estavam vedados por valas com plantação de espinheiros ou cerca de árvores derrubadas. Nestes locais estabeleciam-se a casa do posteiro que impedia a passagem do gado. (FLORES, 1983, p. 28) As estâncias fundadas pelos jesuítas foram, na verdade, as primeiras do Rio Grande do Sul, surgiram com a introdução do gado na Banda Oriental do Uruguai, a partir de 1635, antes da formação das "vacarias". (MARQUES, 1937, p. 36) A estância diferenciava-se da "vacaria" que era o local onde o gado se criava livremente sem a interferência do homem. As vacarias surgiram a partir do gado que foi introduzido pelos jesuítas no Primeiro Ciclo Missioneiro.
} 
- não havia trabalho escravo ou encomendado, as atividades econômicas eram exercidas pelo índio reduzido que desempenhava diversas atividades profissionais como peão de estância, capataz e posteiro;

- cada povoado possuía uma patrulha volante que protegia a estância do roubo do gado, efetuada pelos tropeiros luso-brasileiros, castelhanos e índios inimigos;

- na estância surgiram as primeiras e incipientes charqueadas ${ }^{10}$ que produziam carne salgada para o consumo interno do povoado.

${ }^{10}$ Estabelecimentos onde o gado é abatido para fabricação do charque (carne de gado vacum, salgada em mantas). Saladeiro ou tablada. (NUNES, 1984, p. 107) 


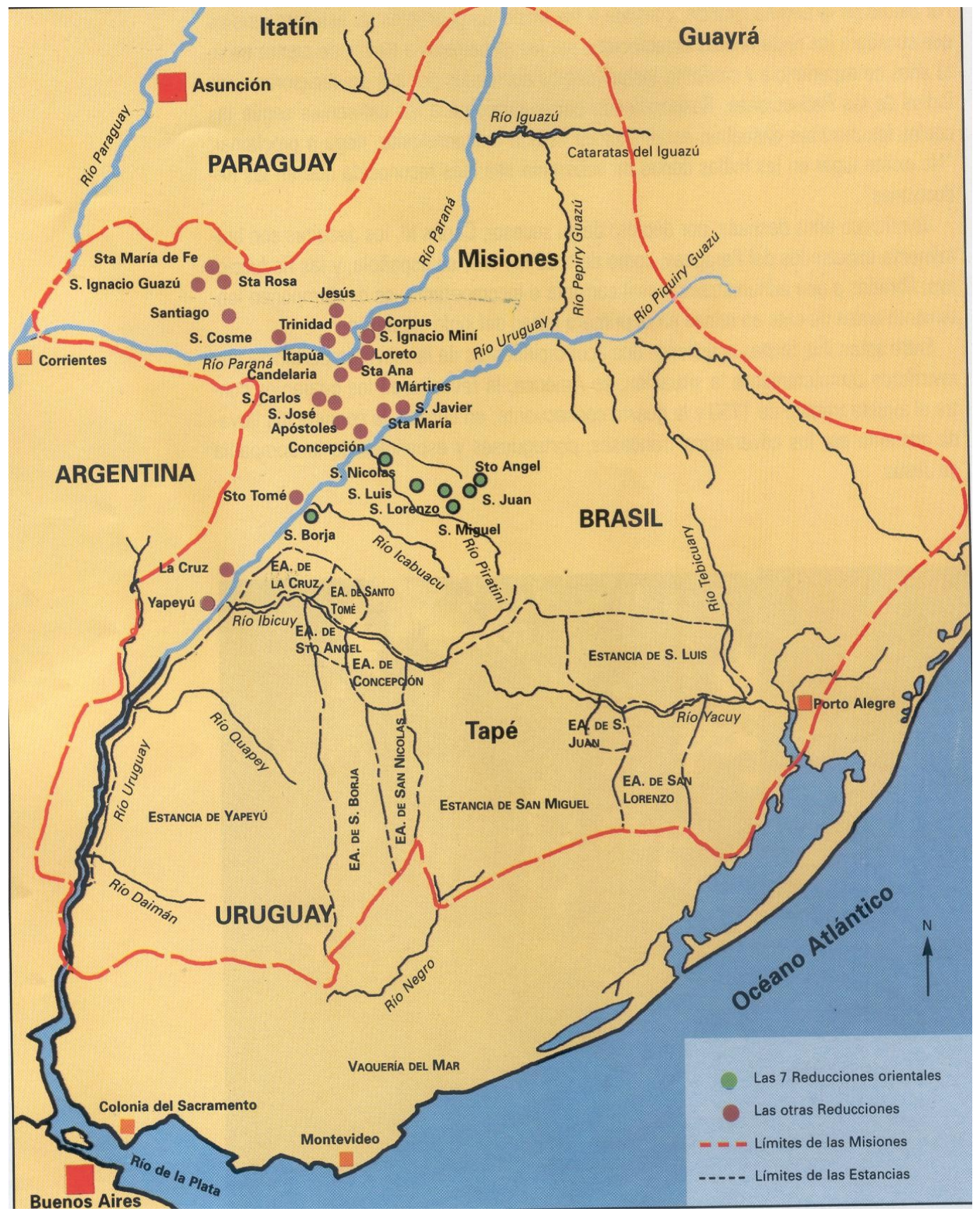

Figura 11: Mapa dos Limites das Estâncias Missioneiras

Fonte: abou (1996, p. 100)

Assim, as reduções formaram progressistas comunidades que alcançaram notável desenvolvimento econômico e cultural. Nelas o aproveitamento da terra era feito coletivamente e, paralelo ao desenvolvimento da produção agrícola (cultivo de erva-mate, algodão, milho, cevada, cana-de-açúcar, trigo, e frutas trazidas da Europa como a uva, a pêra, o marmelo, a maçã, o pêssego e a laranja, além das 
verduras e legumes) e da pecuária (criação de bovinos, eqüinos e ovinos). Desenvolvia-se a tecelagem, a fiação, a metalurgia, a arquitetura, a música, a escultura, e a aprendizagem de ofícios diversos (música, escultura, pintura, fundição entre outros).

De forma intercalada, eram realizadas as atividades de trabalho, oração, cultura e lazer, pois o ensino religioso era sistematizado e o trabalho desenvolvido por todos tinha um fim comum. (NOGUEIRA, 2001, p. 159)

Além dessas atividades, os índios missioneiros foram utilizados pelos colonizadores espanhóis para a formação das milícias ${ }^{11}$ missioneiras, que eram utilizadas no combate aos índios infiéis ${ }^{12}$ e aos bandeirantes portugueses, além da execução de obras públicas nas cidades espanholas bem como para o transporte e construção naval.

As reduções jesuítico-Guarani tiveram franco desenvolvimento até que a disputa pelas terras entre as coroas ibéricas culminou com a Guerra Guaranítica, na qual os indígenas enfrentaram forças conjuntas de Portugal e Espanha até a expulsão dos jesuítas, o que provocou a derrocada das missões.

\footnotetext{
${ }^{11}$ Correspondiam ao exército missioneiro no qual os índios eram organizados a exemplo das tropas montadas nas colônias espanholas.(BRUXEL,1987, p. 55)

${ }^{12}$ Indígenas que não aceitavam a vida cristã na redução como os Charruas e Minuanos. (FLORES 1983, p. 138)
} 
Após a expulsão dos jesuítas as reduções missioneiras foram entregues aos administradores temporais que, preocupados com seu enriquecimento pessoal, saqueavam os povoados missioneiros.

a presença dos administradores quebrou a integração comunitária da economia missioneira e pretendeu que cada um dos povoados fosse autosuficiente em todos os aspectos, com isso, desarticulou-se o sistema econômico e a decadência foi vertiginosa. (GUTIERRES 1987, p. 48)

Esse fato, aliado a substituição dos jesuítas por outras ordens religiosas, a ocorrência de epidemias, a ocorrência de miséria e fome provocou grandes alterações na vida dos povoados tendo como conseqüência a fuga dos índios para os povoados espanhóis ou portugueses onde ingressaram no mercado por suas capacidades artesanais, ou empregavam-se como peões de chácaras e estâncias provocando a decadência das Missões Jesuítico-Guarani. Para Souza

\footnotetext{
...as missões de Guarani foram destruídas pelos interesses das sociedades coloniais em expansão, segundo política explicita das Coroas Ibéricas no sentido de ocupar e explorar o território e recursos outrora missioneiros. $\mathrm{O}$ fim delas liberou o vasto território a ocupação gradativa por levas sucessivas de imigrantes e degredados, trazidas desde a Europa e África. As nações surgidas ai continuaram o cerco de extermínio e marginalização das minorias indígenas, arredias o tanto quanto possível, tornadas miseráveis ou limitadas a aldeamentos restritivos. Um status social desqualificado, somente equiparável aos dos negros e marginais. (SOUZA, 1994, p. 449)
}

Hoje o grupo Guarani está presente no Brasil, na Argentina, na Bolívia, no Paraguai e no Uruguai. Conforme o Instituo Socioambiental (ISA, 2006), no Brasil 
integram 34.000 habitantes localizados no Rio Grande do Sul, Paraná, São Paulo, Rio de Janeiro e Mato Grosso, distribuídos nos subgrupos : Nandeva (8.000 a 10.000) Kaiowa (18.000 a 20.000) e Mbya (5000 a 6000). No Paraguai são em número de 21.000 distribuídos nos subgrupos: Pai Tavyterã/Kaiowa (9.000), Nandeva 7.000 e Mbya 5.000. Na Argentina, são em torno de 4.000, do subgrupo Mbya.

Em relação à comunidade indígena presente atualmente na Região das Missões, predomina os M'bya-Guarani com aldeamentos principalmente em Corrientes e Misiones na Argentina, Itapua no Paraguai e em São Miguel das Missões no Rio Grande do Sul. De modo geral, enfrentam problemas relativos a habitação, alimentação, saúde, educação, não tendo garantido o atendimento de suas necessidades básicas o que é testemunhado pelas palavras dos xamãs

Pa'i Antonio Martínez: “Las tradiciones transmitidas por nuestros antepasados no nos han permitido vivir felices por largo tiempo en lá selva: hoy ya no son suficientes para hacer felices a nuestros hijos y nietos. Lá selva retrocede, los colonos la desmontam $y$, para vivir, nos vemos obligados a trabajar para ellos.

Pa'í Cansiro Benítez:" No tenemos pueblos, vivimos al borde de la ruta. No queremos más ser explotados por los colonos y los turistas. Queremos una tierra nuestra, casas nuestras, herramientas nuestras, para trabajar la tierra y vivir de sus productos". (ABOU, 1986, p. 144)

Estes depoimentos atestam a contrastante realidade de vida dos Guarani de hoje com a pujança e o desenvolvimento dos antigos povos missioneiros.

No Município de São Miguel das Missões, no Rio Grande do Sul, radicaramse no ano de 1989 um grupo de M'bya-Guarani originados da Argentina. Fixaram-se, 
por oito anos, junto à fonte da antiga Redução de São Miguel Arcanjo. No ano de 2001 foram assentados em uma área de 236,6 há adquiridos pelo governo do Estado do Rio Grande do Sul, nas margens do Rio Inhacapetum. Vivem em condições precárias, com sérios problemas de desnutrição e saúde. Cultivam milho, mandioca, cana-de-açúcar, abóbora, melancia e batata-doce. Sobrevivem da venda de artesanato em madeira para os turistas que visitam o sítio de São Miguel.

Além das condições de extrema pobreza e abandono, a condição de total ignorância sobre suas raízes e sua história é entristecedora, pois ocupam os remanescentes da antiga redução de São Miguel Arcanjo para vender seu artesanato, aos turistas, mas desconhecem totalmente o que aconteceu com seus antepassados, que justifica a visitação ao sítio arqueológico.

\subsection{A FORMAÇÃO DE UMA REGIÃO TRANSFRONTEIRIÇA}

Implantadas em uma região que, segundo Kuhn (2002, p. 27) constituía-se em uma "fronteira em movimento, com intensa circulação de homens e mercadorias, em um contexto demográfico heterogêneo e uma conjuntura de instabilidade política" as missões ocupavam uma área que se estendia

basicamente pelos vales do Rio Uruguai e do Rio Paraná. Entretanto as atividades econômicas relacionadas ao gado e à erva-mate podiam estender-se ainda mais longe, desde os vales dos rios Negro, Jaguarão e Jacuí, e os campos de Vacaria, ao sul e ao leste, chegando mesmo até o salto das Sete Quedas, ao norte. (KERN, 1982, p. 13) 
Para o autor, a bacia do Prata durante a época colonial foi uma imensa área fronteiriça, uma "terra de ninguém" onde se realizaram as miscigenações e as sínteses culturais que geraram as populações da Argentina, do Uruguai, do Paraguai e do Rio Grande do Sul, atuais a partir de uma origem histórica comum tanto ibérica quanto indígena. (KERN, 2002)

O vasto e complexo conjunto de elementos comuns e principalmente, o longo passado compartilhado, que é testemunhado por um riquíssimo conjunto de remanescentes arquitetônicos, conferem singularidade a este espaço, conhecido hoje como "Região das Missões Jesuítica-Guarani" ou simplesmente "Região Missioneira ou Região das Missões".

O termo região se presta a inúmeras abordagens sendo que para Andrade (1976, p. 9) "seu conceito é profundamente variável entre os estudiosos de especializações diversas da ocupação do espaço". Assim,

embora seja difícil estabelecer com precisão o significado da palavra região, é certo que, seja qual for sua definição, está intimamente ligada às formas de produção que vigoram em determinado momento histórico (LEITE, 1991, p. 14)

sendo necessário, portanto, a modificação de sua conceituação em função dos avanços técnicos científicos e culturais incorporados ao processo de produção. Então, os múltiplos conceitos de região que têm sido trabalhados ao longo dos anos, por vários autores, com diferentes abordagens 
podem ser utilizados, uma vez que todos eles são meios para se conhecer a realidade, quer num aspecto espacial específico, quer numa dimensão totalizante. No entanto, é necessário que explicitemos o que estamos querendo e tenhamos um quadro territorial adequado aos nossos propósitos. (CORREA, 1987, p. 23).

O essencial, no entanto, de acordo com Britto (1986, p. 28) é "isolar constantes que possam por em relevo as grandes regularidades, segundo os objetivos visados ou a natureza da realidade a ser aprendida". Já para Wagner e Mikensel (2000) a região é a base geográfica comum com características culturais específicas habitada por comunidades humanas de se comunicam de forma regular e compartilhada e, por isso, apresentam características culturais específicas que são expressas nos seus aspectos ambientais.

É nesse sentido último que será analisada a Região das Missões que hoje, constitui-se em um espaço supranacional, integrado por territórios pertencentes à Argentina, ao Brasil e ao Paraguai, cuja particularidade é dada pelos sistemas de ações das comunidades que aí viveram e ao uso que deram ao seu território no decorrer de um processo histórico compartilhado. Possui todos os elementos que Rolim (2004, p. 8) considera como fundamental para caracterizar uma região, numa perspectiva contemporânea: "existência de diferentes grupos sociais; identificação com o território; interesse coletivo mínimo acima das disputas cotidianas; possibilidade concreta de construir um projeto político regional." $\mathrm{O}$ autor considera a região como resultante de um processo de construção social onde uma 
determinada sociedade interagindo com o meio natural constrói um particular subsistema social. Ela não é apenas território habitado, mas sim um espaço social.

Por ser uma região transfronteiriça, que, de acordo com Reigado "são as áreas contíguas à linha de fronteira de dois ou mais estados nacionais por ela separados" (apud ROLIM, 2004, p. 2), essas regiões são caracterizadas pelo fato de que nestes locais,

ao mesmo tempo que se cria um espaço econômico comum também se cria as barreiras à sua integração. Da mesma forma que se estabelecem as condições para o fluxo de pessoas e de capitais também se estabelecem as restrições para que isso aconteça. Ao mesmo tempo em que se desenvolve uma cultura comum também se arraigam as diferenças culturais. (ROLIM, 2004, p. 2).

Nelas se estabelecem contatos externos e alguma forma de cooperação entre autoridades públicas e instituições ao nível regional representadas principalmente pelas universidades, pelas empresas, pelas câmaras de comércio e indústria e organizações culturais. Existem diferentes motivos para o desenvolvimento de cooperação nas regiões transfronteiriças dentre os quais pode-se destacar:

os transportes e comunicações, condições culturais e problemas ambientais. Infra-estruturas, proteção ambiental e intercâmbio cultural encontram-se no seio de áreas que têm dado prioridade a uma cooperação além fronteiras. Outra área como a investigação e desenvolvimento, o turismo e a educação são igualmente itens que podem possibilitar uma cooperação nestes moldes. (MATIAS, 2006) 
Para o autor, o problema econômico é um forte motivo para a cooperação regional porque de modo geral, estas áreas encontram-se distantes do centro de poder, apresentando-se menos desenvolvidas que as áreas centrais. Nesse sentido a cooperação facilita seu planejamento físico e econômico criando condições para o desenvolvimento.

Assim, essa região integrada por territórios de diferentes países, envolve questões inerentes a esta condição como as de fronteiras, limites e divisas.

....A compreensão da relação entre fronteira e limites é imprescindível no estudo particular das áreas entre países limítrofes. O caráter aberto e desafiador da fronteira contrastam com a necessidade de precisão do limite, que precisa estar obviamente demarcado na topografia como artificialidade inserida pelo Estado Político. (GOLIM, 2002, p. 14)

O limite, reconhecido como linha divisória entre estados limítrofes, constituise em um

fator de separação, pois separa unidades políticas soberanas e permanece como um obstáculo fixo, não importando a presença de certos fatores comuns, físico-geográfico ou culturais". (MACHADO apud GOLIN, 2002, p. 11)

Para Martin (1998) o limite aparece como uma linha puramente imaginária, marcada na superfície terrestre por objetos naturais ou artificiais. Para o autor a divisa é o limite que se apóia geralmente em cursos de água, cristas montanhosas, coordenadas geográficas ou outras linhas geodésicas. 
Ao contrário do limite que "está orientado para dentro, a fronteira está orientada para fora" (MACHADO apud GOLIN, p. 16) e ocupa uma "uma área faixa que constitui uma zona, muitas vezes bastante povoada onde os habitantes de Estados vizinhos podem desenvolver intenso intercâmbio.... " (MARTIN 1998, p. 47)

Já para Moraes (2002, p. 95) as fronteiras "são construções históricas que possuem vários pressupostos, entre eles a constituição dos estados" enquanto que, para Castro, no mundo contemporâneo a fronteira formal não é a única:

identificam-se outras organizações sociais, econômicas, políticas, culturais e ambientais que limitam mais que a fronteira formal constituindo diferentes configurações espaciais, não só a nível local ou regional, mas em escala planetária. (2000, pág. 42)

Nesse contexto, a demarcação e fixação da linha divisória deste que hoje se constitui em um espaço transfronteiriço, apesar das operações concretamente regionais, dependeram das "decisões acordadas nos centros de decisões do poder, a exemplo do Rio de Janeiro, Lisboa, Madrid, Londres, Buenos Aires e Montevidéu" (GOLIN, 2002, p. 14), expressados no diversos tratados que se estabeleceram com a finalidade de conciliar interesses portugueses e espanhóis na América porque a expansão portuguesa no sul do Brasil ameaçava gravemente os interesses espanhóis especialmente porque as mercadorias deixaram de passar pelos portos autorizados, prejudicando seriamente a economia espanhola. Para tentar solucionar o problema, Portugal e Espanha assinaram tratados como o de Madrid (1750), El Pardo (1761), Paris (1763), Santo Ildefonso (1777) e Badajós (1801). 
1.2.1 Tratado de Tordesilhas (1494): Assinado em 1494 pelos monarcas ibéricos, dividia as terras descobertas ou que viessem a ser descobertas. Estabeleceu que as terras situadas à oeste do meridiano traçado a 370 léguas a oeste Cabo Verde, pertenciam à Espanha e, as localizadas a leste, pertenciam a Portugal. Coube a Portugal, na América, uma estreita faixa de terras delimitada pelo Oceano Atlântico (Figura 12). O alargamento desta faixa de terra pertencente a Portugal se deu principalmente pela ação dos bandeirantes, que tinham por objetivo encontrar minas de ouro e pedras preciosas; populações autóctones organizadas que pudessem ser utilizadas como mão-de-obra; ou ainda, condições naturais que possibilitassem o cultivo tropical. Esse tratado constituía-se numa atitude inovadora à época moderna, visto que resolvia os problemas políticos e econômicos das nações ibéricas em expansão marítimo-comercial. (BAIOTO, QUEVEDO E NASCIMENTO, 1998, pág. 14) De acordo com este Tratado a Região das Missões, como a maior parte do território brasileiro atual, pertencia à Espanha como todo o território brasileiro atual. 


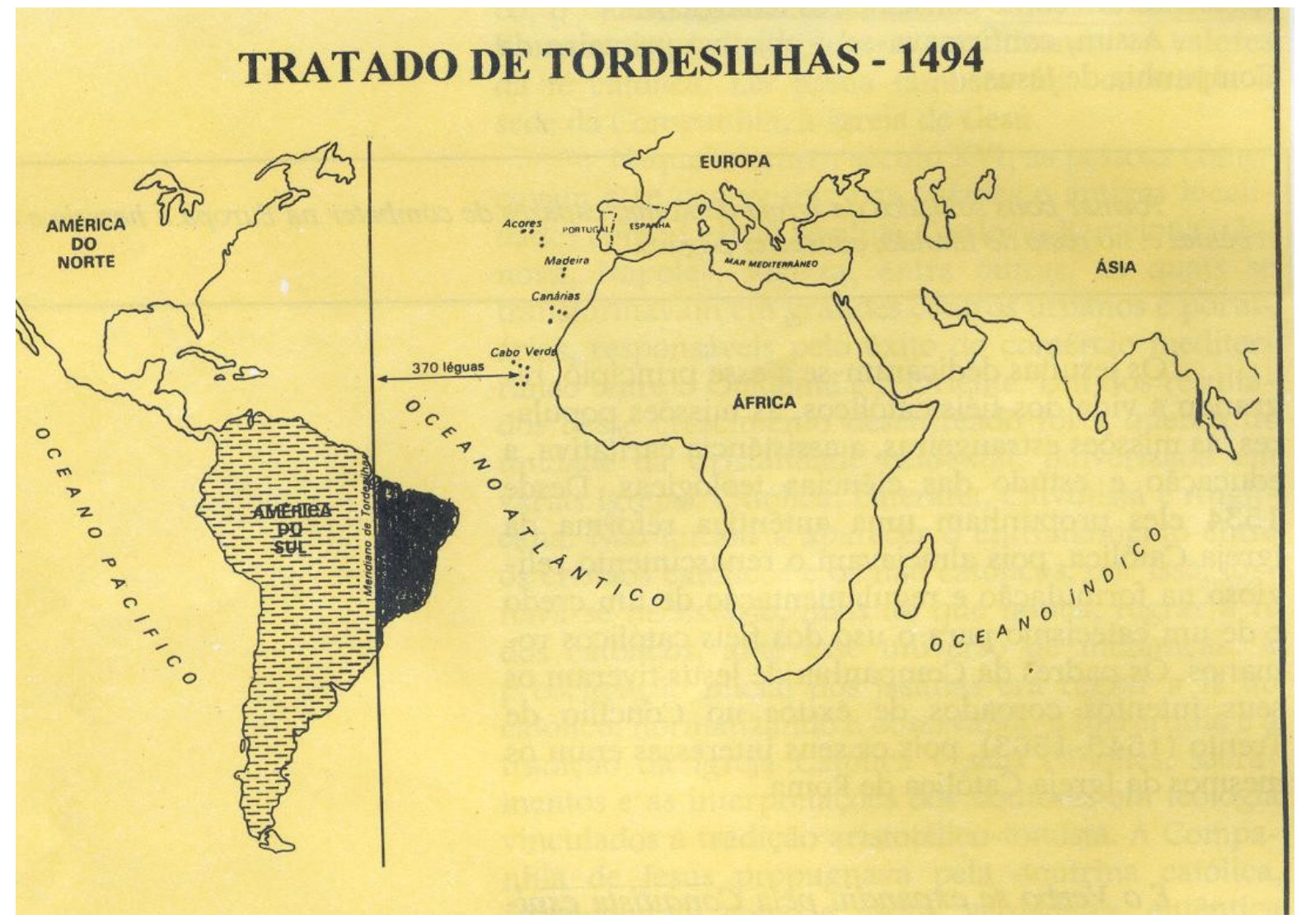

Figura 12; Mapa do Tratado de Tordesilhas

Fonte: Baioto, Quevedo e Nascimento (1998)

1.2.2 Tratado de Madrid: redefiniu as fronteiras entre Portugal e Espanha em seus domínios coloniais na América. Através deste tratado respeitava-se o princípio do uti possidetis $^{13}$. Ficou estabelecido que o território dos Sete Povos das Missões, pertencente à Espanha, seria trocado pela Colônia de Sacramento que localizava-se a $34^{\circ} 28^{\prime}$ de latitude sul e $57^{\circ} 51^{\prime}$ de longitude oeste, à margem esquerda do Rio da Prata, em frente à cidade de Buenos Aires, na margem oposta do rio. e que

\footnotetext{
${ }^{13}$ Princípio que defendia a idéia de que o direito do território deveria pertencer àquele que o povoara, que o conquistara aos primitivos habitantes.(CASTRO, 2000, p. 47)
} 
pertencia a Portugal. Além disso, por este Tratado ficavam sob a soberania de Portugal todos os territórios por ele ocupados no Amazonas e no Mato Grosso, passando o Brasil a ter uma configuração muito próxima à sua atual delimitação territorial (figura 13).

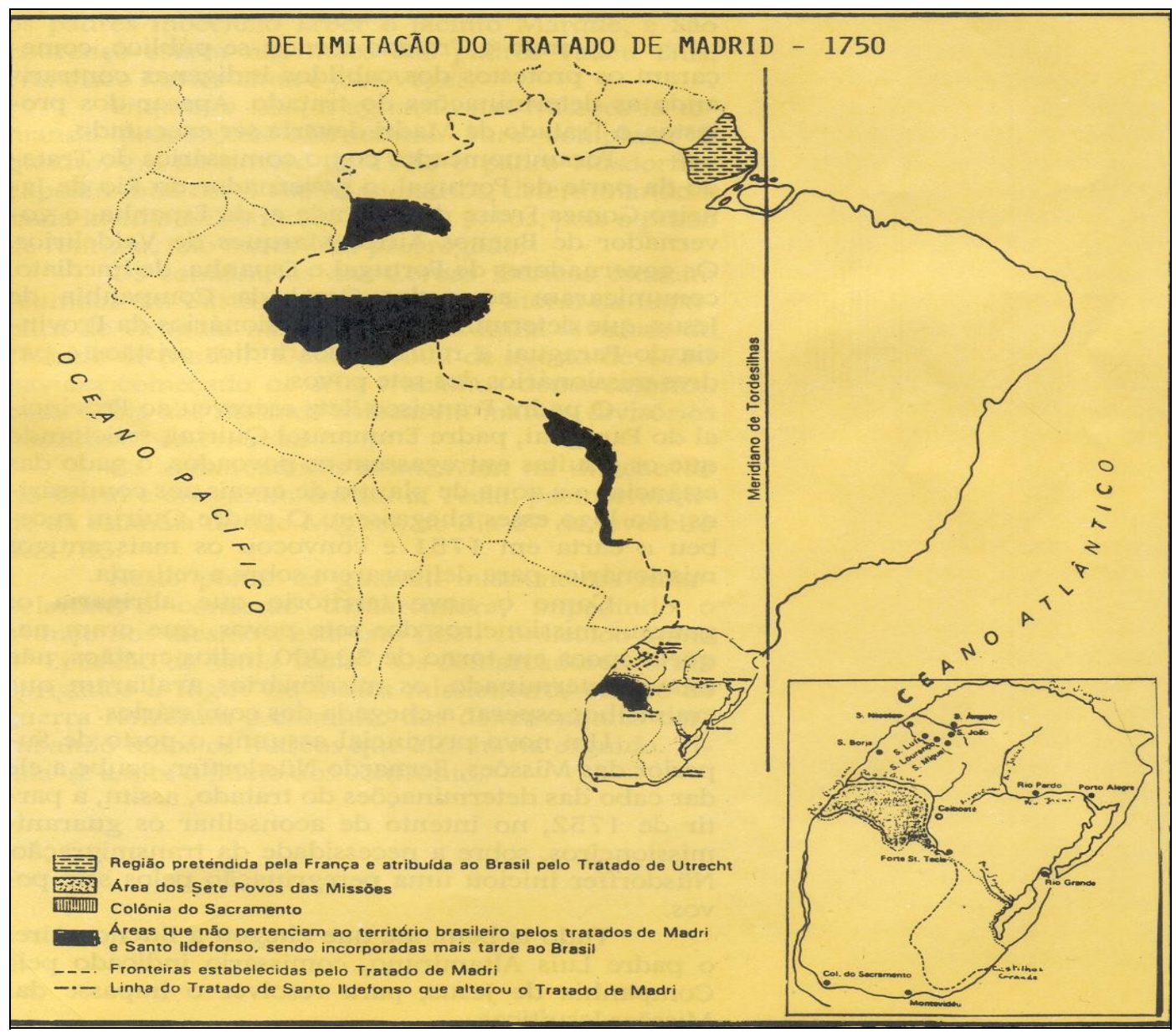

Figura 13: Mapa do Tratado de Madrid Fonte: Baioto, Quevedo e Nascimento (1998)

O acordo proposto pelo tratado de Madrid atendia aos interesses de Portugal e Espanha porque: Portugal deixava de ter interesse na Colônia de Sacramento, pois ela só proporcionava vantagens aos ingleses que a usavam para 
fazer contrabando no Prata. Para a coroa espanhola, as missões já não tinham a mesma importância do começo do século XVII porque o desenvolvimento da tecnologia militar anulava sua utilidade militar; o crescimento econômico e demográfico da colônia platina já permitia dispensar o concurso dos missioneiros; porque era motivo de apreensão para a coroa a crescente autonomia dos mesmos, traduzida na recusa de pagar o dízimo e a prestação de serviços militares estranhos aos interesses dos índios. (Freitas, 1999)

Nesse contexto, o Tratado de Madrid desencadeou uma crise nas relações entre a coroa e as Missões uma vez que suas decisões não atendiam aos interesses do índio reduzido.

Os novos limites redefiniram o espaço físico e o papel político das missões na fronteira luso-espanhola; as missões deixariam de ser guardiãs da fronteira espanhola; muitos povoados seriam extintos e milhares de índios teriam de ser removidos para a outra margem do Rio Uruguai, perdendo muito seu patrimônio: terras, plantações, estâncias de gado. Além disso, no outro lado do Rio Uruguai já havia um grande número de povoados, e os campos disponíveis eram poucos. (QUEVEDO, 1999, p. 20)

Como conseqüência da insatisfação de jesuítas e Guarani com o acordo do Tratado, no período de 1754 a 1756 ocorreu a Guerra Guaranítica na qual os índios Guarani rebelaram-se. Recusando-se a deixar suas terras e a se transferir para a margem direita do Rio Uruguai conforme ficara acertado entre Portugal e Espanha, os líderes Guarani resistiram aos trabalhos de demarcação de fronteiras. Em resposta a esta atitude, as autoridades enviaram tropas portuguesas e espanholas para combatê-los. Sucederam-se batalhas nas quais os Guarani tentaram vencer os inimigos valendo-se das lutas de guerrilhas, utilizando como armas somente flechas 
e espingardas. No entanto, a bravura e determinação com que lutavam os Guarani não foi suficiente para combater a supremacia das forças da cavalaria e artilharia portuguesa e espanhola. Assim, os índios Guarani foram dizimados e os padres jesuítas expulsos em 1767, retirando-se das reduções em 1768. A partir daí, iniciouse a decadência das reduções que passaram a ser governadas pela administração civil colonial.

Em relação ao território das Missões, como pode ser visto na figura 13, o Tratado de Madrid eliminou os rígidos limites impostos pelo Tratado de Tordesilhas de 1494. Assim, cada reino conservaria as terras que já tivesse ocupado na fronteira uma exceção: a Espanha ficava com a Colônia de Sacramento e em troca Portugal receberia o território das Missões, ficando com os portugueses a maior parte do território do atual Rio Grande do Sul, como pode ser visto na figura 14. 


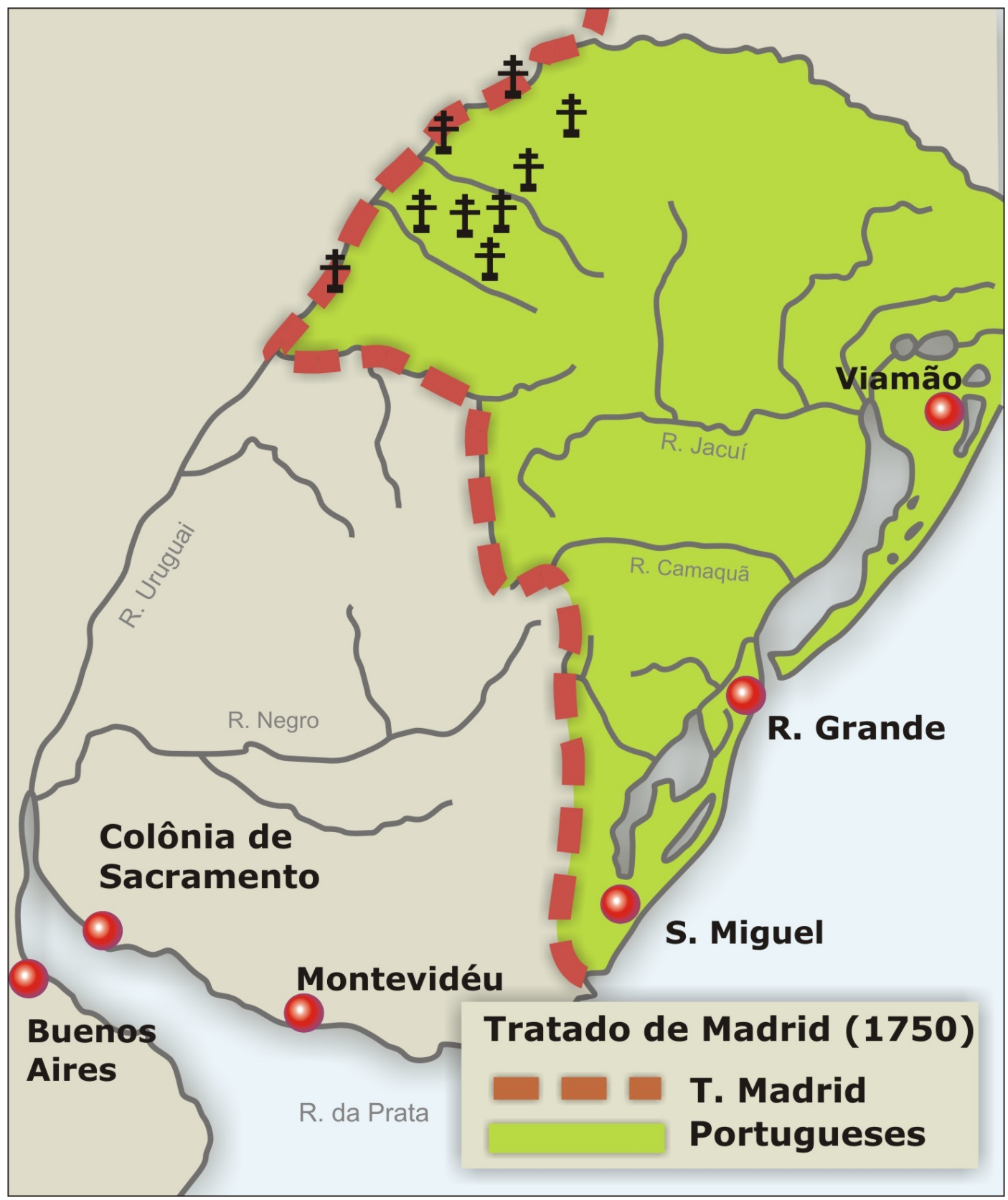

Figura 14: Mapa do Tratado de Madrid

Fonte: adaptado de Costa, Fonseca e Scmitti (2004, p. 82)

1.2.3 Tratado de El Pardo (1761): anulou o Tratado de Madrid e com isto, a Colônia de Sacramento deveria ficar com Portugal enquanto os Sete Povos voltariam para a Espanha. Entretanto este tratado não foi cumprido e os espanhóis invadiram a 
Colônia de Sacramento, Santa Catarina a cidade de Rio Grande e grande parte do atual Rio Grande do Sul.

1.2.4 Tratado de Paris (1763). Procurou resolver as animosidades surgidas em função do não cumprimento do tratado de El Pardo. A partir deste Tratado, foi convencionado uma linha de fronteira que passava pelo centro do atual Estado do Rio Grande do Sul. Esta linha limitou o território português à margem esquerda do Rio Jacuí, em direção nordeste, passando pelos Campos da Serra Geral, incluindo também o litoral, a partir de desde São José do Norte, ao norte de Rio Grande. Todo território para o sul e para o oeste incluindo também, a Região dos Campos do Sul, Colônia de Sacramento, Montevidéu, além da Região das Missões ficaram com a Espanha, conforme pode ser observado na figura 15. 


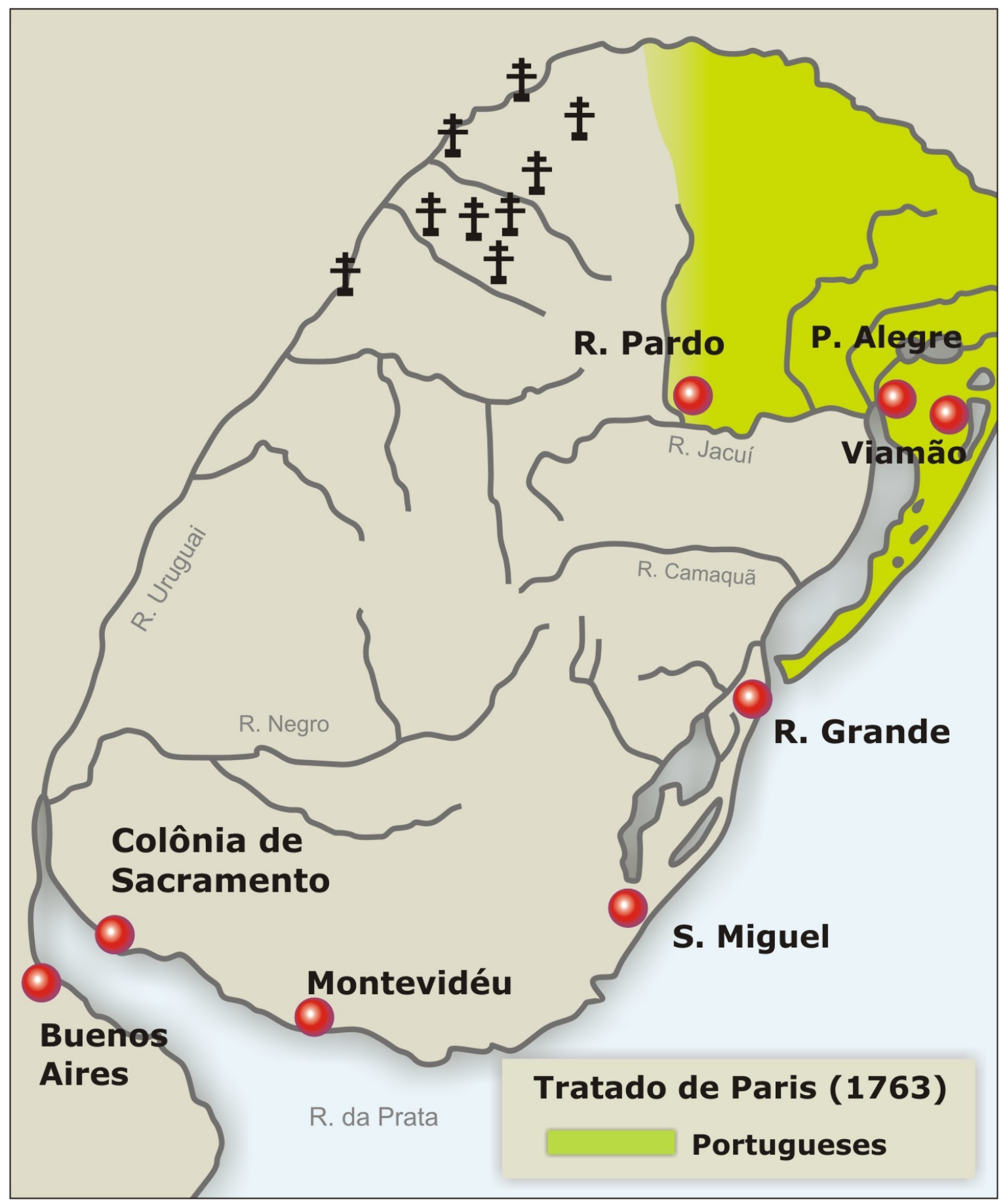

Figura 15: Mapa do Tratado de Paris

Fonte: adaptado de Costa, Fonseca e Scmitti (2004, p. 82)

1.2.5 Tratado de Santo Ildefonso (1777): foi assinado porque as desavenças entre portugueses e espanhóis não haviam se resolvido definitivamente pelo Tratado de 
Paris. Definiu os novos limites das terras entre Portugal e Espanha. A Espanha devolveu para Portugal a llha de Santa Catarina e a cidade de Rio Grande ficando com os Sete Povos das Missões e a Colônia de Sacramento. Este tratado instituí os "campos neutrais" ou "zona neutra" que se estendia ao longo da linha divisória (figura 16) que não seria ocupada por nenhuma das nações ibéricas. Na prática o acordo valeu apenas para a faixa de terras entre o Chuí e o Taim, Lagoas Mirim e Mangueira e a costa. Os portugueses não respeitaram o acordo e distribuíram sesmarias nas "áreas neutrais". 


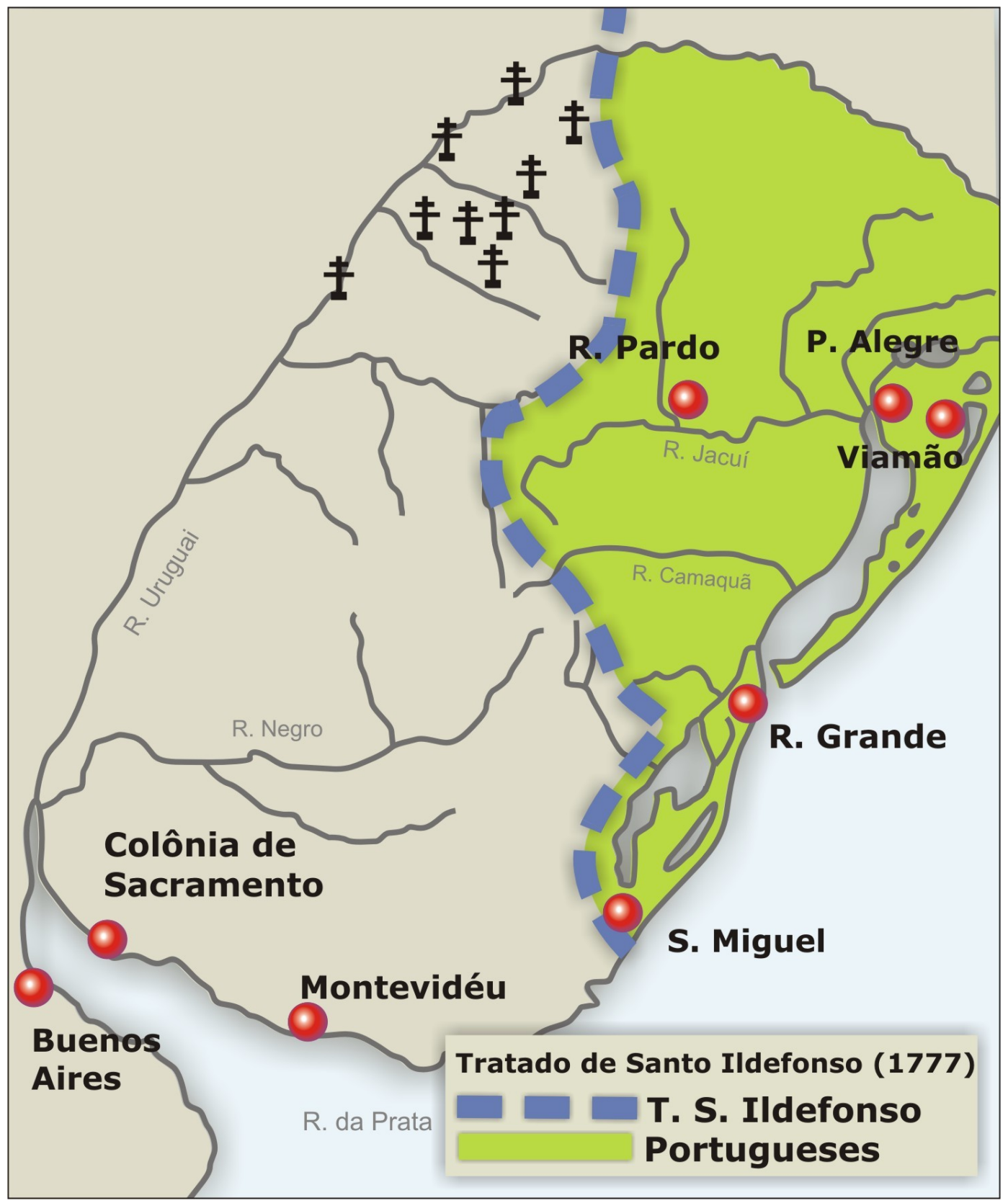

Figura 16: Mapa do Tratado de Santo Ildefonso

Fonte: adaptado de Costa, Fonseca e Scmitti (2004, p. 82)

1.2.6 Tratado de Badajós (1801): Restabeleceu as decisões do Tratado de Madrid. Pelo princípio do uti possidetis foram incorporados definitivamente ao Brasil o 
territórios dos Sete Povos das Missões, fixando-se os limites do território português sobre o Rio Uruguai.

A evolução histórica através das diferentes condições econômicas e políticas que perpassaram também pelas guerras Guaranítica e Cisplatina $^{14}$ foram determinantes para a fragmentação do território das Missões Jesuítico-Guarani e a formação dos estados nacionais brasileiro, argentino, paraguaio e uruguaio (figura 2) transformando o antigo território ${ }^{15}$ dos "Trinta Povos das Missões" uma região transfronteiriça.

${ }^{14}$ (1825-28) o Brasil entra em guerra contra a Argentina pela posse da Banda Oriental. Desse conflito, o Uruguai surge como nação independente.

${ }^{15}$ No campo geográfico, assim como na teoria do direito, o território se define pelo exercício do poder sobre um espaço, logo pelo seu domínio político. ... É assim, um resultado do exercício do poder, o qual pode ser lido em suas paisagens estruturas. MORAES, A. C. R. Capitalismo Geografia e Meio Ambiente. São Paulo: DG/USP, 2000. Tese para concurso de obtenção de título de Livre Docente. 


\section{AS MISSÕES JESUÍTICO-GUARANI E A FORMAÇÃO DO TERRITÓRIO DO RIO GRANDE DO SUL}

A ocupação humana do território atual, de acordo com os estudos arqueológicos, remonta aos 12700 anos antes da colonização européia. Neste período destacavam os grupos humanos dos Ge, dos Pampeanos e dos TupiGuarani. No espaço ocupado pelos Tupi-Guarani foram estabelecidas as Reduções Jesuíticas.

Inexistem documentos escritos sobre o modo de vida dos habitantes desse território no período que antecede a chegada dos colonizadores ibéricos. Já sobre o período posterior ao contato entre o índio e o europeu, é possível conhecer o seu modo de vida e as relações e inter-relações que passaram a ocorrer a partir de um novo modo de vida imposto pelo processo de colonização, através dos registros arqueológicos e das fontes étno-históricas.

Sua área de ocupação,

\footnotetext{
estava integrada nos limites do Império Colonial Espanhol, e nas proximidades de duas capitais provinciais: Assunção e Buenos Aires. A leste, entretanto, os povoados missioneiros guardavam uma fronteira viva, de contínuos choques armados, no qual havia uma permanente oposição de interesses entre a sociedade espanhola e a frente de expansão lusobrasileira. (KERN, 2002, p. 2)
}

A configuração territorial atual foi estabelecida a partir de uma série de negociações diplomáticas entre os países europeus e a Espanha acabou "cedendo" 
a região dos Sete Povos das Missões para Portugal, como visto no final do capítulo anterior. No entanto, até que se chegasse à situação atual, pode-se dizer que a região passou por três períodos históricos bastante significativos que foram: Período pré-jesuítico, Período jesuítico, Período pós-jesuítico.

\subsection{PERÍODO PRÉ-JESUÍTICO:}

No momento da chegada das primeiras frentes de colonização ibérica, os Guarani, originários do sul da Amazônia há cerca de 2000 anos, ocupavam uma faixa localizada entre os paralelos de $23^{\circ}$ e $33^{\circ}$ de latitude sul, na área de abrangência da Bacia do Rio da Prata. Integrados por mais de um milhão de indivíduos que "possuíam um singular arranjo técnico-econômico, perfeitamente adaptado às condições ecológicas" (SOUZA, 1997, p. 99) o que Ihes permitiu instalar um "sistema econômico bastante estável, baseado no cultivo de plantas tropicais combinado com a caça de animais da floresta e a pesca nos rios e lagos". (SCHIMITZ, 1999, p. 144)

Seus territórios de caça pesca e coleta ocupavam amplos espaços nos férteis vales dos rios Paraguai, Paraná, Uruguai e Jacuí, bem com o seus afluentes. O ambiente deveria também ser capaz de suprir outras necessidades dos grupos como a argila para a cerâmica, os afloramentos de rochas para a elaboração dos implementos líticos, as fibras vegetais para a cestaria, as penas de aves para a ornamentação pessoal, as madeiras para as armas, casas e canoas.(KERN, 1994, p. 104) 
Suas aldeias buscavam os vales quentes e úmidos bordejados por floresta tropical e sub-tropical conforme pode ser observado na figura 17.

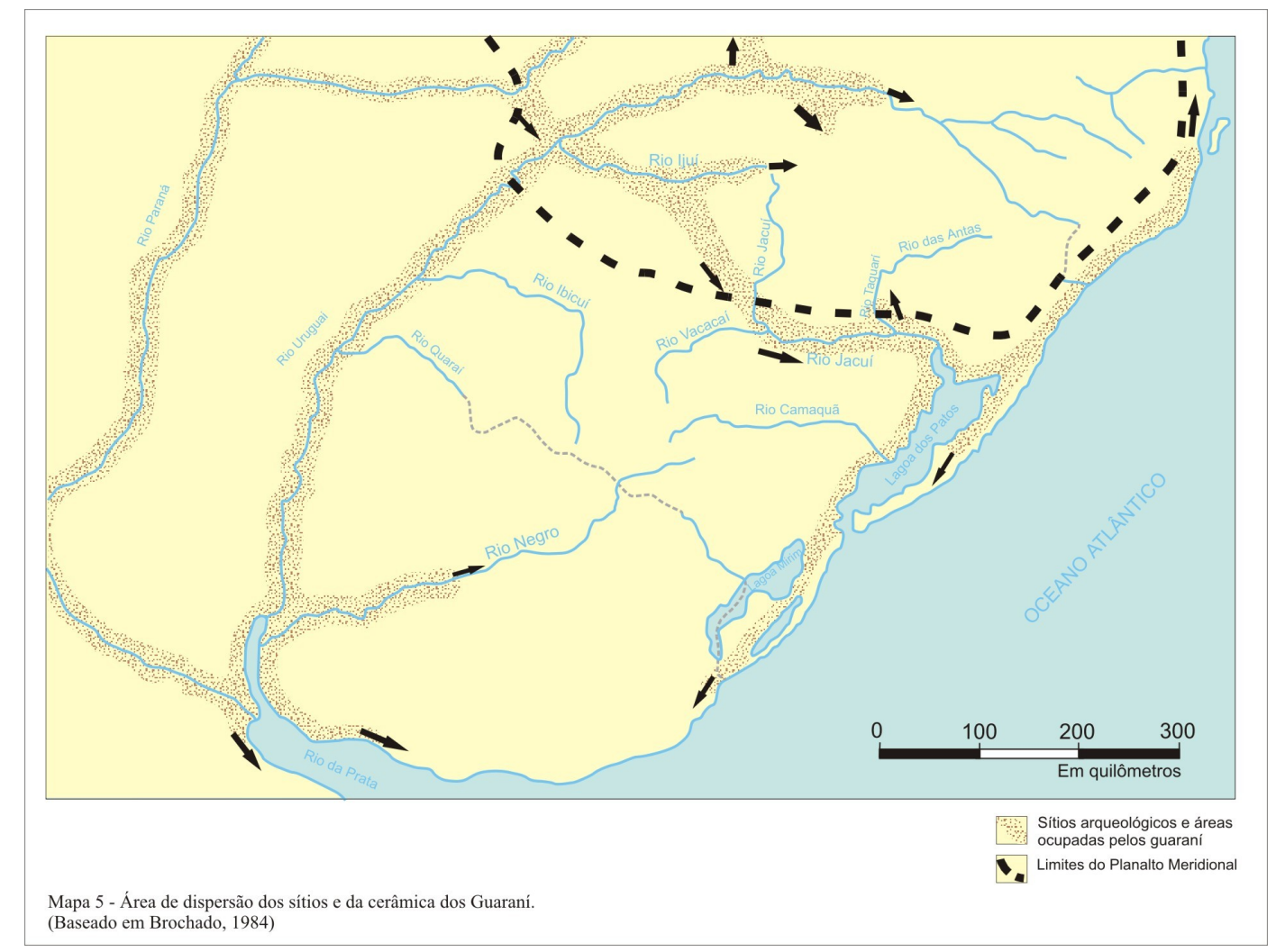

Figura 17: mapa da Localização dos Guarani Pré-Jesuíticos Fonte: Adaptado de Kern (1994, p. 90)

Denominados de "horticultores - cultivadores da floresta tropical" utilizavam o sistema de coivara que consistia na abertura de clareira e queima do mato para a realização do plantio. Esse sistema possibilitava o cultivo consorciado de diversas plantas como o milho, a mandioca, a batata-doce, o cará, o amendoim, o feijão, a abóbora, o inhame, o fumo, o algodão, o porongo, além de plantas frutíferas e 
medicinais. Para sua sobrevivência, combinavam o cultivo com a caça, a pesca e a coleta de produtos e alimentos como o mel e o coco além de cera e plantas medicinais.

Eram seminômades, viviam em aldeias, usavam embarcações fluviais e, como pode ser observado na ilustração de Keller (figura 18), utilizavam rede de dormir, guardavam os objetos em giraus, sentavam em banquinhos ou esteiras. Manufaturavam a cerâmica onde guardavam líquidos e grãos e preparavam seus alimentos em fogo-de-chão. Estabeleciam-se, sempre que possível, no seio da mata, evitando a paisagem aberta dos campos.

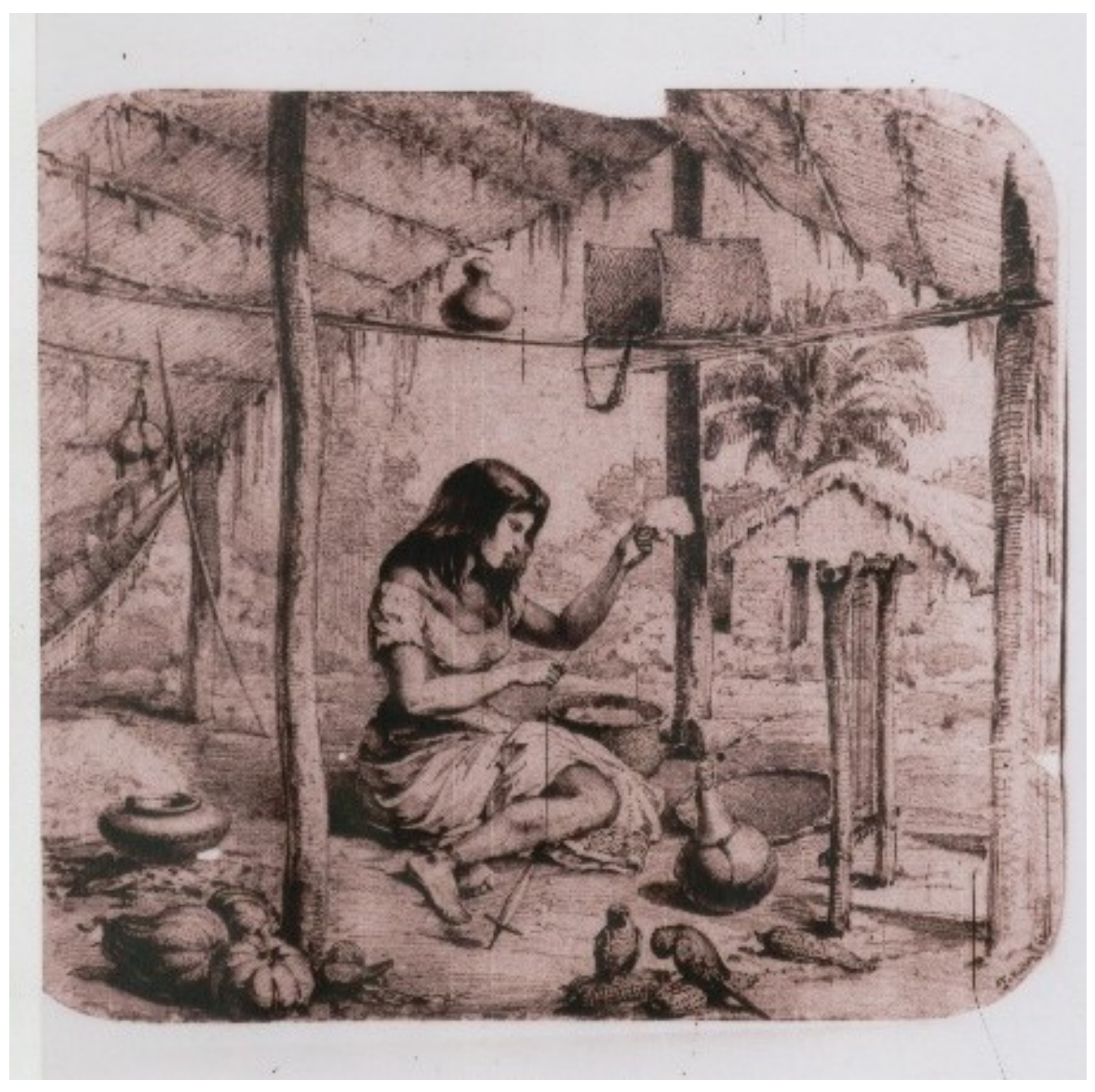

Figura 18: Gravura do o espaço interno da habitação Guarani Fonte: KELLER (arquivo do Centro de Cultura Missioneira - G - 003) 
Conforme pode ser observado nas ilustrações de Debret (figura 19), existiam diferentes tipos de habitações guarani. A maioria das habitações dos Guarani, no entanto, eram constituídas por casas comunais de forma alongada, com grandes imensões que abrigavam uma linhagem ${ }^{16}$ inteira. Não possuíam divisões internas, tendo uma porta para os homens e outra para as mulheres.

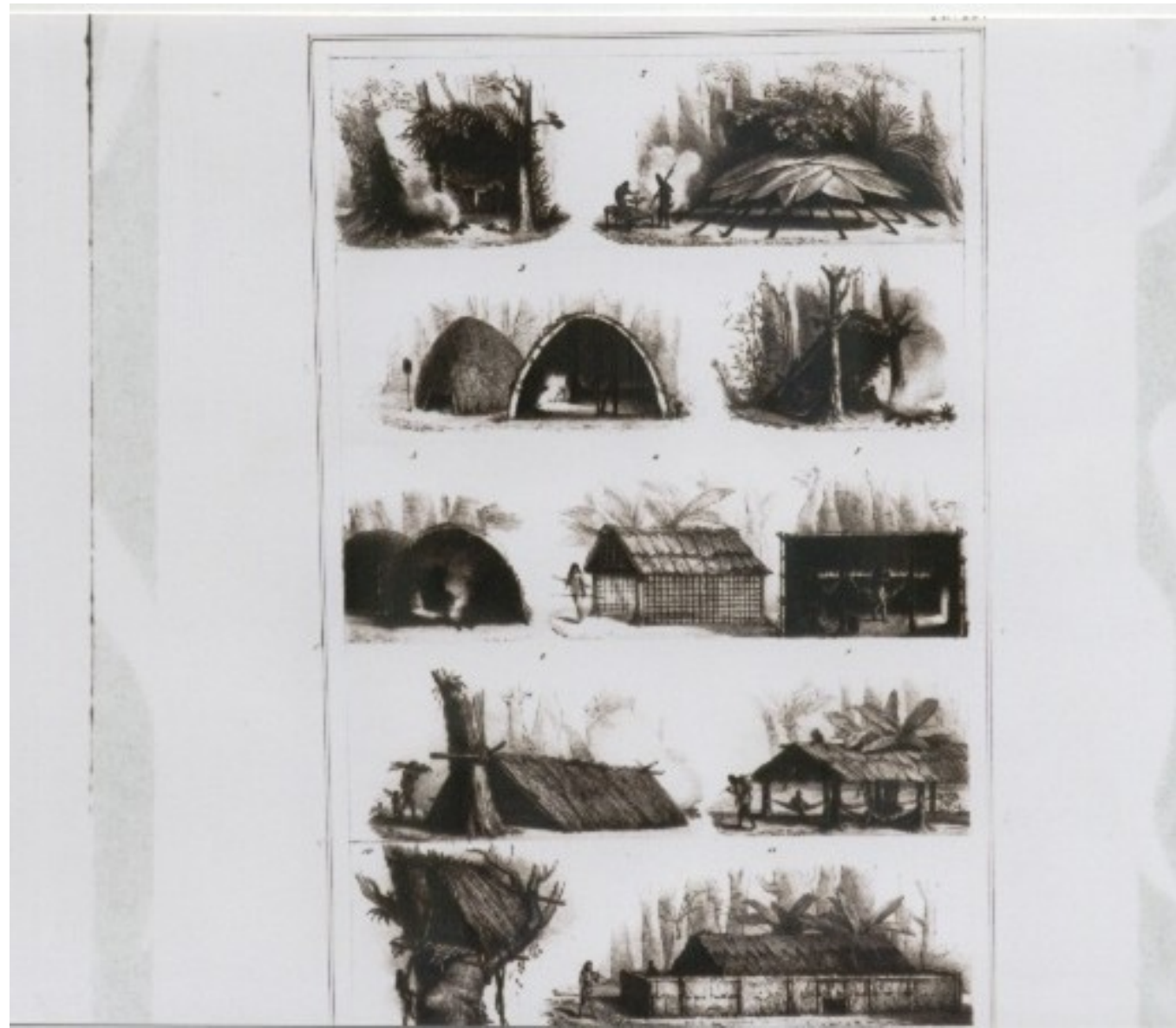

Figura 19: gravura das habitações Guarani

Fonte: arquivo do Centro de Cultura Missioneira - RE - 035

${ }^{16}$ Linhagem ou família extensa: unidade socioeconômica de base dos Guarani - engloba os descendentes de um ancestral comum, com suas mulheres que viviam em uma grande casa (NECKER, 1990, 27) 
Conforme Souza (1987) a distribuição da linhagem nas casas comunais tem correspondência na divisão dos fogos e dos lotes, demonstrando ser expressão de uma unidade sócio-econômica na qual se dividem as terras, os pesqueiros e, inclusive as zonas de caça. A linhagem, sozinha ou unida a outras, pode constituir aldeias compostas de diferentes concentrações populacionais. Na região das Missões Jesuítico-Guarani variava entre 150 a 200 habitantes. Para Schadem (1974, p. 25) "a linhagem constituía a célula comunitária dos Guarani - uma comunidade de produção, consumo e vida religiosa". Suas aldeias possuíam casas dispostas em círculo em torno de um espaço coletivo de circulação, reunião, danças, desportos e rituais sagrados. Eram protegidas por uma paliçada de troncos conforme pode ser observado na figura 20 .

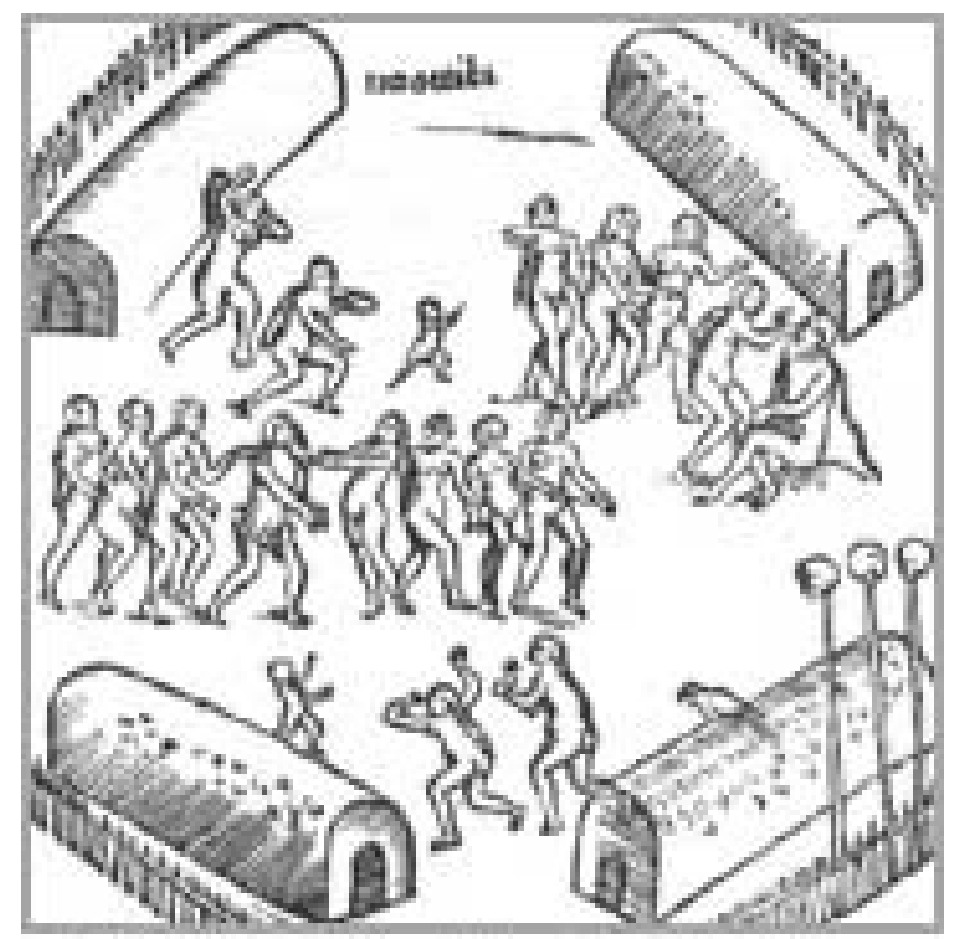

Figura 20: desenho de uma aldeia Guarani 
Inexistia a propriedade privada e o grupo, como um todo, dispunha da posse de um determinado trecho. Em geral de várzea, efetivamente ocupado, de onde cada família e cada indivíduo retirava os meios necessários à sua sobrevivência. De acordo com Lessa (1999, p. 73) "inexistindo o conceito de propriedade privada, inexiste a divisão social entre pobres e ricos. Também, não se conhecem governantes e governados. As decisões são tomadas pelo grupo." Existia, no entanto, a "divisão sexual do trabalho para a produção da horticultura" (SOUZA, 1987, p. 241) sendo que aos homens cabia a derrubada do mato, o amontoamento dos galhos e a sua queima; a produção de armas e instrumentos, canoas, mobílias e plumaria; além da prática da guerra; da proteção permanente da mulher e dos filhos; da construção das habitações; da obtenção do fogo; da confecção de cestos de folhas de palmeira ou taquarinha, o exercício das atividades de pagé (médico, sacerdote, mago) de Avaré (ou diretor de cerimoniais de cultos religiosos); e cumprir com o resguardo quando nascia um filho. Às mulheres correspondiam as tarefas de plantio, limpeza da roça e colheita; a realização das lidas domésticas; a produção de vasilhames de cerâmica; a fiação e tecelagem; a ajuda na construção das habitações; o acompanhamento dos guerreiros para preparar os alimentos, abastecer de água, ajudar no transporte de víveres e redes; a manutenção do fogo aceso. O recolhimento de raízes e frutas; a fabricação de farinhas, azeite de coco e bebidas fermentadas; a fabricação de cestos de junco e folhas de taquarinha; domesticar e cuidar de aves e animais, ajudar no parto de outras mulheres. As 
crianças ajudavam no plantio, limpeza da roça e na colheita, além de ajudar a cuidar dos menores.

Conforme Flores (2003, p. 17) "o espaço geográfico do Guarani - o teko hã ${ }^{17}$ era formado pela aldeia, pelas casas, pelas roças, pelos caminhos e pelo mato" conforme figura 5. Para Martins (1999, p. 112) este era o espaço físico existencial do índio Guarani e consistia em um território onde ele vivia livre, dentro de uma perspectiva material e espiritual própria. O seu eventual nomadismo prendia-se á procura de novas terras para o cultivo e, no plano espiritual, na procura da "terra sem males ${ }^{18 ، .}$

Nota-se, na figura 21, que as roças (C) tinham uma ligação direta com a aldeia (A) através dos caminhos (D). As casas (B) dispunham-se em torno de um espaço coletivo sendo que o conjunto todo localizava-se em uma clareira da mata.

\footnotetext{
${ }^{17}$ povoado onde podiam encontrar-se de 3 a 8 casas - linhagens (NECKER, 1990, p. 27)

${ }^{18}$ Um lugar onde não falta caça, pesca e muita paz.

http://www.rosanevolpatto.trd.br/lendacruzadaguarani1t.htm
} 


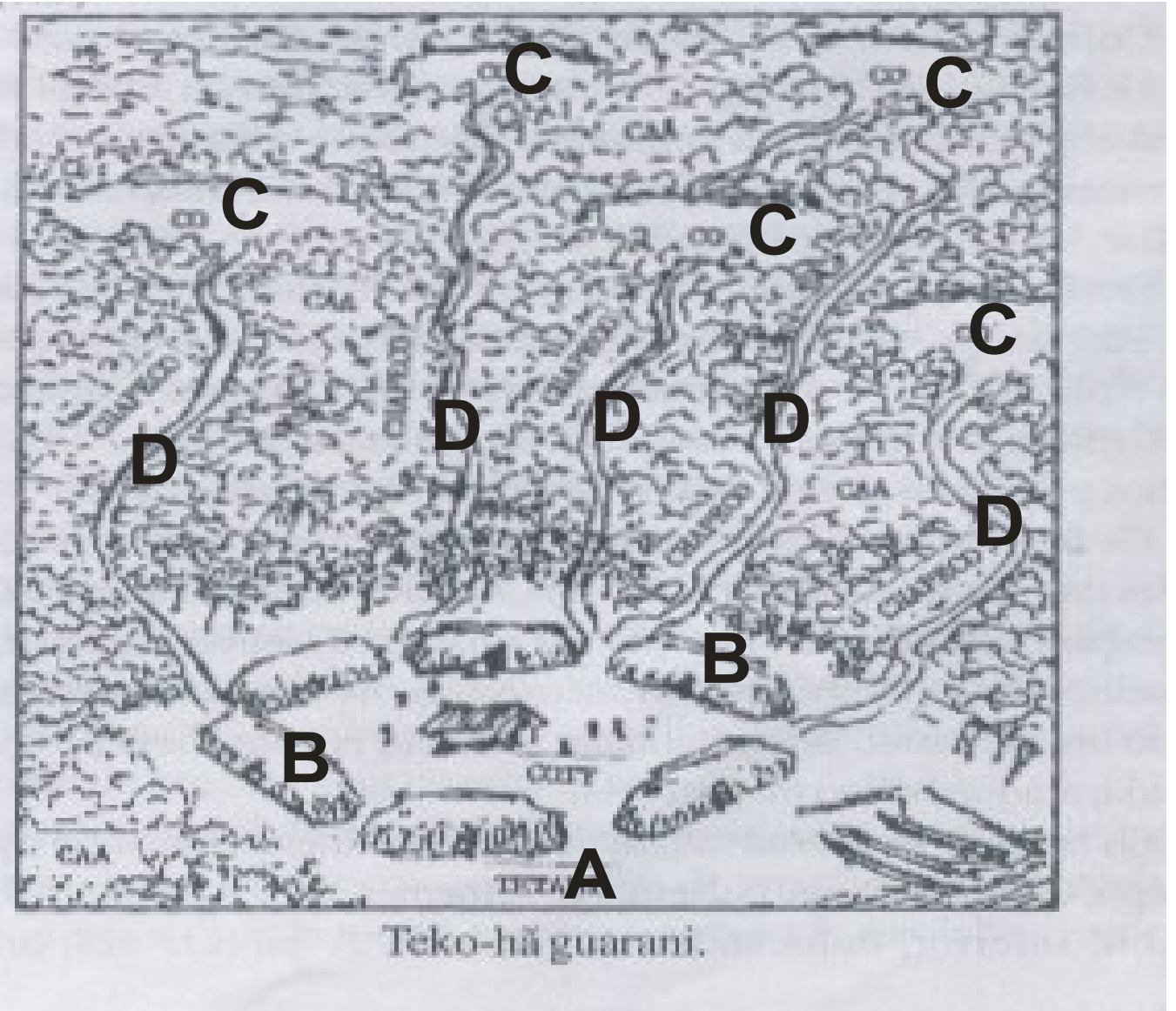

Figura 21: desenho do TEKO-HÃ

Fonte: Flores (2003, p. 17)

$$
\text { A-Aldeia B-Habitações C-Roças D-Caminhos }
$$

Nesse contexto, o modo de vida do Guarani facilitou o trabalho das missões porque por serem

essencialmente agricultores, semi-sedentários, felizes, os guaranis pareciam caindo de maduro para que sobre eles se concentrasse a conquista civil e espiritual que o Vice-Reinado do Peru necessitava empreender. Bastaria que cada taba fosse atraída mansamente, e que as muitas tabas fossem sendo reagrupadas em porções cada vez mais amplas, até que se chegasse à formação de populosos redutos, ou reduções. (LESSA, 1999, p. 67) 
Assim. Inicia-se a instalação das Reduções Jesuítico-Guarani na região, hoje, conhecida como Região das Missões.

\subsection{PERIODO JESUITICO}

Com a implantação das reduções jesuítico-Guarani numa área correspondente a 490 mil quilômetros quadrados envolvendo territórios atuais do Brasil, da Argentina, do Paraguai e do Uruguai, inicia-se a destruição da vida tribal Guarani. De acordo com Quevedo (2000, p. 73 ) "a redução era a negação da organização político Guarani e uma tentativa de conduzir o índio a aceitar a passagem da vida tribal seminômade para uma comunidade cristã sedentária".

Para o autor, através do projeto missionário, os jesuítas transformaram o Guarani até então seminômade, em sedentário, desencadeando trabalhos com regras pré-estabelecidas e abandonando algumas práticas de sua cultura como a da poligamia e o culto de divindades tribais.

A partir da sua redução, altera-se a forma com que o guarani se relaciona com a natureza especialmente em decorrência da nova forma de habitar e produzir. Ao contrário do antigo teko hã demonstrado na figura 5 , as reduções eram "espaços urbanos em meio a mata, construídos sobre coxilhas, num plano mais alto" (DALTO, 1999, pág 16), nos quais as atividades econômicas eram desenvolvidas de "forma mista: através da propriedade privada da terra (o abambaé) e a propriedade coletiva da terra (o tupambaé)", sendo que esta, prevalecia sobre a 
primeira constituindo o fundamento sobre o qual se apoiava a economia nas reduções.

O abambaé (propriedade do homem) era de usufruto direto das famílias. Cada chefe de família recebia um lote de terra do qual pudesse tirar o sustento dos seus. Nele o casal trabalhava quatro dias da semana. Já o tupambaé (propriedade de Deus) era destinado ao sustento da comunidades, das obras, dos índios envolvidos em atividades artesanais ou incapacitados. A ele dedicavam-se os filhos solteiros e, em dois dias da semana, sábado e segunda-feira, seus pais. Correspondia ao tupambaé a agricultura extensiva que era realizada com sistema de rotação de cultura; a criação do gado (bovino, eqüino e ovino) que realizava-se fora do espaço da redução, nas estâncias; a indústria na qual se destacava a têxtil (algodão e lã) a carpintaria, a fundição, a ferraria e a olaria; e o comércio que se realizava a partir da venda do excedente, principalmente da erva-mate, cuja venda servia para o pagamento do tributo real, em forma de moeda e que correspondia a terça parte dos benefícios do patrimônio público.

A economia das reduções caracterizava-se pela auto-suficiência e a complementaridade. Conforme Abou (1996, p. 77) "cada redução constituía uma unidade econômica independente, no entanto realizavam intercâmbios entre si", não havendo circulação de moeda entre elas e sim de produtos, através da troca.

Para Schimitz (1999, p. 155) este regime misto de propriedade da terra era necessário "porque a vida na redução, com sua estrutura urbana, em um número 
grande de indivíduos, exigia uma agenda apertada de trabalho, reserva de mantimentos e disciplina de consumo".

Portanto, para a alimentação de tantos integrantes de uma redução, o "trabalho sério e disciplinado era absolutamente indispensável, já como meio de subsistência, já como método de educação" (BRUXEL, 1987, p. 63). Cada habitante da redução tinha uma tarefa designada e os trabalhos semanais repartiam-se entre o trabalho nas terras próprias e o dedicado à comunidade. O trabalho não passava de seis horas diárias e no domingo o trabalho era proibido porque era o dia que dedicavam-se a Deus. Participavam da missa, de jogos, danças, representações teatrais, almoço comunitário e desfile militar, além de reunirem-se na praça para expor e discutir problemas da comunidade frente aos padres e os membros do cabildo. (ABOU, 1996). Os homens se ocupavam da roça, das oficinas e das estâncias, enquanto que as mulheres dedicavam-se às atividades domésticas e de fiação da lã e do algodão. As crianças cuidavam dos campos semeados e as viúvas e anciãos dedicavam-se à fiação de tecidos e à educação. Conforme Bruxel

Alguns meninos, especialmente os filhos dos caciques, iam à escola de primeiras letras, outros às aulas de canto, música e dança, ou às oficinas, enquanto a maioria trabalhava nas roças comuns. Os rapazes extirpavam o inço dos algodoais com uma paleta de boi, arrastavam a lenha miúda para as olarias e varriam as ruas; as meninas colhiam flocos de algodão, ficando para as mais novas a divertida ocupação de espantar os papagaios e periquitos, que esbulhavam os milharais. (1987, p. 63) 
A alteração do ambiente natural foi dinamizada pela " introdução de novas espécies vegetais e animais e exploração seletiva de espécies nativas. A introdução do gado vacum, da videira, do pêssego, da pêra e dos citrus, aliado a domesticação da erva-mate e outras espécies autóctones deu início a um processo de degradação das florestas". (SILVA, 2004, p. 2)

O centro de cada redução era a grande praça para a qual convergiam as ruas principais, como pode ser observado na figura 6 . No entorno da praça distribuíam-se os demais elementos arquitetônicos da redução como pode ser observado na figura 22.

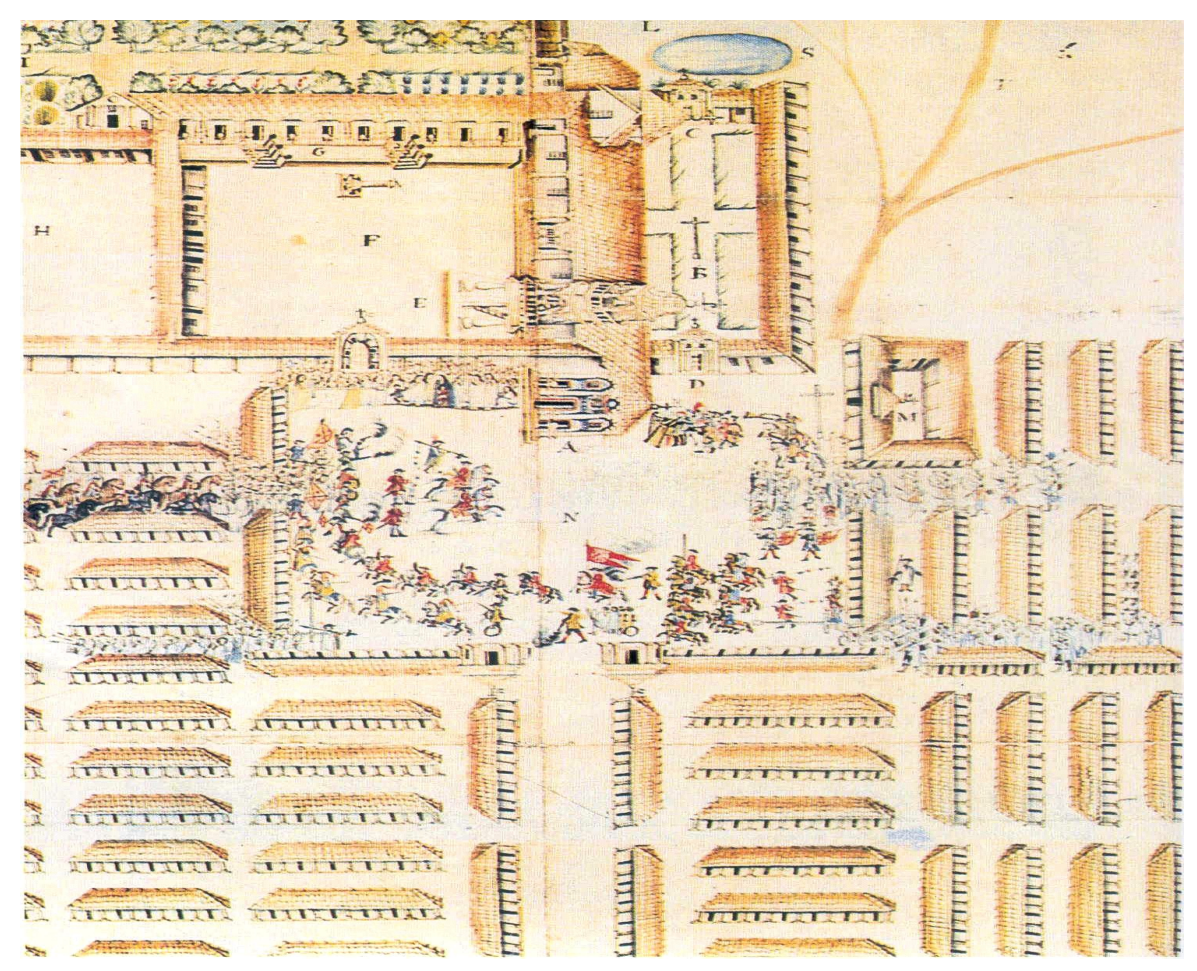

Figura 22: tela da Planta de uma Redução

Fonte: Morales (1997, p. 64)

Em relação às habitações, os Guarani não reduzidos que viviam em aldeias ou casas comunais, dispostas em círculos (figura 4 da, página 41) passaram, na 
redução, a viver em um sistema de blocos de seis a oito salas separadas umas das outras por uma parede destinada cada uma a uma família nuclear, porque para os jesuítas a coabitação de muitas pessoas nas antigas cabanas Guarani constituía-se em uma "promiscuidade que representava inconvenientes de ordem moral e sanitária" (ABOU, 1996, p.69) O conjunto de casas (salas) enfileiradas sob o mesmo teto, era cercado por um alpendre que protegia da chuva e do sol, como pode ser observado na figura 23. Para Tricário o uso do alpendre era marcante como elemento de solidariedade pois:

Dispostos entre a casa efetivamente privada e a rua pública, ele determinava um local que intersecciona, socialmente, fatos da família com o povoado (onde a rua é o suporte da esfera pública na vida cotidiana). Reunidos após o trabalho de rotina, a família se encontrava no alpendre entre conversas e encontros com aqueles que passavam pela rua. (1998, p. 59) 


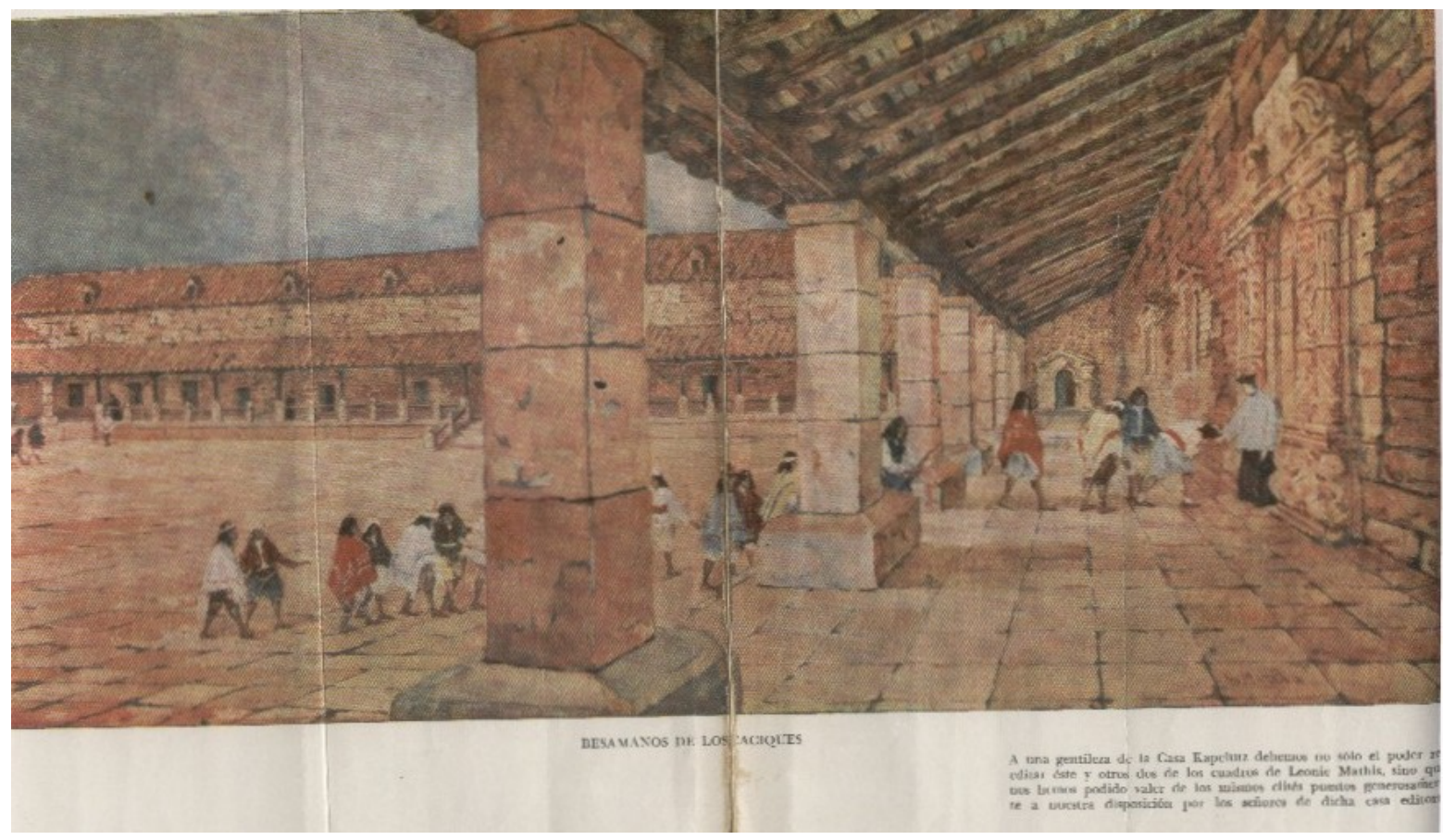

Figura 23- tela sobre o espaço interno da redução

Fonte: Furlong, (1962, p. 241)

$\mathrm{Na}$ área externa da redução exista moinho, forno de pão, graneleiro, depósito de alimentos, matadouro, açougue, forno de ladrilhos, ferraria, ervais, lavouras, além das vacarias estâncias que correspondiam às áreas de criação de gado sob os cuidados dos homens.

Como instituições de fronteira, as missões tinham importante papel na geopolítica espanhola. Estavam sob verdadeira e efetiva dependência do rei da Espanha a quem pagavam tributos e prestavam inúmeros serviços. "Dentre os muitos importantes serviços que os índios missioneiros prestavam à Espanha, lembramos primeiramente a defesa territorial contra o luso" (BRUXEL, 1987, p. 23). Para combater o expansionismo português foram criadas as milícias missioneiras, que eram responsáveis pela defesa das reduções e das fronteiras. Cada redução 
tinha sua milícia, e o conjunto, as 30 reduções contavam com 20 mil integrantes equipados, conforme Kern (2002, p. 3) "com suas tradicionais armas de guerra (lanças, arcos e flechas, tacapes) e com arcabuzes europeus". Para Quevedo (2000, p. 83) as milícias, além de defender a fronteira "deviam avançá-la, interiorizando o domínio espanhol".

Para o seu bom funcionamento, as reduções possuíam um sistema administrativo representado pelo Cabildo ou Conselho de Cabildantes. O mesmo era integrado pelos padres jesuítas e um grupo de caciques. Exercia os poderes executivo, legislativo e judiciário e estava formado pelo corregedor ou prefeito, que o presidia e representava a mais alta autoridade da Redução; um tenente corregedor o vice-prefeito, os alcaides, ou juízes encarregados de sancionar as infrações ou delitos cometidos dentro da redução; os alcaides da irmandade que tinham a mesma função na área rural e os "legisladores" ou delegados de zonas, que cuidavam da limpeza dos locais e das pessoas e controlavam a presença das crianças na escola e no catecismo; um alferes real, porta-estandarte do rei e chefe militar; policiais encarregados da ordem pública; um escrivão ou secretário. Diretamente subordinados ao Cabildo estavam o mordomo (procurador da fazenda) responsável pelos bens da comunidade, assim como seus auxiliares, contadores, procuradores e chefes de depósitos. De acordo com Bruxel (1987, p. 50) "o Cabildo era um governo fantoche, pois, na prática, quem governava era o cura, cuja opinião, sempre consultada, era decisiva". 
Os índios Guarani tinham habilidades para o canto, para a música, a escultura, a pintura, a dança e o teatro, o que foi aproveitado pelos jesuítas a favor da cristianização. Para Quevedo (2000, p. 208) "a arte teve um papel claramente evangelizador sendo utilizada como um instrumento que permitia confirmar no Guarani-missioneiro a fé católica" o que Boff reafirma ao destacar que:

\footnotetext{
para o sucesso da catequese a melhor compreensão dos conceitos abstratos que ela impunha, foram usados várias estratégias de evangelização. Essas em sua maioria estiveram amparadas em imagens, pinturas, procissões, festividades, teatro, contos, enfim, tudo o que pudesse ser exteriorizado, visível e palpável. (2005, p. 67)
}

Os jesuítas reconheciam o valor da civilização, mas davam mais importância a religião. E para provar a importância atribuída a ela, Bruxel (1987) destaca: o muito ensino religioso dado a todos os índios; o tempo longo dado às práticas religiosas diariamente; a profunda devoção dos índios na recepção dos sacramentos; a dedicação dos índios no arranjo interior e exterior da igreja os muitos cantos religiosos em língua guarani; a vida inocente da grande maioria dos índios.

Ainda conforme o mesmo autor, em relação à educação, a Companhia de Jesus tinha por norma universal a fundação de uma escola, logo ao estabelecer-se em algum lugar. Esta escola não atendia apenas as necessidades de ler e escrever, mas principalmente de educação da juventude na vida cristã através dos quais pretendiam atingir também os adultos bem como formar novos líderes indígenas para atuar na administração das reduções. Freqüentavam a escola os filhos de 
caciques, que seriam os futuros governantes e os rapazes intelectualmente mais bem dotados. Além de escrever, ler e contar aprendiam um ofício bem como adquiriam conhecimentos de técnicas agrícolas como os demais jovens. As meninas aprendiam costura, tricô e bordado.

Nesse contexto, os Guarani, acostumados com uma vida semi-nômade, passaram a viver de forma sedentária e planejada segundo os ideais dos jesuítas que transformaram as reduções em

unidades economicamente desenvolvidas, praticamente autônomas, exportando para a Europa, enviando tributos ao Geral de Cia. em Roma, com influência política dentro dos Estados Católicos da Europa. (Pesavento, apud Colvero, 2004, p. 23).

Nelas sentiam-se protegidos contra o ataque dos bandeirantes e encomenderos. No entanto, a disputa permanente pela posse das terras, entre os colonizadores portugueses e espanhóis, levou a decadência das reduções jesuítico-Guarani.

A configuração territorial regional atual é resultado dos vários acordos diplomáticos (tratados) firmados entre as coroas ibéricas, na tentativa de organizar e direcionar a expansão territorial de ambas as coroas na porção centro-sul da América do Sul.

A expansão portuguesa rumo ao Rio da Prata passou a ser mais efetiva a partir da criação da Diocese do Rio de Janeiro (1676),cujo alcance ia do Espírito Santo até o Rio da Prata pela costa marítima e pelo interior. Esse fato legitimou a tentativa de fundação de uma povoação portuguesa na região platina. Assim, em 1680, à 
margem esquerda do Rio da Prata, foi fundada a fortaleza do Santíssimo Sacramento.(PASSAMAI, 2005). Para viabilizar a chegada de apoio português à povoação de Sacramento e organizar o movimento português rumo aos campos do sul, em 1684 foi iniciado o povoamento de Santo Antonio dos Anjos de Laguna, em território de Santa Catarina. A partir de Laguna inicia-se a exploração do território rio-grandense, através de sucessiva expedições que acabam descobrindo os ervais das reduções missioneiras e a Vacaria del Mar, entre 1715 e 1724 .

Com a "corrida do ouro" iniciada a partir da descoberta de minas de ouro em Minas Gerais (1694) e, posteriormente em Goiás e Mato Grosso, os rebanhos do sul ganharam importância ligando a região sul como economia subsidiária à economia central de exportação. O comércio de mulas para as zonas mineradoras tornou-se um negócio muito rendoso e através dele abriram-se novos caminhos para o deslocamento dos animais e em 1938 foi descoberta a Vacaria dos Pinhais. A abertura destes caminhos provocou a marginalização e decadência da Vila de Laguna ao mesmo tempo em que atraiu moradores de Laguna, São Paulo e de Colônia de Sacramento, para os Campos de Viamão (figura 24.) Mostardas e Tramandaí.

A implantação de núcleos militares estáveis foi uma estratégia utilizada para dar continuidade ao expansionismo português. Nesse sentido foram implantados os fortes de Santana, de São Miguel e o presídio Jesus-Maria-José (1737) que deu origem à cidade de Rio Grande, ponto estratégico para a ocupação do sul. 
Pela premência em povoar e garantir a posse das terras pertencentes aos Sete Povos das Missões, que haviam sido trocados pela Colônia de Sacramento através do Tratado de Madrid, em 1752 chegam ao sul casais de açorianos através dos quais o governo objetivava assegurar a posse das terras e colonizar a região a partir da introdução de uma economia de subsistência para abastecer as tropas sediadas no Rio Grande do Sul. No entanto estes casais não receberam a ajuda que Ihes havia sido prometida (auxílio financeiro, espingarda, enxada, facão, dois alqueires de sementes, duas vacas e uma égua, além de farinha) para seu sustento durante o primeiro ano. Por isso acabaram radicando-se em Mostardas, Estreito, São José do Norte, Taquari, Santo Amaro, Porto Alegre, Santo Antonio da Patrulha, Cachoeira e Conceição do Arroio, no Rio Grande do Sul. 


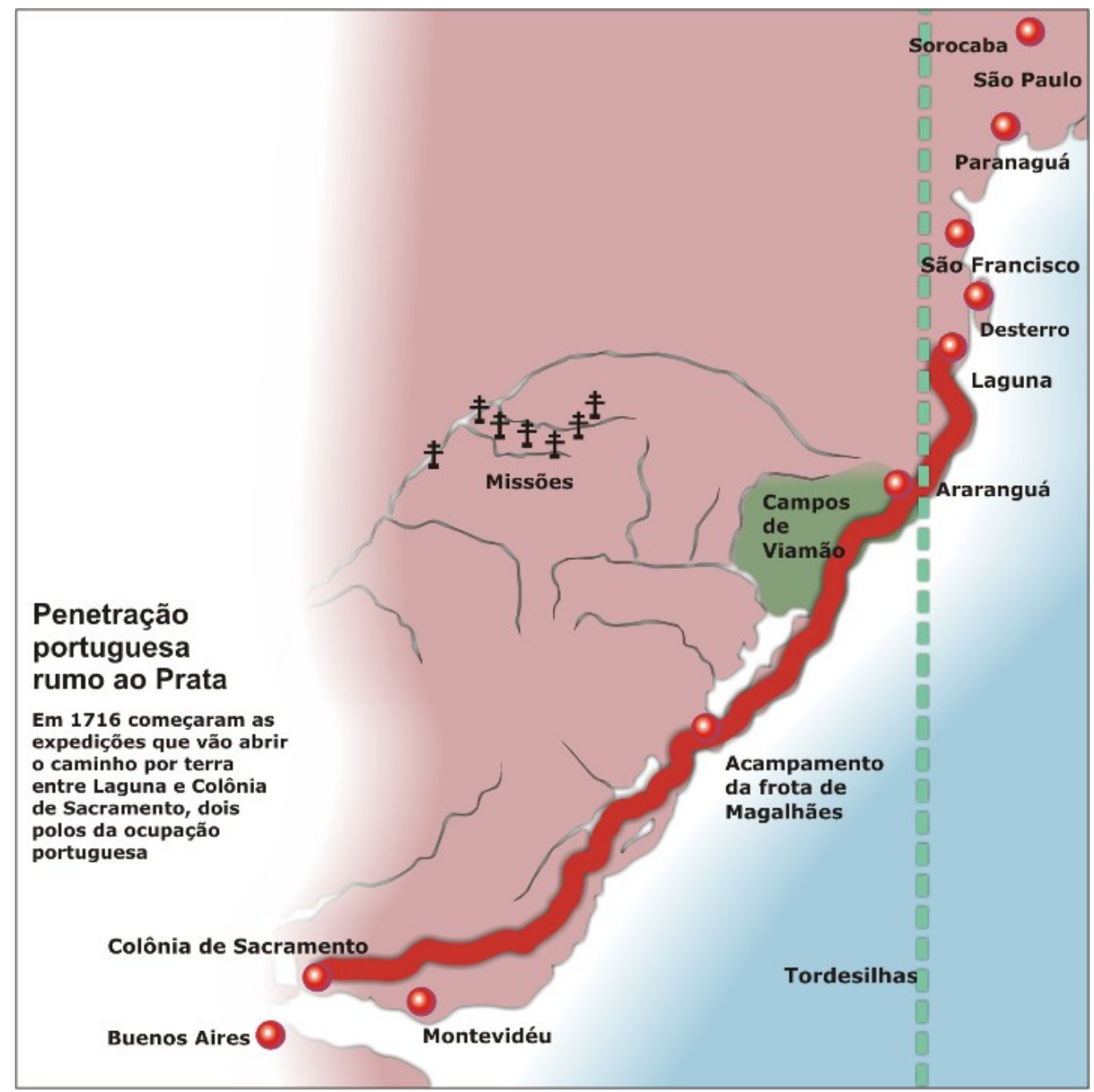

Figura 24 mapa da expansão portuguesa rumo ao Prata

Fonte: adaptado de Costa, Fonseca e Schitti (2004, p. 54)

O lusitanos utilizaram como garantia para efetivar a posse das terras, a distribuição de sesmarias ${ }^{19}$ e a militarização. A partir da metade do século XVIII "a coroa portuguesa distribuiu terras aos tropeiros e militares que deram baixa e

\footnotetext{
${ }^{19}$ Terras devolutas, medindo em regra três léguas por uma légua (cerca de 13000 hectares).
} (PESAVENTO, 1982, p.15) 
afazendaram-se, definindo-se a posse da terra e do gado com o estabelecimento das estâncias" (PESAVENTO, 1982, p. 15)

Em relação ao processo de ocupação e apropriação do território missioneiro (brasileiro) destaca-se sua ocupação por militares ou negociadores de gado que a partir da apropriação do gado deixado nas estâncias jesuítico-Guarani, instalam grandes estâncias agropastoris. Conforme Zarth (1994) já em 1860 não haviam campos nativos para serem incorporados, iniciando-se a apropriação das áreas florestais onde viviam os ervateiros, a quem restaram as terras inóspitas ou devolutas ou a submissão ao trabalho nas estâncias pastoris ao lado dos escravos negros, o que deu origem a sérios problemas que persistem ainda hoje.

Por ser considerada uma região estratégica, fronteira com países da bacia do Prata, a Região das Missões era objeto de grande preocupação do governo, cuja política oficial era de criar núcleos de povoamento ao longo da fronteira. Devido ao isolamento da área esses núcleos não se efetivaram.

Para a Região das Missões houve uma tentativa de implantação de uma colônia alemã em 1825. Foi em 1890, porém, que implantou-se uma colônia em ljuí. O processo de colonização através de colônias de imigrantes europeus foi vista como uma saída para a economia estagnada da região já que "o comércio de mulas perdia sua importância, o gado vacum era criado sem melhorias técnicas e a ervamate sofria concorrência da produção do estado do Paraná". (ZARTH, 1994, p. 461) A nova forma de apropriação da terra, baseada na grande propriedade pastoril, no extrativismo da erva-mate e, posteriormente, na implantação da pequena 
propriedade agrícola originária do processo de distribuição e comercialização de terras aos imigrantes europeus, "promoveu a construção de um novo tipo de sociedade, diferente daquela construída pelos indígenas sob o controle dos jesuítas" ( op cit?)

Nesse contexto, forjaram-se as fronteiras do Rio Grande do Sul que possui uma superfície de $282.184 \mathrm{~km}^{2,}$ localizados ente os paralelos de $27^{\circ} 03^{\prime} 42^{\prime \prime}$ de latitude norte e $33^{\circ} 45^{\prime} 10^{\prime \prime}$ de latitude sul e os meridianos de $49^{\circ} 42^{\prime} 31^{\prime \prime}$ de longitude leste e $57^{\circ} 40^{\prime} 57^{\prime \prime}$ de longitude oeste (mapa 2). Sua configuração territorial atual, de acordo com Silveira e Adamezuk (2004) equivale à figura de um losango, no qual cada um de seus quatro lados constitui-se numa fronteira distinta. O estado tem ao sul a República Oriental do Uruguai, com 1003 km de linha de fronteira sendo que dois terços dela foram demarcados considerando-se acidentes geográficos e o outro terço foi estabelecido por linhas geodésicas. A leste o estado tem $622 \mathrm{~km}$ de litoral no Oceano Atlântico e a oeste, o Rio Uruguai estabelece $724 \mathrm{~km}$ de divisa natural com a República da Argentina. Dos quatro lados do losango, apenas um lado conta com fronteira brasileira. São os $958 \mathrm{~km}$ de limites com Santa Cataria, situada a nordeste do estado Sulista.

\subsection{PERIODO POS-JESUITICO}

Após a derrocada das Missões Jesuítica Guarani a região foi repovoada por fazendeiros portugueses e espanhóis e a partir de 1828 chegaram à região, especialmente em territórios argentino e brasileiro, imigrantes europeus que se 
dedicavam à agricultura. Com eles, introduziu-se uma nova realidade de produção econômica e cultural, mudando, portanto, a fisionomia da região em conseqüência de uma nova forma de combinação e distribuição dos recursos provida pelo movimento histórico.

No entanto, os Trinta Povos Jesuítico-Guarani durante os séculos XVII e XVIII, conformaram não só um âmbito territorial definido como também um sistema integrado na ordem econômica e política-administrativa. A extinção daquela realidade histórica não foi absoluta. Como todo o feito histórico, deixou significativos testemunhos que constituem o patrimônio cultural regional - o conjunto monumental das Missões Jesuítico-Guarani. Suas materialidades apontam hoje para um novo uso comum do território, em busca de melhores condições de vida para a comunidade regional: o desenvolvimento de atividades turísticas.

Além de um passado comum, testemunhado pelos remanescentes históricoculturais materializados em sua paisagem, a coletividade, que atualmente ocupa o espaço outrora constituinte do território das Reduções Jesuítico-Guarani, apresenta outras características que the conferem particularidades. Entre elas destacam-se: um ambiente físico caracterizado pelo clima sub-tropical, relevo sem grandes elevações, cobertura vegetal originalmente constituída por floresta latifoliada e campos utilizados para criação de gado, além da abundância de recursos hídricos; a economia baseada na produção primária, com destaque para o cultivo de soja, trigo, milho, algodão, erva-mate, chá, arroz, entre outros; a indústria voltada ao aproveitamento da produção primária, destacando-se as indústrias alimentícias, 
madeireiras, de máquinas e implementos agrícolas; sérios problemas sociais (aumento da riqueza de uns e pobreza da maioria, êxodo rural, favelamento, analfabetismo) e ambientais (como o desmatamento, degradação do solo, contaminações e assoreamento dos recursos hídricos), decorrentes da forma de ocupação do solo e do processo de modernização do campo; condição de dependência e miséria agudizados pelo desmonte progressivo e sistemático de sua indústria. (NOGUEIRA, 1999)

Através de iniciativas do turismo - baseadas no rico patrimônio histórico - a comunidade regional crê que será possível buscar a integração econômica, via integração cultural, implantando políticas integradas que venham ao encontro do atendimento das necessidades da população, ou seja, o desenvolvimento regional.

Nos quadros que seguem, estão destacadas as principais características do conjunto patrimonial regional. 


\begin{tabular}{|c|c|c|c|}
\hline REDUÇÃO & SITUAÇÃO DOS VESTIGIOS & CARACTERIZAÇÃO GERAL & STATUS LEGAL \\
\hline San Ignácio Miní & $\begin{array}{l}\text { Um dos conjunto mais completo das } \\
\text { missões. Destacam-se os remanescentes } \\
\text { dos dois pátios do colégio e da residência } \\
\text { dos padres. Demonstra a qualidade dos } \\
\text { pavimentos, balaústres, colunas e } \\
\text { portadas. Igreja com parede, ladrilhos e } \\
\text { portas. Casas dos índios com paredes e } \\
\text { divisões internas, casa dos padres com } \\
\text { ladrilhos- }\end{array}$ & 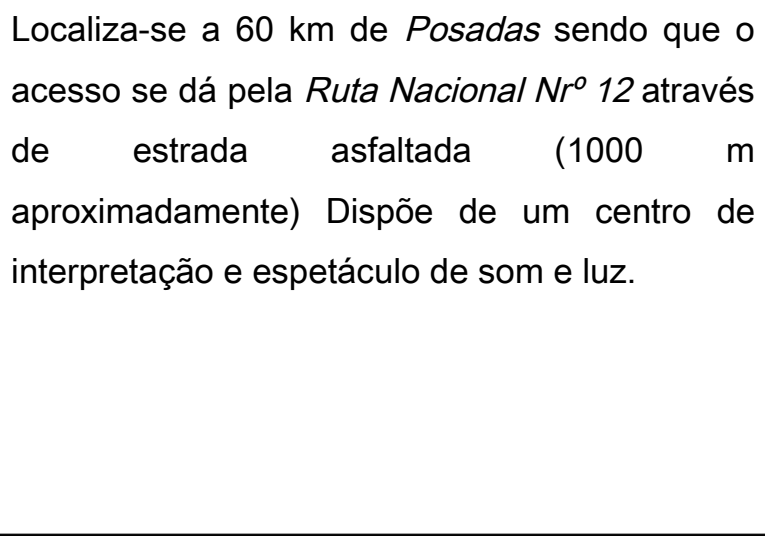 & $\begin{array}{l}\text { Monumento Histórico } \\
\text { Nacional (1943) } \\
\text { Monumento Histórico } \\
\text { Provincial (1983) } \\
\text { Patrimônio } \\
\text { Humanidade (1984) }\end{array}$ \\
\hline San Carlos & $\begin{array}{l}\text { Restam partes de muros tanto dos } \\
\text { contornos dos cemitérios como de } \\
\text { vestígios das vivendas. }\end{array}$ & & \\
\hline Santa Ana & $\begin{array}{l}\text { Paredes laterais e escadaria da igreja, } \\
\text { dutos condutores de água e partes dos } \\
\text { muros do colégio e das oficinas. Destaca- } \\
\text { se o conjunto: oficina-residência-templo- } \\
\text { cemitério. O muro da quinta é o que está } \\
\text { em melhor conservação nos sítios } \\
\text { argentinos. }\end{array}$ & $\begin{array}{l}\text { Localiza-se a } 45 \mathrm{~km} \text { de Posadas sendo que o } \\
\text { acesso se dá pela Ruta Nacional } \mathrm{Nr}^{\circ} 12 \text { através } \\
\text { de caminho vicinal consolidado ( } 2000 \mathrm{~m} \\
\text { aproximadamente). Dispõe de um centro para } \\
\text { visitantes. }\end{array}$ & $\begin{array}{l}\text { Monumento Histórico } \\
\text { Nacional (1983) } \\
\text { Monumento Históricol } \\
\text { Provincial (1969) } \\
\text { Patrimônio } \\
\text { Humanidade (1984) }\end{array}$ \\
\hline Santa Maria Layor & $\begin{array}{l}\text { Restam parte dos muros do colégio, das } \\
\text { residências, das oficinas, do cemitério e } \\
\text { das hortas e da igreja além de colunas da } \\
\text { mesma. }\end{array}$ & $\begin{array}{l}\text { Localiza-se a } 120 \mathrm{~km} \text { de Posadas sendo que o } \\
\text { acesso se dá pela Ruta Nacional } \mathrm{Nr}^{\circ} \\
\text { 105/201/1/2 com estrada pavimentada. Dispõe } \\
\text { de um centro para visitantes. }\end{array}$ & $\begin{array}{l}\text { Monumento Histórico } \\
\text { Nacional (1945) } \\
\text { Monumento Histórico } \\
\text { Provincial (1980) } \\
\text { Patrimônio da }\end{array}$ \\
\hline
\end{tabular}




\begin{tabular}{|c|c|c|c|}
\hline & & & Humanidade (1984) \\
\hline $\begin{array}{l}\text { Nuestra Señora de } \\
\text { Loreto }\end{array}$ & $\begin{array}{l}\text { É um dos melhores conjuntos em toda a } \\
\text { área guaranítica já que conserva de forma } \\
\text { integral e homogênea praticamente todo o } \\
\text { núcleo central do antigo povoado. } \\
\text { Permanecem paredes da igreja, do } \\
\text { colégio e das habitações indígenas. }\end{array}$ & $\begin{array}{l}\text { Localiza-se a } 55 \mathrm{~km} \text { de Posadas sendo que o } \\
\text { acesso se dá pela Ruta Nacional } \mathrm{Nr}^{\circ} 12 \text { através } \\
\text { de caminho vicinal consolidado ( } 2500 \mathrm{~m} \\
\text { aproximadamente) Dispõe de um centro para } \\
\text { visitantes. }\end{array}$ & $\begin{array}{l}\text { Monumento Histórico } \\
\text { Nacional (1983) } \\
\text { Monumento Histórico } \\
\text { Provincial (1969) } \\
\text { Patrimônio da } \\
\text { Humanidade (1984) } \\
\end{array}$ \\
\hline San Javier & $\begin{array}{l}\text { Conservam-se unicamente alguns } \\
\text { embasamentos pertencentes às } \\
\text { residências, às oficinas e ao templo. }\end{array}$ & $\begin{array}{l}\text { Localiza-se a } 122 \mathrm{~km} \text { de Posadas sendo que o } \\
\text { acesso se dá pela Ruta Nacional } N r^{\circ} 12 / 4\end{array}$ & $\begin{array}{l}\text { Lugar Histórico Naciona } \\
(1943) \\
\text { Monumento Histórico } \\
\text { Provincial (1969) }\end{array}$ \\
\hline $\begin{array}{l}\text { Santos Mártires Del } \\
\text { Japon }\end{array}$ & $\begin{array}{l}\text { Restam alguns muros da sacristia e o } \\
\text { presbitério }\end{array}$ & $\begin{array}{l}\text { Localiza-se a } 130 \mathrm{~km} \text { de Posadas sendo que o } \\
\text { acesso se dá pela Ruta Nacional } N r^{\circ} \\
\text { 105/201/1/2 y caminho vicinal em regular } \\
\text { estado. }\end{array}$ & $\begin{array}{l}\text { Monumento Histórico } \\
\text { Nacional (1983) } \\
\text { Monumento Histórico } \\
\text { Provincial (1969) } \\
\end{array}$ \\
\hline $\begin{array}{l}\text { Nuestra Señhora delos } \\
\text { Reyes Magos de } \\
\text { Yapeyú }\end{array}$ & $\begin{array}{l}\text { Possui vestígios dos muros e pavimentos } \\
\text { da Igreja, além de imagens da virgem } \\
\text { missioneiras. }\end{array}$ & Pequeno Museu local & \\
\hline $\begin{array}{l}\text { Imaculada Concepción } \\
\text { de Ibitiracua }\end{array}$ & $\begin{array}{l}\text { As pedras dos muros da antiga redução, } \\
\text { encontram-se incorporadas as novas } \\
\text { construções do novo povoado. Existem } \\
\text { apenas fragmentos de colunas e } \\
\text { esculturas além de capitéis. }\end{array}$ & $\begin{array}{l}\text { Localiza-se a } 86 \mathrm{~km} \text { de Posadas sendo que o } \\
\text { acesso se dá pela Ruta Nacional } N r^{\circ} \\
105 / 201 / 1 / 2 \text { Sobre o traçado Jesuítico se } \\
\text { instalou o traçado da cidade de Concepción de } \\
\text { la Sierra }\end{array}$ & $\begin{array}{l}\text { Lugar Histórico (1969) } \\
\text { Monumento Histórico } \\
\text { Provincial (1969) }\end{array}$ \\
\hline Corpus Christi & $\begin{array}{l}\text { Permanecem partes da lgreja do pátio do } \\
\text { colégio e das habitações indígenas, o }\end{array}$ & $\begin{array}{l}\text { Localiza-se a } 82 \mathrm{~km} \text { de Posadas sendo que o } \\
\text { acesso se dá pela Ruta Nacional } N r^{\circ} 12 \text { a partir }\end{array}$ & $\begin{array}{ll}\text { Monumento } & \text { Histórico } \\
\text { Nacional (1983) }\end{array}$ \\
\hline
\end{tabular}




\begin{tabular}{|c|c|c|c|}
\hline & $\begin{array}{l}\text { cemitério do povoado atual ocupa parte da } \\
\text { antiga praça da redução. }\end{array}$ & $\begin{array}{l}\text { da qual se toma a Ruta Provincial } \mathrm{Nr}^{\circ} 6 \text { até } \mathrm{o} \\
\text { povoado. }\end{array}$ & $\begin{array}{l}\text { Patrimônio Cultural } \\
\text { Provincial (1980) }\end{array}$ \\
\hline $\begin{array}{l}\text { Nuestra Señhora de la } \\
\text { Candelaria }\end{array}$ & $\begin{array}{l}\text { Os vestígios mais evidentes estão nos } \\
\text { terrenos das atuais unidades penitenciária } \\
\text { permanecem também muros colunas e } \\
\text { pisos. }\end{array}$ & $\begin{array}{l}\text { Localiza-se a } 20 \mathrm{~km} \text { de Posadas sendo que o } \\
\text { acesso se dá pela Ruta Nacional } \mathrm{Nr}^{\circ} 12 \text { através } \\
\text { de caminho vicinal consolidado (1200 m } \\
\text { aproximadamente) O povoado atual } \\
\text { estabeleceu-se sobre o traçado urbano da } \\
\text { antiga redução. }\end{array}$ & $\begin{array}{ll}\text { Monumento Histórico } \\
\text { Nacional (1983) } \\
\text { Patrimônio Cultural } \\
\text { Provincial (1980) } \\
\text { Patrimônio da } \\
\text { Humanidade (1984) } \\
\end{array}$ \\
\hline Santa Cruz & Não existem vestígios & & \\
\hline San José & $\begin{array}{l}\text { Permanecem alguns muros e poucas } \\
\text { evidências da antiga redução que são } \\
\text { reconhecidos pelos elevados montículos } \\
\text { de adobe. }\end{array}$ & $\begin{array}{l}\text { Localiza-se a } 41 \mathrm{~km} \text { de Posadas sendo que o } \\
\text { acesso se dá pela Ruta Nacional } N r^{\circ} 1052, \text { logo } \\
\text { depois através de caminho vicinal consolidado } \\
\text { (3000 m aproximadamente) }\end{array}$ & $\begin{array}{l}\text { Lugar Histórico (1943) } \\
\text { Monumento Histórico } \\
\text { Provincial (1969) }\end{array}$ \\
\hline $\begin{array}{l}\text { Santos Apóstoles San } \\
\text { Pedro y San Pablo }\end{array}$ & $\begin{array}{l}\text { Não existem vestígios porque a planta } \\
\text { atual de apostoles se sobre põe a antiga } \\
\text { redução, encontram-se apenas montículo } \\
\text { de adobe correspondentes a partes de } \\
\text { oficinas e do tempo. }\end{array}$ & $\begin{array}{l}\text { Localiza-se a } 57 \mathrm{~km} \text { de Posadas sendo que o } \\
\text { acesso se dá pelas Rutas } \mathrm{Nr}^{\circ} 105 \text { y } 102 \text {, }\end{array}$ & $\begin{array}{l}\text { Lugar Histórico (1943) } \\
\text { Monumento Histórico } \\
\text { Provincial (1969) }\end{array}$ \\
\hline Santo Tomé & Não existem vestígios & & - \\
\hline
\end{tabular}

Figura 25: quadro sobre o patrimônio arquitetônico das missões -Argentina

Fonte:: 


\begin{tabular}{|c|c|c|c|}
\hline REDUÇÃO & SITUAÇÃO DOS VESTIGIOS & CARACTERIZAÇÃO GERAL & STATUS LEGAL \\
\hline Santo Ângelo & $\begin{array}{l}\text { Alicerce e parede de casas de pedra permaneceram } \\
\text { algumas pedras telhados e uma imagem de cristo } \\
\text { morto talhada em madeira policronada. }\end{array}$ & $\begin{array}{l}\text { Distante quatrocentos e cinqüenta quilômetros } \\
\text { de Porto Alegre. Acesso pela BR } 285 \text { e RS } \\
344 .\end{array}$ & Sítio Arqueológico \\
\hline San Francisco de Borja & $\begin{array}{l}\text { Ficou apenas uma imagem de São Francisco de } \\
\text { Borja, localizada na igreja matriz atual }\end{array}$ & $\begin{array}{l}\text { Localizada cento e noventa quilômetros de } \\
\text { Santo Ângelo, sendo que o acesso é dado } \\
\text { pelas BR } 472 \text {, BR } 285 \text { e BR } 287 \text {. }\end{array}$ & Sítio Arqueológico \\
\hline San Nicolás & $\begin{array}{l}\text { Permanecem paredes e estruturas da } \\
\text { Igreja e edifícios anexos, entre eles o } \\
\text { cabildo e ruas, piso original da Igreja seu } \\
\text { entorno, casa de índio, e adega } \\
\text { subterrânea. }\end{array}$ & $\begin{array}{l}\text { Localizado a cento e vinte quilômetros de Santo } \\
\text { Ângelo, o acesso é dado pela estrada BR } 285 \text { e } \\
\text { RS } 168 .\end{array}$ & $\begin{array}{l}\text { Sítio Arqueológico } \\
\text { Patrimônio Nacional } \\
\text { (1970) }\end{array}$ \\
\hline San Lorenzo & $\begin{array}{l}\text { Permanecem partes da fachadas da Igreja e muro } \\
\text { interior, elementos construtivos das casa dos jesuítas } \\
\text { e um cemitério com tumbas antigas e modernas.; e } \\
\text { dos pavimentos próximos ao antigo templo. }\end{array}$ & $\begin{array}{l}\text { Localizadas a cinqüenta quilômetros de Santo } \\
\text { Ângelo com acesso pela BR } 285 \text {, com uma } \\
\text { entrada de seis quilômetros não pavimentada. }\end{array}$ & $\begin{array}{l}\text { Sítio Arqueológico } \\
\text { Patrimônio Nacional } \\
\text { (1970) }\end{array}$ \\
\hline San Juan Baltista & $\begin{array}{l}\text { Paredes laterais da igreja, partes dos muros da } \\
\text { escola, das oficinas, da casa dos padres, forja da } \\
\text { antiga fundição de ferro }\end{array}$ & $\begin{array}{l}\text { Localizado a vinte e três quilômetros de Santo } \\
\text { Ângelo, seu acesso se dá pela BR } 285 \text { tendo } \\
\text { em sua entrada sete quilômetros pela estrada } \\
\text { não pavimentada. }\end{array}$ & $\begin{array}{l}\text { Sítio Arqueológico } \\
\text { Patrimônio Nacional } \\
\text { (1970) }\end{array}$ \\
\hline $\begin{array}{l}\text { São Miguel } \\
\text { Arcanjo r }\end{array}$ & $\begin{array}{l}\text { Igreja com paredes e com fachada quase completa. } \\
\text { Partes dos muros do colégio, das oficinas, do } \\
\text { cotiguaçu, do cemitério e da quinta. Fonte de }\end{array}$ & $\begin{array}{l}\text { Localizada a cinqüenta quilômetros de Santo } \\
\text { Ângelo, sendo que o acesso se dá pela BR } 285\end{array}$ & $\begin{array}{l}\text { Sítio Arqueológico } \\
\text { Patrimônio Nacional }\end{array}$ \\
\hline
\end{tabular}




\begin{tabular}{|l|l|l|l|} 
& $\begin{array}{l}\text { abastecimento de água. Imagens do barroco } \\
\text { missioneiro, no museu do sítio arqueológico }\end{array}$ & e BR 466. & $\begin{array}{l}\text { (1938) } \\
\text { Patrimônio } \\
\text { Humanidade (1983) }\end{array}$ \\
\hline San Luis Gonzaga & $\begin{array}{l}\text { Onze estátuas do barroco-missioneiro que estão } \\
\text { localizadas na igreja matriz. Algumas peças } \\
\text { arqueológicas como pia batismal que integram o } \\
\text { acervo do museu municipal }\end{array}$ & $\begin{array}{l}\text { Localizada a sessenta quilômetros de Santo } \\
\text { Ângelo com acesso pela BR 285. }\end{array}$ & Sítio Arqueológico \\
\hline
\end{tabular}

Figura 26: quadro do Patrimônio Arquitetônico das Missões -BRASIL

Fonte:

\begin{tabular}{|l|l|l|l|}
\hline \multicolumn{1}{|c|}{ REDUÇÃO } & \multicolumn{1}{|c|}{ SITUAÇÃO DOS VESTIGIOS } & \multicolumn{1}{c|}{ CARACTERIZAÇÃO GERAL } & STATUS LEGAL \\
\hline San Ignácio Guazú & $\begin{array}{l}\text { Permanecem um dos lados da escola parte dos } \\
\text { altares e imaginária. O museu de arte religiosa de } \\
\text { arte Jesuítico localizasse no edifico das antigas } \\
\text { oficinas de artes do jesuitas. Quatro das antigas } \\
\text { habilitações são usada como museu. }\end{array}$ & $\begin{array}{l}\text { Localizado a cento e quarenta e quatro } \\
\text { quilômetros de Encarnacion seu acesso pela } \\
\text { Ruta 14 - Asunción - Encarnación }\end{array}$ & \\
\hline Santa Maria de Fé & $\begin{array}{l}\text { Permaneceram esculturas do periodo reducional. } \\
\text { Das edificaçes, nada sobrou. }\end{array}$ & $\begin{array}{l}\text { Localizado a cento e cinqüenta quilômetros de } \\
\text { Encarnacion. Acesso por quatorze quilômetros } \\
\text { por estrada sem asfalto pela Rota Principal. }\end{array}$ & \\
\hline Santa Rosa de Lima & $\begin{array}{l}\text { Permanece o campanário original e a } \\
\text { capela de Nostra Senhora Del Loreto com } \\
\text { os afrescos pintados em seus muros. }\end{array}$ & Localizada a cento e dezessete quilômetros de & \\
\hline
\end{tabular}




\begin{tabular}{|c|c|c|c|}
\hline & $\begin{array}{l}\text { Possui também esculturas que } \\
\text { representam a nunciação. }\end{array}$ & & \\
\hline Jesús de Tarvengue & Remanescentes da Igreja e do colégio antigo & $\begin{array}{l}\text { Localizado a quarenta quilometro de } \\
\text { encarnacion seu acesso se dá no KM } 12 \text { a } \\
\text { rodovia em Emcarnacion Cidad Del Lest. }\end{array}$ & $\begin{array}{l}\text { Patrimônio da } \\
\text { Humanidade. }\end{array}$ \\
\hline San Cosme y Damián & $\begin{array}{l}\text { Permanecem o colégio e antigas casa missioneiras } \\
\text { em uso. }\end{array}$ & $\begin{array}{l}\text { Localizada a setenta e quatro quilômetros de } \\
\text { Encarnacion sendo que seu acesso é dado por } \\
\text { um ramal de vinte quilômetros desde a Ruta } 1 \text {. }\end{array}$ & \\
\hline Santiago & $\begin{array}{l}\text { Permanecem paredes do antigo colégio e imagens } \\
\text { de Santiago San Brás e San Izidro }\end{array}$ & $\begin{array}{l}\text { Localizado acento e trinta e três quilômetros de } \\
\text { Encarnacion. }\end{array}$ & \\
\hline Santisima Trinidad & $\begin{array}{l}\text { Um doa conjuntos arquitetônicos mais completos, } \\
\text { permanece o "conjunto reducional" com as } \\
\text { edificações no entorno da praça como a igreja o } \\
\text { colégio, a casa dos índios }\end{array}$ & $\begin{array}{l}\text { Localizada a vinte e oito quilômetros de } \\
\text { Encarnacion, seu acesso e dá por la Ruta } \\
\text { Encarnacion - Ciuldad Del Este. }\end{array}$ & Patrimônio Humanidade \\
\hline $\begin{array}{l}\text { Nuestra Señora de } \\
\text { Itapuá }\end{array}$ & Não existem vestígios & & \\
\hline
\end{tabular}

Figura 27: quadro do patrimônio arquitetônico das missões - Paraguai

Fonte: 
Este patrimônio suscita a consciência de sua base comum e a necessidade de que os países que a integram assumam um compromisso solidário em prol de sua valorização e preservação o que pode ser dificultado porque, na prática, essas regiões ainda não contam com legislação específica A ação quando empreendida, tem partido dos governos nacionais que atuam no âmbito supranacional sobre suas respectivas regiões fronteirças ${ }^{20}$, tentando efetivar a integração local e regional.

Pelas grandes dificuldades econômicas pelas quais tem passado provocadas principalmente pelo fracasso da matriz produtiva regional, baseada na monocultura trigo-soja, os municípios que abrigam os sítios das antigas reduções jesuíticas vêem no turismo uma nova opção econômica baseada na riqueza e originalidade de seu patrimônio. Além do patrimônio remanescente do período jesuítico-guarani, têm procurado valorizar os demais elementos patrimoniais regionais, visando constituir-se em uma região turística. A mesma se caracteriza

como um espaço que atrai a demanda por constituir-se em um espaço individualizado em função de seus atributos físicos aliados às alterações sofridas no decorrer de sua evolução histórico-cultural. Sua singularidade é conferida pelo patrimônio natural e/ou cultural, forte motivo de atração de pessoas. (NOGUEIRA, 1999, p. 52).

\footnotetext{
${ }^{20}$ áreas junto à linha de fronteira (Rolim, 2004, p. 15)
} 


\title{
3 MISSÕES JESUÍTICO-GUARANI E DESENVOLVIMENTO REGIONAL: UM OLHAR PARA O FUTURO
}

Dos antigos "Trinta Povos das Missões" tem-se, hoje, cidades e povoados localizados em territórios de países distintos, mas que pela riqueza de seu patrimônio buscam através do resgate e valorização de uma história compartilhada, uma alternativa ao processo de desenvolvimento local e regional por meio da dinamização do turismo ${ }^{21}$. Essa dinamização vem assumindo importância crescente no mundo contemporâneo por desdobrar-se em uma diversidade de iniciativas e realizações que incidem sobre todos os setores da economia. Para Rodrigues o turismo é uma atividade complexa

\begin{abstract}
que compreende tanto a produção como o consumo, tanto as atividades secundárias (produção de espaço) como terciárias (serviços) que agem articuladamente, apropriando-se de 'lugares exóticos' de 'paisagens naturais' de 'paisagens históricas' transformando-os em lugares que deverão ser observados em lugares para se obter conhecimentos culturais, históricos, possibilitar o descanso, e vários outros motivos simbólicos ou reais (RODRIGUES, 1997, p 48).
\end{abstract}

Representando a busca de diferenças o turismo poderá contribuir para o

\footnotetext{
${ }^{21}$ Compreende as atividades que realizam as pessoas durante suas viagens e estadas em lugares diferentes ao seu entorno habitual, por um período consecutivo inferior a um ano, com finalidade de lazer, negócios ou outras. (SANCHO, 2001, )
} 
desenvolvimento endógeno, pela utilização do patrimônio local como bem de alto valor econômico; pelo estímulo às comunidades em termos de auto-estima e pela possibilidade de continuidade das propostas, independente de mudanças governamentais.(AZEVEDO, 2002,P.151)

Nesse sentido, o turismo poderá tornar-se um elemento "dinamizador" do processo de desenvolvimento local $^{22}$ e regional porque além de oferecer oportunidades de empregos diretos $\mathrm{e}$ indiretos $^{23}$ aumentando a renda da população local, por meio dos salários,"induz processos de valorização de recursos locais, assim como dinâmicas de renascimento cultural diversificada da qual se podem beneficiar tanto os turistas como os moradores." (VINUESA, 2004, p.37)

Dentre os elementos significativos para a atratibilidade turística pode-se dizer que o conhecimento das diferenças culturais existentes entre os povos constitui-se numa das mais importantes motivações das viagens turísticas. Richards destaca entre os produtos culturais mais utilizados pelo turismo:

sítios arqueológicos e museus; arquitetura e ruínas; artes visuais; artesanato, galerias, festivais e eventos em torno deles; música, dança clássica, folclórica e contemporânea; artes dramáticas (teatro, cinema); língua e literatura, na forma de cursos, seminários, feiras e outros eventos, festivais religiosos e

\footnotetext{
${ }^{22}$ Entendido como um processo de superação de problemas e conquista de condições (culturais, técnica - tecnológica, políticos-institucionais, espaços-temporais) propiciando maior felicidade individual e coletiva, o desenvolvimento exige a consideração simultânea das diversas dimensões constituintes das relações sociais (cultural, econômica, política) e também do espaço natural e social. (Souza, 2004, p. 18)

${ }^{23}$ Dias e Aguiar atentam para o fato de que estas oportunidades são sazonais, com níveis salariais mais baixos e dirigidos especialmente a jovens e mulheres (2002, p.148).
} 
peregrinações; a cultura popular e folclórica, e as subculturas urbanas (grafiti, rap), (apud GASTAL, 1999, p. 40),

itens ao qual a autora incluí ainda os parques temáticos e as manifestações étnicas.

Nesse contexto, o patrimônio que segundo Azevedo (2002, p. 134) "condensa a acumulação de bens herdados, construídos e/ou em construção e envolve o tempo tríblio, mesclando temporalidades diferentes: passado, presente e futuro", possui grande significado como potencialidade para o desenvolvimento do turismo porque

mais do que um testemunho do passado, o patrimônio é um retrato do presente, um registro das possibilidades políticas dos diversos grupos sociais, expressa na apropriação de parte da herança cultural, dos bens que materializam e documentam a sua presença no fazer histórico da sociedade. (RODRIGUES, 1996, p. 195)

Não se restringe à arquitetura, inclui outros pontos do sentir, do pensar e do agir humanos, sítios arqueológicos e objetos neles pesquisados, esculturas, pinturas, textos escritos, peças de valor etnológico, arquivos e coleções bibliográficas, desenhos de sentido artístico ou científico, peças significativas para o estudo da ergologia de um povo ou uma época. Tanto o patrimônio natural como o patrimônio cultural, apesar de apresentarem inúmeras possibilidades para o aproveitamento em atividades de turismo e lazer, não são usadas devidamente. O aproveitamento dos recursos da natureza e da cultura para as atividades turísticas poderão minimizar impactos ambientais e contribuir para o desenvolvimento, caso sejam planejadas e realizadas corretamente. Preservar o 
patrimônio é, portanto, investir no turismo - importante alternativa para a dinamização da economia local. (Pellegrini Filho, 1993)

Preservar as características de uma sociedade é manter conservadas as condições mínimas de sobrevivência, todas elas implícitas no meio ambiente e no saber que segundo Lemos (1996, p. 238), "é feito pelo patrimônio cultural que é constituído pelos elementos da natureza, o conhecimento e as técnicas - capacidade de sobrevivência do homem no seu ambiente (saber fazer)". Por isso, a conservação do patrimônio vem

tornando-se uma exigência social, posto que a população tornou-se mais consciente sobre o assunto, passou a entender que conservar os monumentos, as obras de arte, é uma questão de garantir a sobrevivência futura pois é essencial conhecermos as nossas raízes para garantir o progresso futuro. (MACHADO, 1992, p. 38)

Em âmbito mundial, os principais documentos que norteiam os trabalhos de movimentos de preservação patrimonial são os destacados no quadro que segue. 


\begin{tabular}{|l|l|}
\hline \multicolumn{1}{|c|}{ DOCUMENTOS } & \\
\hline $\begin{array}{l}\text { Carta de Atenas } \\
\text { de 1931 }\end{array}$ & $\begin{array}{l}\text { na qual o patrimônio é considerado como monumento de arte e história, } \\
\text { portanto, de interesse histórico, artístico e científico como bem documental } \\
\text { ou testemunho. }\end{array}$ \\
\hline $\begin{array}{l}\text { Resoluções de Haia } \\
\text { em 1954: }\end{array}$ & $\begin{array}{l}\text { o significado de patrimônio se amplia com o emprego do termo "bem cultural" } \\
\text { no qual estão incluídos os bens móveis e imóveis, tais como os monumentos } \\
\text { de arquitetura de arte ou de história, religiosos ou seculares, os sítios } \\
\text { arqueológicos, os grupos de construções que pelo seu conjunto ofereçam } \\
\text { um grande interesse histórico artístico ou arqueológico. }\end{array}$ \\
\hline $\begin{array}{l}\text { Carta de Veneza em } \\
\text { os conceitos da Carta de Atenas foram ampliados e reforçados sendo revisto } \\
\text { o conceito de monumento que passa a considerar não somente as grandes } \\
\text { criações, mas também as obras modestas que adquiriram com o tempo um } \\
\text { significado cultural, o patrimônio passa a ser visto como um testemunho vivo } \\
\text { de tradições seculares }\end{array}$ \\
\hline $\begin{array}{l}\text { Convenção de Paris } \\
\text { em 1972 }\end{array}$ & $\begin{array}{l}\text { além de instituir o Comitê Intergovernamental de Proteção do Patrimônio } \\
\text { Cultural e Natural, o Fundo para a Proteção do Patrimônio Mundial Cultural e } \\
\text { Natural, as Condições e Modalidades de Assistência internacional bem como } \\
\text { os Programas Educativos. De acordo com esta convenção, são } \\
\text { considerados patrimônio cultural os monumentos e os conjuntos que têm } \\
\text { valor universal excepcional do ponto de vista da história da arte ou da } \\
\text { ciência e, os lugares notáveis que possuem valor universal excepcional do } \\
\text { ponto de vista histórico, estético, etnológico ou antropológico }\end{array}$ \\
\hline
\end{tabular}

Figura 28: quadro sobre documentos os que norteiam a preservação patrimonial

Fonte: montado a partir de Kother (2001) e Pacheco (1994):

De acordo com Meneses (apud YÁZIGI, 2003) a cultura é uma condição de produção e reprodução da sociedade e nela os bens culturais possuem valores: cognitivos quando associados à possibilidade de conhecimento através de suas mais variadas formas; formais, com suas virtudes estéticas capazes de potenciar a "percepção sensorial"; afetivos que incluem as relações subjetivas de pertencimento e 
pragmáticas que se prestam ao uso altamente qualificado ou à criação tecnológica. Os valores dos bens é que qualificam e conferem singularidade ao patrimônio de uma comunidade, podendo ser aproveitado como produto cultural turístico.

Nesse sentido, as cidades que para Krause $(1999$, p. 68) "são locais onde se reúnem as maiores ofertas de negócios e lazer", representam significativos focos de atração turística porque nelas localizam-se uma boa densidade de artefatos diferenciadores e que para Waiberg (1999, p. 16) "constituem cultura no sentido pleno da palavra" e, por isso, nelas o turista busca "os elementos da paisagem, os espaços construídos e o movimento da vida" (op. cit. p.15). Já Gastal (1999, p. 34), destaca que "o turismo se constitui, historicamente pela busca do aprazível sendo que os turistas modernos percorrem as cidades em busca de um produto muito especial, a cultura".

A cultura é algo intrínseco ao ser humano, compreende a totalidade de suas criações. "Inclui idéias, valores, manifestações artísticas de todo tipo, crença, instituições sociais, conhecimentos científicos e técnicos, instrumentos de trabalho, tipos de vestuário, alimentação, construções, etc.." (DIAS E AGUIAR, 2002, p. 129) Constitui-se, conforme Azevedo (2002, p. 151) no código mais profundo que revela o modo de ser de uma sociedade forma-se numa "dimensão do processo da vida de uma sociedade. Não é estanque ou estável. É mutável e se vale das mais variadas formas de expressão humana". (TRIGO, 1993, p. 52) Para o autor, representa uma grande riqueza para as diferentes regiões, uma vez que o conhecimento da história, da arte, da vida e do modo de viver dos vários povos são importantes elementos de atratividade 
regional o que Castrogiovanni (1999, p. 32) reforça ao destacar que a coexistência de manifestações, documentos, agentes e processos, os mais dísparares ou similares possíveis, conferem à vida urbana diversidades; portanto, uma riqueza de possibilidades na oferta turística. Para Yázigi (2003) o urbano apesar de não ser o único espaço em que se pratica o turismo, é seguramente o mais importante porque para fins de se conhecer uma civilização, ele é o lugar por excelência do encontro social e cultural.

Na cidade a percepção é estimulada pelo estranhamento causado pela sua arquitetura, vias limites, bairros, pontos nodais, marcos, avenidas, cafés e bares. É uma obra de arte viva, e seus atores móveis são os seus habitantes. Há cores e odores. Hábitos e costumes. História e memória. ... A cidade é o lugar do olhar" (Wainberg,1999, p.11)

Para o autor, o olhar se fixa nas diferenças que poderão emocionar ou causar repulsa sendo elas a razão da visitação. São, portanto, as singularidades ou o "estranho" (para Wainberg), que embalado como produto é consumido através do turismo cultural ${ }^{24}$.

"Desponta como uma das vertentes mais significativas do desenvolvimento pela riqueza de variantes que comporta; pelas interfaces que motiva; pelos desdobramentos

\footnotetext{
${ }^{24}$ o turismo cultural promove a preservação da memória histórica e atua como elemento de continuidade que permite às comunidades se apropriarem do conhecimento de seus bens patrimoniais, e perceberem o correspondente valor econômico. (AZEVEDO, 2002, p. 154)
} 
que pode estimular; pelos efeitos possíveis na construção da cidadania; pela valorização da alteralidade, isto é, a compreensão da existência de outros patrimônios e ações culturais que, assim, como os nossos, merecem igual respeito. Também pelo retorno econômico que propicia e, sobretudo, pelo compromisso que assume com as gerações futuras".

Por envolver a apreciação do patrimônio histórico ${ }^{25}$, o turismo cultural poderá contribuir para a proteção e manutenção dos bens culturais das comunidades através do aumento da auto estima do residente e do aumento da consciência do visistante que busca conhecer as características singulares de outros povos, promovendo ampla apreciação cultural. Por isso

a preservação dos bens culturais e as ações ligadas à cultura, como: a promoção da identidade local, das línguas regionais e das culturas minoritárias; a valorização do patrimônio local, através da criação de itinerários culturais; a valorização dos conhecimentos especializados tradicionais como o artesanato artístico; a criação de infra-estrutura cultural permanente (centros culturais, ecomuseus); a organização de atividades culturais mais pontuais como animação e difusão cultural, cinemas itinerantes e festivais (LEADER apud NOGUEIRA, 1999, p.68)

contribuem, para potencializar as peculiaridades culturais regionais aumentando sua atratibilidade.

${ }^{25}$ Expressão que designa um bem destinado ao usufruto de uma comunidade que se ampliou a dimensões planetárias, constituído pela acumulação contínua de uma diversidade de objetos que se consagram por seu espaço comum: obras e obras primas das belas artes e das artes aplicadas, trabalhos e produtos de todos os saberes e savoir faire dos seres humanos. (CHOAY, 2001, p. 11) 


\subsection{PATRIMÓNIO ARQUITETÓNICO DA REGIÃO DAS MISSÕES E SUA IMPORTÂNCIA TURISTICA.}

Localizado em uma região transfronteiriça, o conjunto patrimonial da Região das Missões Jesuítico-Guarani engloba remanescentes dos antigos "Trinta Povos das Missões", dentre os quais sete foram tombados pela Unesco como Patrimônio Histórico da Humanidade ${ }^{26}$ São Miguel onde destaca-se o templo da antiga redução (figura 29), no Brasil; São Ignácio onde evidencia-se o conjunto da igreja, colégio, casa dos padres, oficina e cemitério além das portadas (figuras 30,31), Santa Ana com ênfase aos muros do colégio, das oficinas e da quinta (figura 32), Loreto onde se vê as paredes da igreja em meio à vegetação (figura 33) e Santa Maria onde vê-se parte dos muros do colégio (figura 34) na Argentina; Jesús cuja igreja foi reconstituída (figura 35) e Trinidad que possui um dos mais completos conjuntos da estrutura da redução (figura 36) no Paraguai. De acordo com Barbacci e Gremertieri (2004-5, p.19) O mesmo é constituído por bens culturais "imóveis, móveis, materiais ${ }^{27}$ e imateriais ${ }^{28}$ de grande significado histórico e cultural para as cidades, estados e países onde se localizam".

\footnotetext{
${ }^{26}$ Caracterizado pela presença de bens que são excepcionais quase sempre por sua história, sua beleza e por sua originalidade. (MOREL, 1996, p. 78)

${ }^{27}$ Refere-se aos aspectos físicos ou tecnológicos de nossas vidas diárias, inclusive a comida, casas, fábricas, vestuário, transportes e matérias-primas. (DIAS e AGUIAR, 2002, p. 130)

${ }^{28}$ Refere-se aos modos de usar os objetos materiais, aos costumes, as crenças, filosofias, governos e padrões de comunicação. (DIAS e AGUIAR, 2002, p. 130)
} 


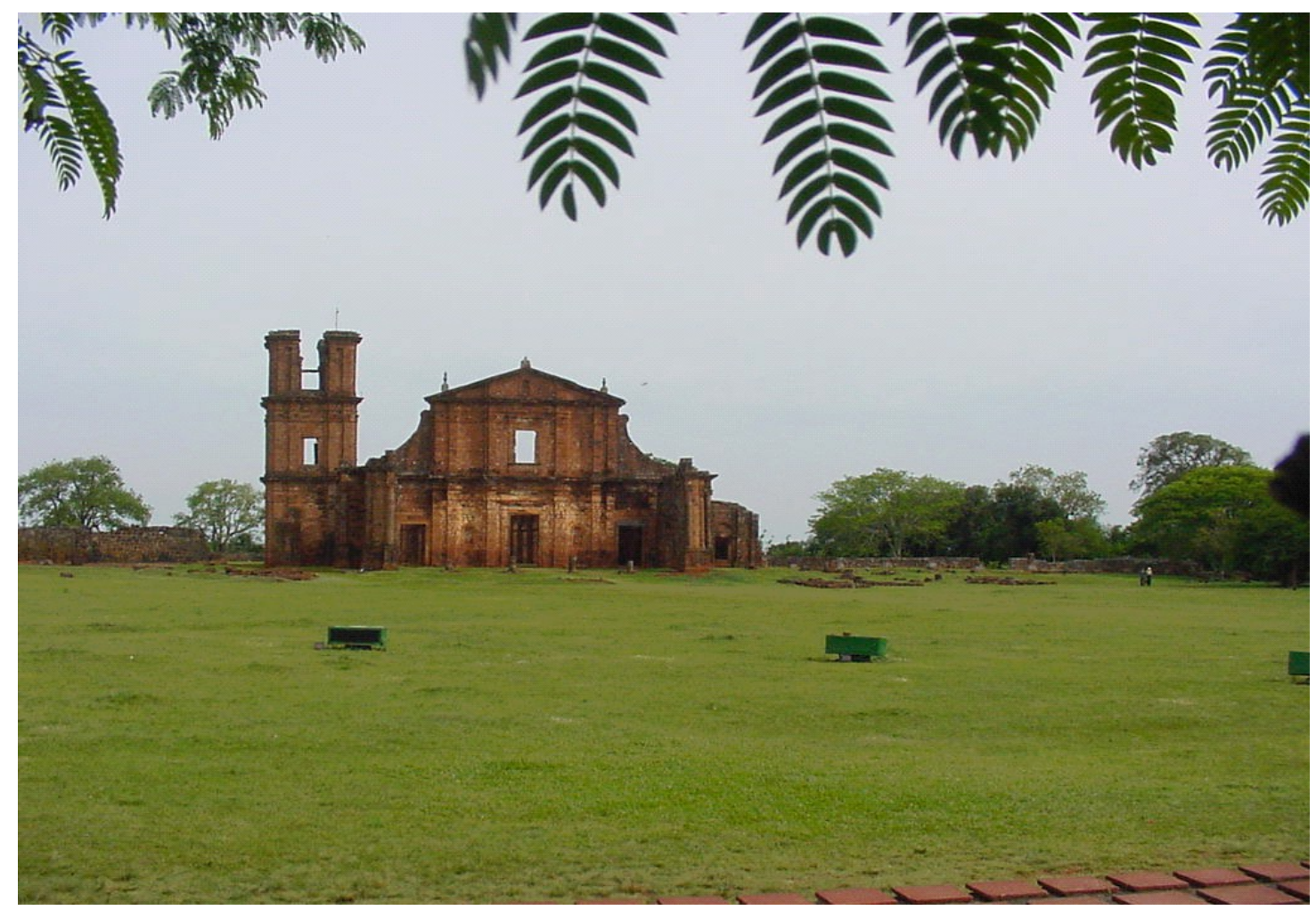

Figura 29: foto do Sítio Arqueológico de São Miguel - Brasil

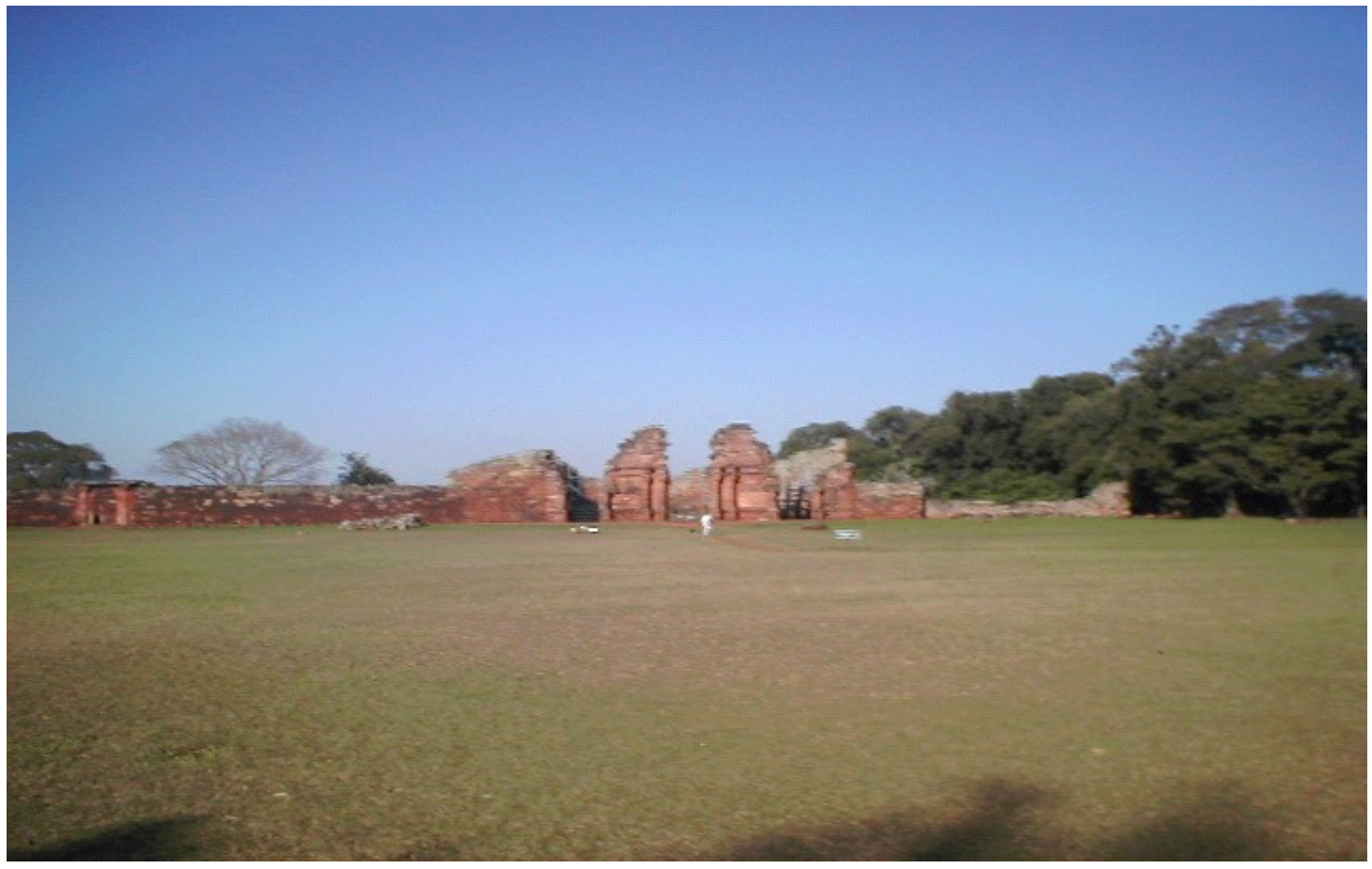

Figura 30: foto do Sítio Arqueológico de San Ignácio Mini - Argentina 


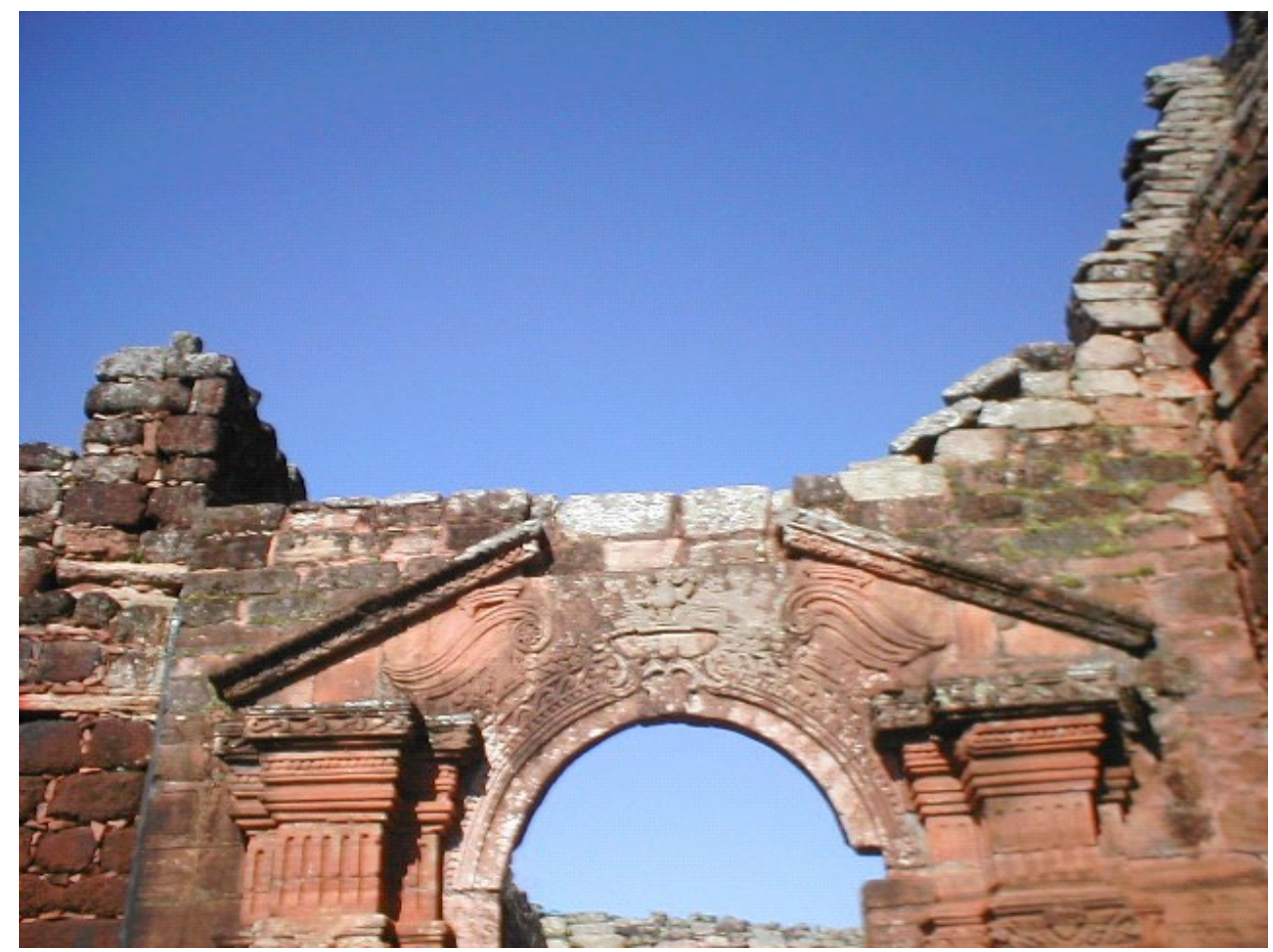

Figura 31:foto do Sítio Arqueológico de San Ignácio Mini- Argentin

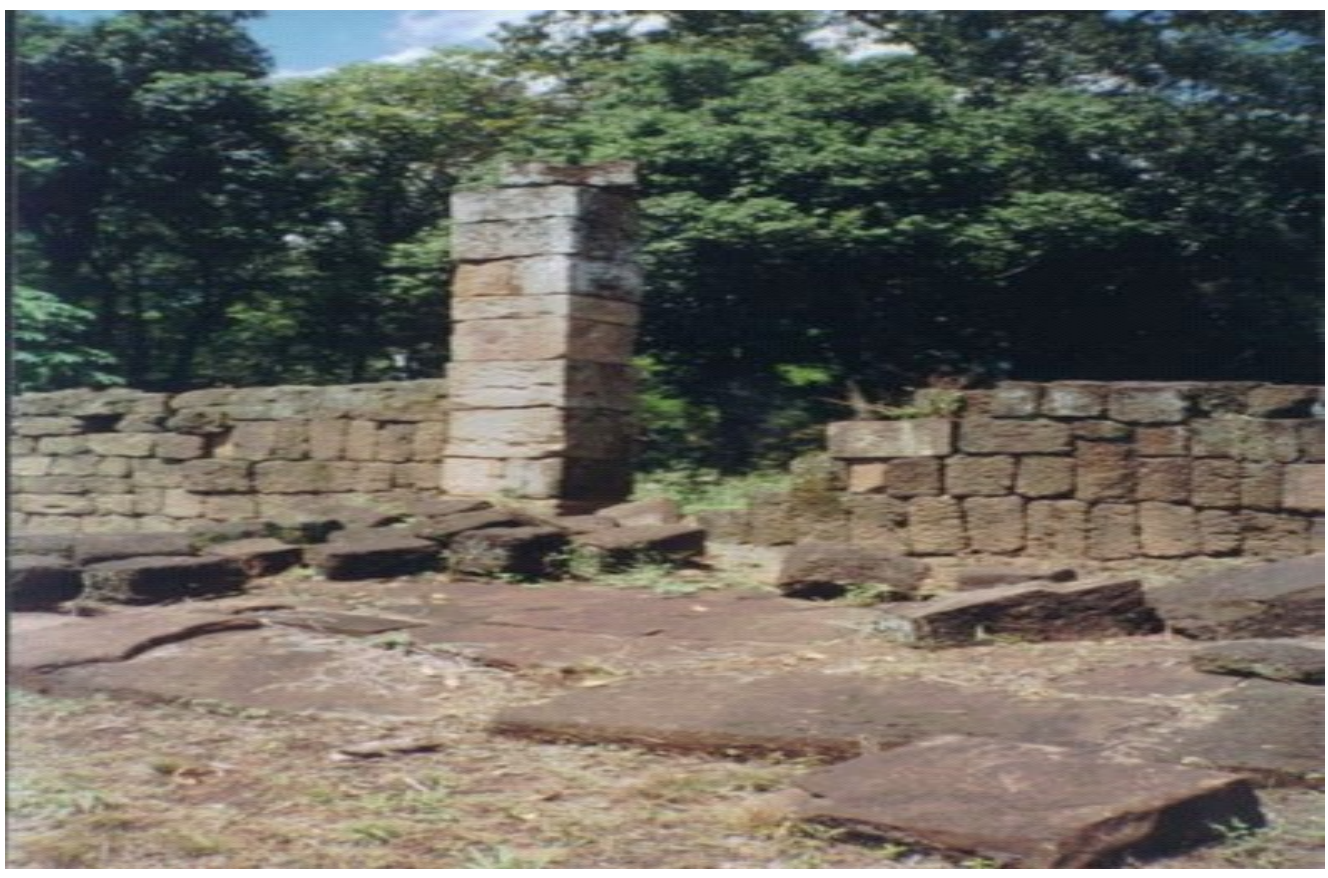

Figura 32: foto do Sito Arqueológico de Santa Ana - Argentina 


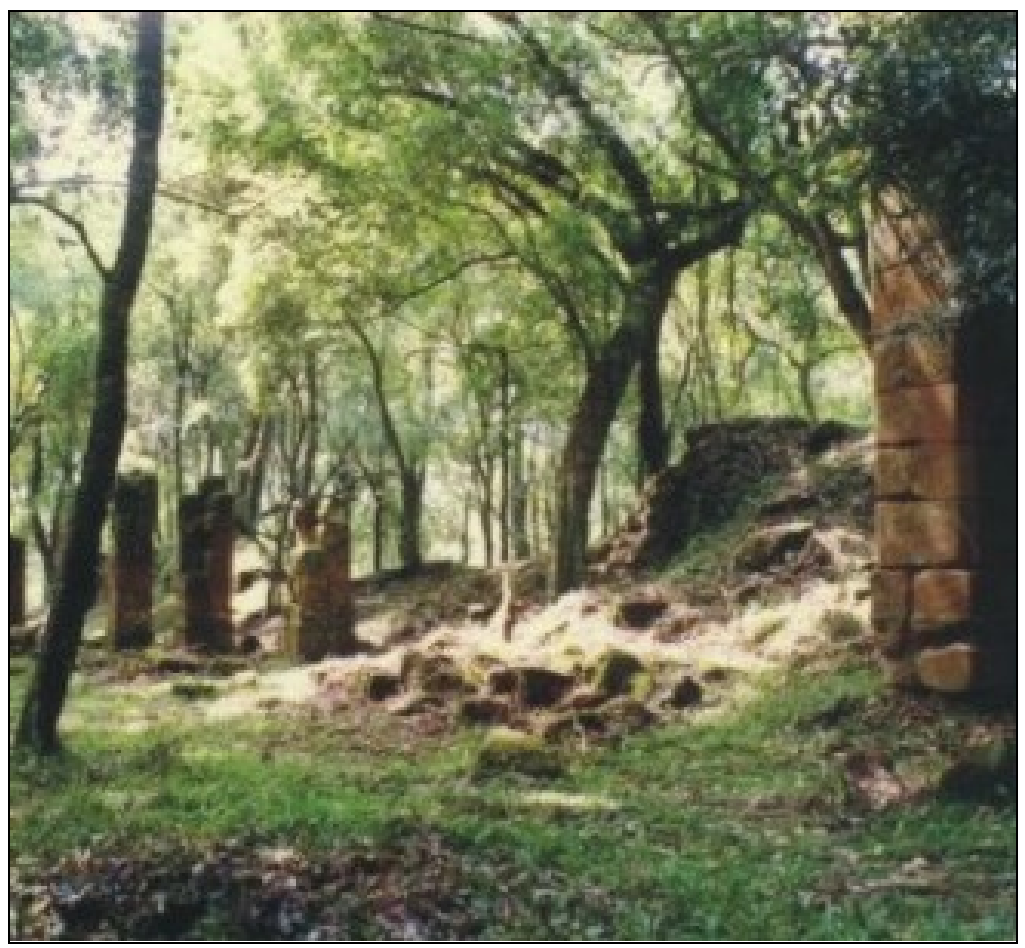

Figura 33: foto do Sito Arqueológico de Loreto- Argentina

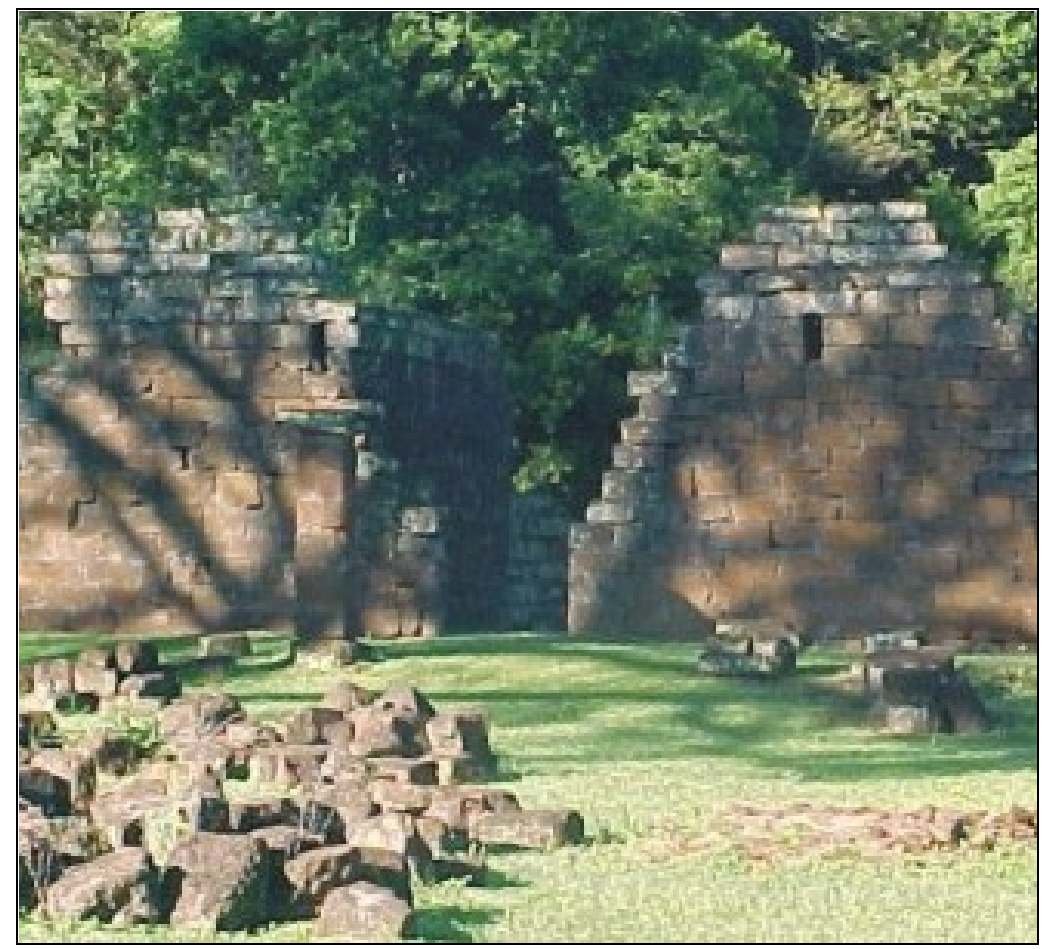

Figura 34:foto do Sito Arqueológico de Santa Maria-Argentina 


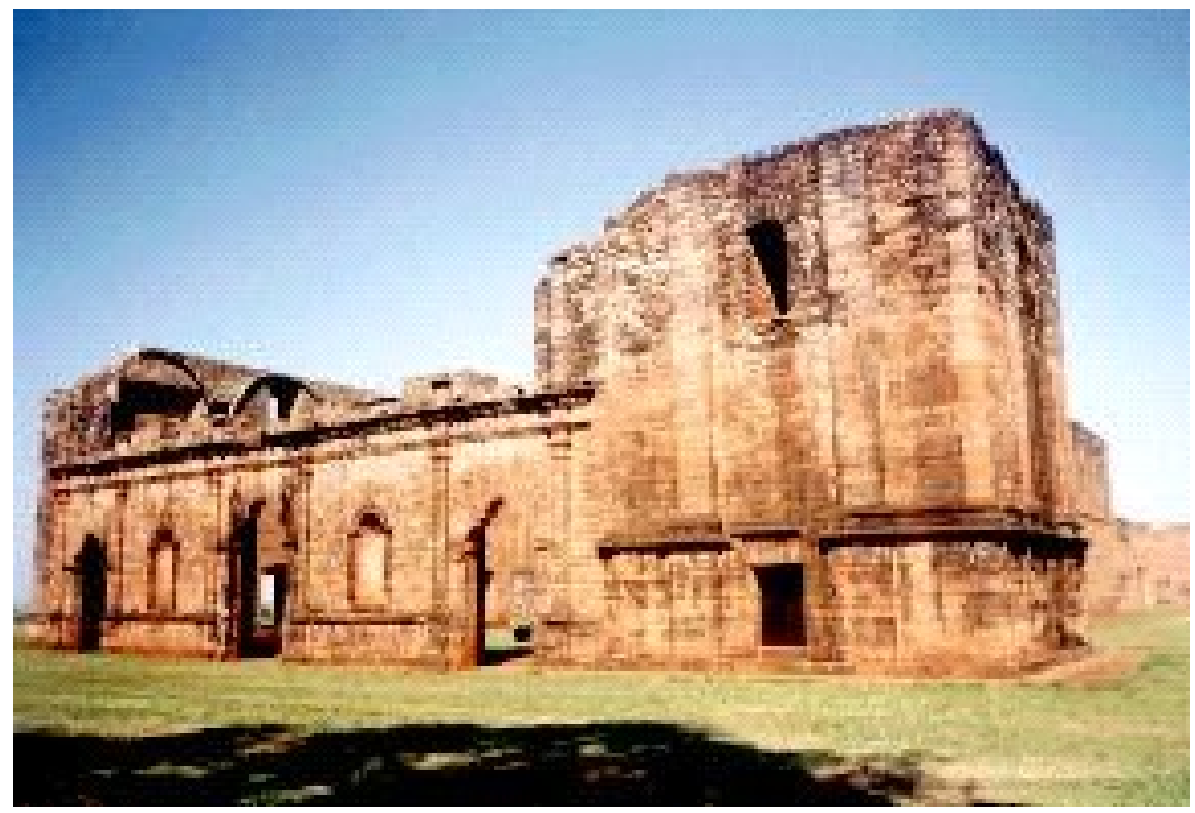

Figura 35: foto do Sítio Arqueológico de Jesus - Paraguai

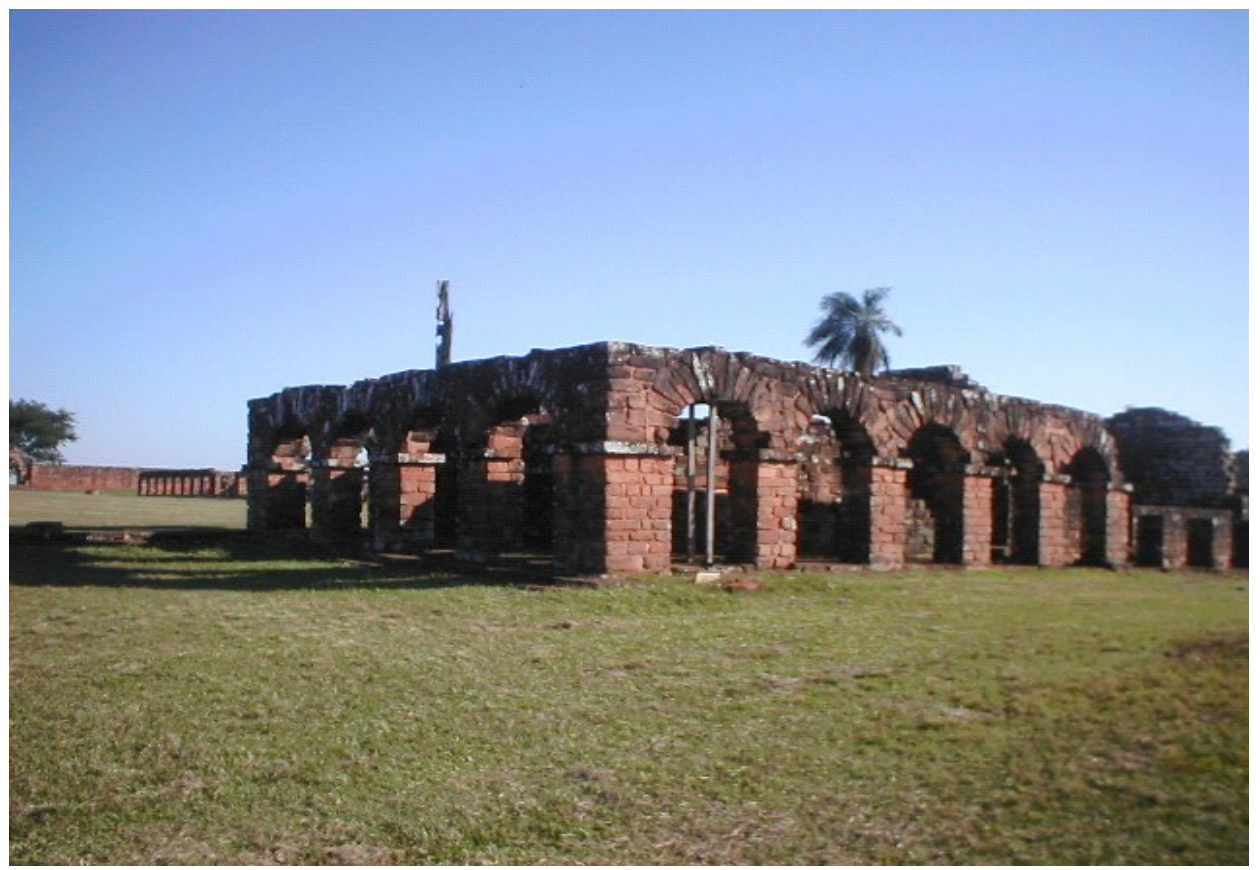

Figura 36: foto do Sítio Arqueológico de Trinidad - Trinidad 
A declaração de um bem como patrimônio da humanidade cria uma imagem em âmbito internacional que atrai visitantes com interesses diversos podendo ser de cunho científico ou puramente relacionado ao ócio. (MOREL, 1996) Seu valor está na

combinação das características materiais dos bens, na geografia cultural, gerada, no que representa em um período específico e transcendente da história, em que vários países compartilhavam um processo particular e as manifestações materiais que ficaram como seu testemunho. (Mujica 2004-5, p. 21)

Integram o patriônio regional o conjunto de remanescentes da cultura Jesuítico-

\section{Guarani que}

condensam muito mais do que pedras gravadas ou peças arquitetônicas, são um resumo do trabalho infatigável e os sonhos de missioneiros Jesuítas e Guaranis de desenvolver uma cultura própria e plena e que, somada a cada particular desenvolvimento dos atuais Trinta Povos, oferecem um recurso cultural e turístico único para a região que abrange estes países irmãos. (NEGRETE, 2005, p.5)

Nesse sentido, o patrimônio regional desempenha a importante função de manter a identidade de uma comunidade para as futuras gerações.

Testemunhos materiais de um episódio singular podem ser considerados de mesmo valor que outros monumentos arquitetônicos americanos que podem ser utilizados por historiadores e outros estudiosos como importantes documentos para pesquisa. Podem também, servir como suporte didático para $o$ ensino $e$ aprendizagem de crianças $e$ adultos.(Damiani,2004, p. 43) 
Sua preservação reveste-se de fundamental importância especialmente se for aproveitado para fins turísticos-recreacionais, requerendo ações de diferentes setores da comunidade como o setor público, o setor privado e comunidade em geral.Para Nagel

A memória da história missioneira faz parte da herança cultural, não só dos habitantes atuais das regiões onde existem os remanescentes, mas de todo o sul da América, sendo uma das raízes das culturas regionais que influenciam e realimentam a música, a literatura, o teatro, cinema e artes em geral. (NAGEL, 2001, p 47)

A visitação a esses remanescentes destacados nos quadros $X<Y<Z$ permitem conforme Kern (2002, p.1) "realizarmos uma viagem ao passado cultural", "possibilitando ver o esplendor e o apogeu da civilização que teve ali lugar" (PESAVENTO, 2006, p. 2) Para o autor anteriormente citado, quando visitamos

os remanescentes dos povoados missioneiros, podemos compreender melhor a importância dos episódios desta história de longa duração das Missões Jesuítico-Guaranis. Sua valorização como patrimônio histórico e cultural, comum a todos os povos da região, se impõe com toda a importância histórica que merecem. Mais do que uma referência histórica para as atuais populações que os visitam, esses "Pueblos de Índios" coloniais são um só símbolo para a integração cultural de toda a região. (KERN, 2002, p.1)

Assim, o patrimônio constitui-se numa grande potencialidade para o desenvolvimento do turismo regional porque as peculiaridades de seus sítios despertam 
a curiosidade de inúmeros visitantes, "representando uma das principais atividades educacionais do tipo informal, difusor da cultura integracionista" (TONINI, MATTHEUS E CAMARGO 2001, p 87), salvaguardando sua identidade cultural além de atender as exigências do turismo.Dessa forma "parece não restarem dúvidas sobre a evidência do interesse que patrimônio natural e patrimônio cultural oferecem não somente ao turismo, mas em primeiro lugar para as próprias coletividades". (Pellegrini Filho, 1993, pág. 140)

O conjunto de remanescentes arquitetônicos que dá originalidade à Região das Missões apresenta características diferenciadas em relação ao status legal, situação dos vestígios bem como do uso público que se faz do mesmo (figura25-27). Para Hoff (2004, p. 11) o conjunto patrimonial encontra-se fragmentado "tanto em seu aspecto institucional de gestão, como nos aspectos técnicos de intervenção e conservação" porque se localiza hoje, em territórios pertencentes a distintos países sendo que estes, para Santos (apud SILVEIRA, 2003, p. 37) é que constituem o traço de união entre o passado e o futuro imediatos. Em razão desta fragmentação faz-se necessária uma intervenção integrada do patrimônio para sua "conservação e melhoria em sua gestão possibilitando que a região seja beneficiada com o seu uso público e com um plano de desenvolvimento solidamente construído".(BARBACCI, 2005, p. 15)

Enquanto materialidade que exibe o que restou, os remanescentes arquitetônicos constituem 
uma presença do tempo escoado, objetivada no espaço construído possibilitam uma viagem tanto no tempo como no espaço, quanto no interior do indivíduo, conduzindo às reflexos íntimas sobre o sentido da existência ... A materialidade da pedra das antigas reduções evoca a existência de muitas lutas, de missionários e guaranis contra os bandeirantes preadores de índios, no século $\mathrm{XVII}$, antes mesmo do erguimento daquelas obras, agora em ruínas ou dos embates entre os mesmos padres e índios missioneiros contra os exércitos luso-espanhóis, no século XVIII, na seqüência da demarcação do Tratado de Madrid que deu origem à chamada Guerra Guaranítica. (PESAVENTO, 2006, p.8)

Esse relevante patrimônio presente na Região das Missões, não deve ser visto apenas como um recurso econômico. É preciso ver no turismo histórico-cultural "uma atividade em que se processa e intensifica-se a realização de uma essência humana, de uma relação dos homens com a humanidade através de espaços e tempos mais amplos e mais diversos" (CARVALHO, 1996, p. 109) Sua grande significação é destacada nas palavras de Portugez (2004, p.4):

a visita a um sítio histórico representa uma viagem no tempo, que permite ao contemplador da paisagem uma experiência de contato emocional e físico com inúmeros equipamentos que remontam seu passado, dando mais sentido à história de sua vida, de sua família, de sua comunidade e mesmo de seu país. 


\subsection{Projetos, Programas e Políticas Voltados ao Turismo Regional.}

Imbuídos do espírito integracionista e convencidos da capacidade que possui a atividade turística para promover o desenvolvimento local e regional, os países nos quais estão localizados os diferentes sítios dos antigos Trinta Povos têm procurado desenvolver projetos de dinamização deste setor porque:

Quando é exitosa a organização do turismo em torno do Patrimônio Histórico gera-se toda uma economia com ramificações além do domínio que resulta no desenvolvimento sócio-econômico, a partir do consumo e uso-fruto do bem cultural constituído pelo patrimônio Histórico". (KOTHER, 2001, p. 110)

Assim, ao longo dos últimos anos, muitos projetos e programas voltados para o turismo tem sido propostos, com o intuito de "alavancar" o desenvolvimento regional. Dentre eles, pode-se destacar os que seguem:

\subsubsection{Circuito Internacional das Missões Jesuíticas}

Implantado em outubro de 1995 e integrado por territórios pertencentes à Argentina, ao Brasil, ao Paraguai e ao Uruguai (figura 37), constitui-se no produto turístico cultural mais importante do Mercosul e foi considerado pela Unesco como um dos principais roteiros históricos internacionais do mundo, ao lado da Rota das Sedas na Ásia, da Rota Escrava no Caribe e do Mundo Maia na América Latina. Isto se deve ao seu rico patrimônio cultural, representado principalmente pelos remanescentes arquitetônicos das antigas Reduções Jesuíticas-Guarani onde se localizam importantes Patrimônios Culturais da Humanidade: São Miguel das Missões no Brasil, San Ignácio, 
Santa Ana, Santa Maria e Loreto, na Argentina; Trinidad e Jesús no Paraguai, além da Colônia de Sacramento no Uruguai. A inclusão da Colônia de Sacramento, na prática, deu-se apenas pela obrigatoriedade da participação dos quatro países integrantes do Mercosul. Devido à grande distância existente entre Colônia e a Região das Missões, dificilmente o turista visita as duas localidades. Sua configuração é resultado de estudos realizados pelo Sub-Grupo 13 do Grupo Mercado Comum, órgão executivo do Mercosul, e é considerado como um dos fatores mais importantes para o desenvolvimento e a integração regional, uma vez que a cultura desempenha destacado papel nas aproximações políticas, sociais e econômicas.

Dentre os principais objetivos deste circuito Nogueira (1999) destaca: divulgação da História dos Trinta Povos Missioneiros; resgate das obras realizadas pela comunidade jesuítico-guarani; consolidação da região como pólo turístico internacional; resgate e transmissão dos valores culturais e regionais às futuras gerações; valorização e preservação do patrimônio regional; e, principalmente, constituir-se em uma alternativa para o desenvolvimento regional, uma vez que seus territórios constituem-se em espaços periféricos em relação a seus respectivos centros nacionais, passando por séria crise econômica. Seu roteiro e suas principais características podem ser observadas na figura 38. 


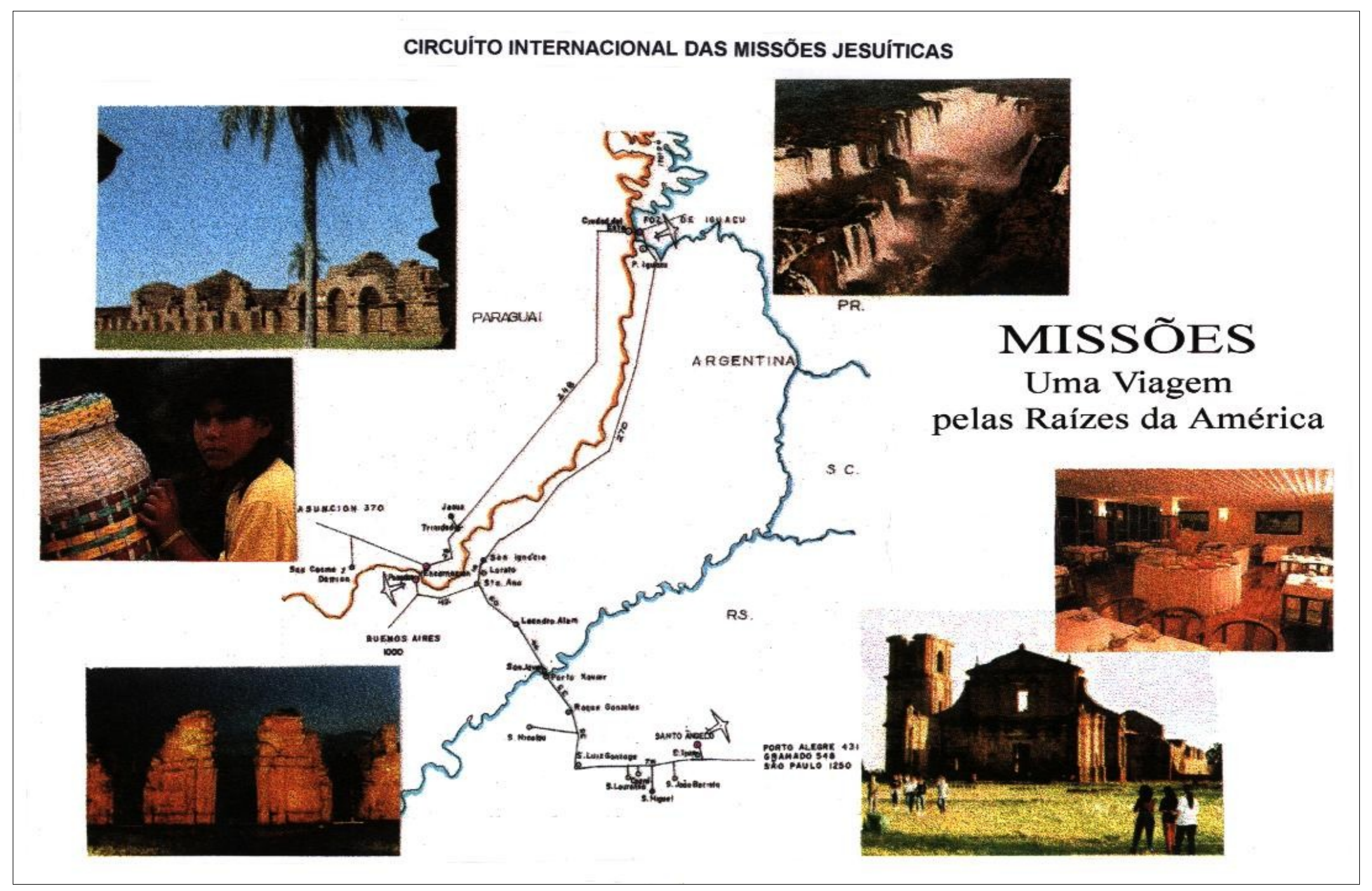

Figura 37: mapa do Circuito Internacional das Missões Jesuíticas 


\begin{tabular}{|c|c|c|c|}
\hline Local & Atrativos & Infra-estrutura & OBS \\
\hline $\begin{array}{l}\text { Santo Ângelo } \\
\text { (Brasil) }\end{array}$ & $\begin{array}{ll}\text {. } & \text { Catedral Angelopolitana } \\
\text {. } & \text { Memorial Prestes } \\
\text {. } & \text { Monumento do Col.Verzeri Índio Missioneiro } \\
\text {. } & \text { Museus:Dr. José Olavo Machado, } \\
& \text { Mal. Rondon. } \\
\text { Centro de Cultura Missioneira } \\
\text { Pesque e Pague. } \\
\text { Prefeitura Municipal. } \\
\text { Centro de Tradições } \\
\text { Gaúchas } \\
\text { Praça Pinheiro Machado. } \\
\text { Rua } 3 \text { de Maio. } \\
\text { URI } \\
\text { Centro Municipal de Cultura. } \\
\text { A.A.P.A.S.A. e Brique da Rio Branco. } \\
\text { Calçadão da } 25 . \\
\text { Shopping das Fábricas. }\end{array}$ & $\begin{array}{l}\text { Bons hotéis. } \\
\text {. } \\
\text { Rede gastronômica boa. } \\
\text { POA e SP. } \\
\text { Expressivo } \mathrm{n}^{\circ} \text { de rede de } \\
\text { linhas e empresas de } \\
\text { transporte. } \\
\text { Serviço de guias. }\end{array}$ & $\begin{array}{l}\text { Considerada a } \\
\text { "Capital das } \\
\text { Missões". } \\
\text { Dista } 460 \mathrm{Km} \text { de } \\
\text { Porto Alegre. }\end{array}$ \\
\hline $\begin{array}{l}\text { São Miguel } \\
\text { (Brasil) }\end{array}$ & 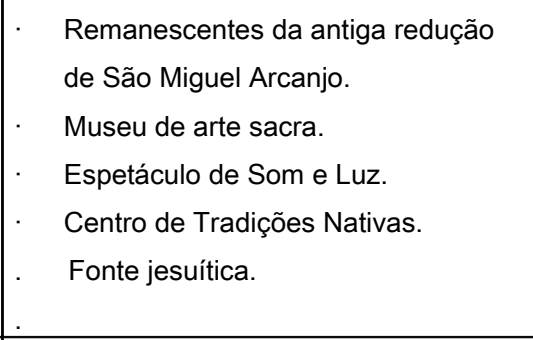 & 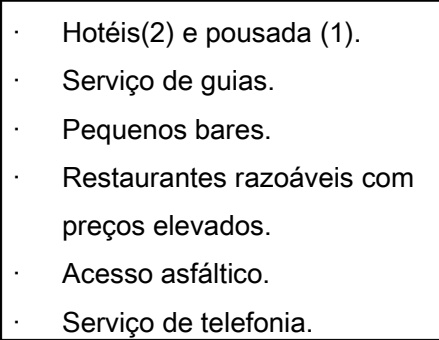 & $\begin{array}{l}\text { - Patrimônio Histórico e } \\
\text { Cultural da } \\
\text { Humanidade. } \\
\text { Dista } 58 \mathrm{Km} \text { de Santo } \\
\text { Ângelo. }\end{array}$ \\
\hline $\begin{array}{l}\text { São João Batista } \\
\text { (Brasil) }\end{array}$ & $\begin{array}{l}\text { Remanescente do antigo povoado. } \\
\text {. } \quad \text { Monumento ao Padre Antonio Sepp. } \\
\text { Exposição de fotos e videos. }\end{array}$ & $\begin{array}{l}\text { Praticamente inexistente } \\
\text { Acesso com } 6 \mathrm{Km} \text { de estrada } \\
\text { não pavimentada. }\end{array}$ & $\begin{array}{l}1^{\text {a }} \text { fundição de ferro e } \\
\text { aço do sul do País. } \\
\text { Dista } 28 \mathrm{~km} \text { de Santo } \\
\text { Ângelo. }\end{array}$ \\
\hline $\begin{array}{l}\text { Santuário de } \\
\text { Caaró } \\
\text { (Brasil) }\end{array}$ & $\begin{array}{l}\text { Santuário. } \\
\text { Fonte "milagrosa". }\end{array}$ & $\begin{array}{l}\text { Casas de retiro-hospedagem } \\
\text { para grupos religiosos e } \\
\text { população de baixa renda. } \\
\text {. Área de camping. }\end{array}$ & $\begin{array}{l}\text {. Fonte de água } \\
\text { mineral " milagrosa”. } \\
\text { Dista } 40 \mathrm{Km} \text { de Santo } \\
\text { Ângelo. }\end{array}$ \\
\hline $\begin{array}{l}\text { São Lourenço } \\
\text { (Brasil) }\end{array}$ & Remanescentes do antigo povoado. & $\begin{array}{l}\text { Praticamente inexistente. } \\
\text { Acesso com } 6 \mathrm{Km} \text { de estrada } \\
\text { não pavimentada. }\end{array}$ & $\begin{array}{l}\text { Bastante degradado. } \\
\text { Dista } 50 \mathrm{~km} \\
\text { de Santo Ângelo } \\
\end{array}$ \\
\hline $\begin{array}{l}\text { São Luiz Gonzaga } \\
\text { (Brasil) }\end{array}$ & $\begin{array}{ll}\text {. } & \text { Igreja Matriz. } \\
\text { Museu Municipal Senador } \\
\text { Pinheiro Machado } \\
\text {. } & \text { Museu Arqueológico. } \\
\text {. } & \text { Gruta N.S Lourdes. }\end{array}$ & $\begin{array}{l}\text { Hotéis não classificados (3). } \\
\text {. } \quad \text { Restaurantes. }\end{array}$ & $\begin{array}{l}\text { Importante acervo de } \\
\text { escultura missioneira. } \\
\text { Dista } 60 \mathrm{~km} \text { de Santo } \\
\text { Ângelo }\end{array}$ \\
\hline
\end{tabular}




\begin{tabular}{|c|c|c|c|}
\hline $\begin{array}{l}\text { São Nicolau } \\
\text { (Brasil) }\end{array}$ & $\begin{array}{l}\text {. } \quad \text { Remanescentes do antigo povoado. } \\
\text {. } \quad \text { Museu Municipal. } \\
\text {. Passo de Santo Izidro. }\end{array}$ & $\begin{array}{l}\text { Hotel não classificado. } \\
\text { Restaurante. } \\
\text { Acesso com } 15 \mathrm{~km} \text { de estrada } \\
\text { pavimentada. }\end{array}$ & $\begin{array}{l}\text { Remanescentes } \\
\text { integrados à área } \\
\text { urbana atual. } \\
\text { Dista } 120 \text { km } \\
\text { de Santo Ângelo. }\end{array}$ \\
\hline $\begin{array}{l}\text { San Ignácio } \\
\text { (Argentina) }\end{array}$ & $\begin{array}{l}\text { Remanescentes da antiga redução. } \\
\text { Espetáculo Som e Luz. } \\
\text { guarani } \\
\text {. Casa do escritor Horacio Quiroga. } \\
\text { Clube de caça e pesca. } \\
\text {. } \quad \text { Museu Miguel Nadasdy } \\
\text {. Cerro Rainha Vitória }\end{array}$ & $\begin{array}{l}\text { Hospedarias e hotéis . } \\
\text { Restaurantes. } \\
\text { Serviço de guias. } \\
\text { Artesanato expressivo } \\
\text { Bons locais para camping }\end{array}$ & $\begin{array}{l}\text { Patrimônio Histórico e } \\
\text { Cultural da } \\
\text { Humanidade. } \\
\text { Dista } 60 \text { km de } \\
\text { Posadas. }\end{array}$ \\
\hline $\begin{array}{l}\text { Santa Maria } \\
\text { (Argentina) }\end{array}$ & $\begin{array}{l}\text { Remanescentes da Antiga Redução. } \\
\text { Centro de atendimento e apoio ao } \\
\text { turista. }\end{array}$ & Praticamente inexistente. & $\begin{array}{l}\text { Patrimônio da } \\
\text { Humanidade. } \\
\text { Dista } 20 \mathrm{Km} \text { da } \\
\text { divisa do Brasil } \\
\text { (Porto Xavier). }\end{array}$ \\
\hline Loreto (Argentina) & $\begin{array}{l}\text { Remanescentes da antiga redução. } \\
\text { Centro de atendimento ao turistapoio }\end{array}$ & Inexistente. & $\begin{array}{l}\text { Bastante degradado. } \\
\text { Local da } \\
\text { primeira im- } \\
\text { prensa cons- } \\
\text { truída pelos } \\
\text { jesuítas. } \\
\text { Dista } 40 \mathrm{Km} \mathrm{de} \\
\text { Posadas. }\end{array}$ \\
\hline $\begin{array}{l}\text { Santa Ana } \\
\text { (Argentina) }\end{array}$ & $\begin{array}{l}\text { Remanescentes da antiga redução. } \\
\text { Cerro Santa Ana. } \\
\text { Balneário municipal. } \\
\text {. Pesca esportiva. } \\
\text { Centro de interpretação } \\
\text { e apoio. } \\
\text { Fábrica artesanal de } \\
\text { rapadura. }\end{array}$ & $\begin{array}{l}\text { Inexistente. } \\
\text { Acesso com } 2 \mathrm{~km} \text { de estrada } \\
\text { não pavimentada. }\end{array}$ & $\begin{array}{l}\text { Dista a } 45 \mathrm{~km} \text { de } \\
\text { Posadas. } \\
\text { Bastante degradado. }\end{array}$ \\
\hline
\end{tabular}




\begin{tabular}{|c|c|c|c|}
\hline $\begin{array}{l}\text { Posadas } \\
\text { (Argentina) }\end{array}$ & $\begin{array}{l}\text { Cassinos. } \\
\text { Rio Paraná. } \\
\text { Museus: Policial, Arqueoló- } \\
\text { gico, de Arte, de Ciências } \\
\text { Naturais e História, } \\
\text { Centro Cultural. } \\
\text { Mercado Municipal. } \\
\text { Mercado das Villenas. } \\
\text { Mercado de artesanato. } \\
\text { Ponte sobre o rio Paraná- } \\
\text { São Roque Gonzales de } \\
\text { Santa Cruz. } \\
\text { Catedral. } \\
\text { Balneário. } \\
\text { Hipódromo. } \\
\text { Jardim Botânico. } \\
\text { Porto. } \\
\text { Casas noturnas. }\end{array}$ & $\begin{array}{l}\text { Muito boa. Bons hotéis e } \\
\text { restaurantes. } \\
\text { Dois aeroportos, um } \\
\text { internacional. } \\
\text { Vias de acesso às várias } \\
\text { regiões do país e países } \\
\text { vizinhos. }\end{array}$ & $\begin{array}{l}\text { Dista } 265 \mathrm{Km} \text { de } \\
\text { Santo Ângelo. } \\
\text { Segunda cidade da } \\
\text { Argentina. }\end{array}$ \\
\hline $\begin{array}{l}\text { Encarnación } \\
\text { (Paraguai) }\end{array}$ & $\begin{array}{l}\text { Zona florestal. } \\
\text { Rio Paraná . } \\
\text { Balneários. } \\
\text { Sítios de pesca. } \\
\text { Área de livre comércio. } \\
\text { Ponte sobre o Rio Paraná- } \\
\text { São Roque Gonzales de } \\
\text { Santa Cruz. } \\
\text { Praça das Armas } \\
\text { Centro de desenvolvimento } \\
\text { comunitário. } \\
\text { Casa de Cultura. } \\
\text { Igreja Ortodoxa Russa. }\end{array}$ & $\begin{array}{l}\text { Bons hotéis. } \\
\text { Bons restaurantes. }\end{array}$ & $\begin{array}{l}\text { Dista } 280 \text { Km de } \\
\text { Santo Ângelo e } 380 \\
\text { Km de Assunción. } \\
\text { Segunda cidade do } \\
\text { Paraguai. }\end{array}$ \\
\hline $\begin{array}{l}\text { Trinidad } \\
\text { (Paraguai) }\end{array}$ & Remanescentes da antiga redução. & $\begin{array}{l}\text { Praticamente inexistente. } \\
\text { Pequenos hotéis, } \\
\text { albergues e camping. }\end{array}$ & $\begin{array}{l}\text { Patrimônio Histórico } \\
\text { da Humanidade. Bom } \\
\text { estado. } \\
\text { Dista 28km Encarnación. }\end{array}$ \\
\hline $\begin{array}{l}\text { Jesús } \\
\text { (Paraguai) }\end{array}$ & $\begin{array}{l}\text { Remanescentes da antiga redução. } \\
\text { Centro de atenção ao turista }\end{array}$ & $\begin{array}{l}\text { Praticamente inexistente. } \\
\text { Serviço de guia. } \\
\text { Acesso com } 10 \mathrm{~km} \text { de estrada } \\
\text { não pavimentada }\end{array}$ & $\begin{array}{l}\text { Patrimônio Histórico e } \\
\text { Cultural da } \\
\text { Humanidade. Bom } \\
\text { estado. } \\
\text { Dista 35km de } \\
\text { Encarnación. }\end{array}$ \\
\hline
\end{tabular}




\begin{tabular}{|c|c|c|c|}
\hline $\begin{array}{l}\text { Colônia de } \\
\text { Sacramento } \\
\text { (Uruguai) }\end{array}$ & $\begin{array}{l}\text { Estâncias Jesuíticas. } \\
\text { Bairro histórico. } \\
\text { Rua dos Suspiros. } \\
\text { Casa Nacarello. } \\
\text {. Casa do Vice-rei. } \\
\text {. Arquivo regional. } \\
\text {. Museu do Azulejo. } \\
\text { - Igreja Matriz. } \\
\text {. Praça Maior das Armas. } \\
\text {. Museu Português. } \\
\text { Casa de Lavalleja. } \\
\text { - Museu Municipal. } \\
\text { - Convento de San Xavier } \\
\text { - Praças de Touros. } \\
\text { - Praias do Rio da Prata. } \\
\text { Zonas de pesca e atividade náutica. } \\
\text { Termas. }\end{array}$ & $\begin{array}{l}\text { Excelente. Tem capacidade } \\
\text { para atender os } 500 \text { mil } \\
\text { turistas que recebe } \\
\text { anualmente. }\end{array}$ & $\begin{array}{l}\text { Patrimônio Histórico e } \\
\text { Cultural da } \\
\text { Humanidade. } \\
\text { Dista } 80 \mathrm{Km} \text { de } \\
\text { Buenos Aires e } 1000 \\
\text { Km de Santo Ângelo. }\end{array}$ \\
\hline
\end{tabular}

Figura 38 quadro - roteiro do circuito e suas principais características

Fonte: Adaptado (atualizado) de Nogueira (1999, p. 111-113)

Existe uma proposta de inclusão da Bolívia ao roteiro do Circuito Internacional. Como acontece com a Colônia de Sacramento, esta idéia não irá se efetivar, na prática devido às grandes distâncias entre os atrativos turísticos.

No entanto, a implantação do circuito não satisfez as expectativas da comunidade regional porque as distâncias são grandes entre os centros maiores, tanto da Argentina, como do Brasil, como do Paraguai e Uruguai. A infra-estrutura dos sítios é precária, as estradas estão comprometidas pela falta de manutenção e hotéis e restaurantes não oferecem muitas condições para atender um grande número de visitantes. Há também uma idealização dos recursos potencialmente capazes de contribuir para o incremento do turismo. Na figura 39 estão destacadas as principais 
dificuldades encontradas pelo setor turístico na implantação do circuito e a situação atual.

\begin{tabular}{|c|c|}
\hline DIFICULDADES & SITUAÇÃO HOJE \\
\hline sso aos sítios arqueológicos & O acesso ao mesmo continua igual \\
\hline $\begin{array}{l}\text { Inexistência de empreendimentos de transporte } \\
\text { que realize a visitação regular ao circuito }\end{array}$ & $\begin{array}{l}\text { Existe apenas transporte eventual realizado } \\
\text { pelas agencias de turismo receptivo }\end{array}$ \\
\hline Dificuldades aduaneiras e cambiais; & Não se alteraram \\
\hline $\begin{array}{l}\text { Carência de recursos humanos qualificados nos } \\
\text { diversos setores de atendimento ao turista }\end{array}$ & $\begin{array}{l}\text { Houve melhoria principalmente a partir da } \\
\text { implantação do Rota Missões no Brasil que } \\
\text { oportunizou qualificação em diversão }\end{array}$ \\
\hline $\begin{array}{l}\text { Dificuldade para obtenção de financiamentos } \\
\text { para a realização de novos empreendimentos e } \\
\text { melhoria nos existentes; }\end{array}$ & Continua a mesma \\
\hline $\begin{array}{l}\text { Desconhecimento da história das Missões pela } \\
\text { população local }\end{array}$ & $\begin{array}{l}\text { Melhorou um pouco no BR em atividade Rota } \\
\text { Missões }\end{array}$ \\
\hline $\begin{array}{l}\text { Inexistência de ponte sobre o Rio Uruguai } \\
\text { ligando o Brasil à Argentina junto as cidade de } \\
\text { Porto Xavier- San Javier e Porto Mauá- Alba } \\
\text { Pose }\end{array}$ & A situacão continua a mesma \\
\hline $\begin{array}{l}\text { Distanciamento da região em relação a outros } \\
\text { pontos turísticos }\end{array}$ & $\begin{array}{l}\text { Situação que se agravou, pois na Região } \\
\text { Missões (no BR) que existiam vôos diários para } \\
\text { São Paulo e hoje não há mais esta conexão. }\end{array}$ \\
\hline $\begin{array}{l}\text { Ausência de uma maior diversidade de atrativos } \\
\text { ou opções de lazer }\end{array}$ & $\begin{array}{l}\text { Minimizou após a criação de novos roteiros e } \\
\text { atividades especialmente após a assessoria } \\
\text { prestada através do Projeto Rota Missões. }\end{array}$ \\
\hline $\begin{array}{l}\text { Precariedade de sinalização e postos de } \\
\text { informações }\end{array}$ & $\begin{array}{l}\text { Através do Programa de. SinalizaçãoTurística do } \\
\text { Rota Missões este problema foi minimizado, no } \\
\text { entanto as placas incorretas em relação à } \\
\text { distância entre as cidades.. }\end{array}$ \\
\hline $\begin{array}{l}\text { Falta de entrosamento e trabalho cooperativo } \\
\text { entre as instituições regionais }\end{array}$ & $\begin{array}{l}\text { Minimizou porque as instituições regionaistem } \\
\text { realizado um trabalho mais integrado. }\end{array}$ \\
\hline
\end{tabular}

Figura 39: quadro comparativo situação região 


\title{
Para reverter este quadro Nogueira (1999, p.130-132) traz sugestões que estão
}

\author{
transcritas a seguir:
}

1- A implantação de uma política integrada que venha ao encontro do atendimento das necessidades da população regional, voltada especialmente para a conservação de seu rico patrimônio natural e cultural.

2- A efetiva formatação do produto "CIRCUITO INTERNACIONAL DAS MISSÕES JESUÍTICAS", através:

- de diagnóstico das potencialidades e limitações do turismo regional, evidenciando os recursos reais e os potencialmente capazes de contribuir para o incremento do turismo na região;

- da sensibilização, participação e da qualificação da mão de obra local;

- da diversificação do artesanato com valorização dos temas regionais;

- da melhoria nas condições de capitalização dos empresários locais;

- do resgate da identidade histórico-cultural da região;

- da melhoria dos serviços prestados;

- da articulação dos poderes públicos regionais para a realização de ações conjuntas com o setor privado;

- da implementação de um plano de marketing que valorize os atrativos regionais, mas que não venda uma imagem irreal, para que o turista não se sinta frustrado ao realizar o circuito;

- da intensificação do processo de educação e esclarecimento da população em relação a importância do turismo e do bem receber ao turista;

- da conscientização de muitos comerciantes no sentido da não exploração dos turistas;

- de oferecimento de novos atrativos e novas opções de lazer contemplando especialmente a clientela escolar, responsável, pelo maior fluxo turístico à região, no momento;

- da implantação de projetos que tenham sido discutidos com a comunidade;

- na transformação das potencialidades em produtos diferenciados e competitivos;

- do estabelecimento de linhas regulares de transportes coletivos entre as localidades integrantes do circuito; 
- da melhoria da infra-estrutura básica receptiva tais como serviços de hospedagem, lazer, recreação e de apoio, clãmbio;

- do incentivo a outras modalidades ideais para serem desenvolvidas especialmente no período de baixa temporada, tais como: turismo em propriedades rurais, ecoturismo, turismo de eventos, turismo para a terceira idade.

3- O estabelecimento de políticas estratégicas contemplando ações conjuntas relativas:

- ao desenvolvimento de pesquisas integradas objetivando a análise e produção de novos conhecimentos sobre:

- a oferta e a demanda turística regional;

- a infra-estrutura receptiva;

- a educação patrimonial e educação para o turismo;

- à necessidade de articulação territorial especialmente no que diz respeito aos serviços de transporte, a facilitação de trânsito de turistas, ao sistema de promoção e comercialização do circuito;

- à elaboração de um plano de desenvolvimento turístico identificado com as especificidades regionais, realizado por uma equipe de profissionais capacitados que tenham presente que a atividade turística deverá conciliar crescimento econômico, preservação ambiental, preservação do patrimônio histórico-cultural com as atividades de entretenimento e lazer.

Vê-se que em relação ao tempo em que foi lançado, a importância dada ao produto, via Mercosul, muito pouco foram os avanços ocorridos. Apesar de ter suscitado novos projetos, que serão descritos a seguir, o Circuito Internacional das Missões Jesuítico-Gurani ainda não efetivou-se como "produto turístico das Missões". 


\subsubsection{Projeto integrado de valorização dos sítios arqueológicos missioneiros do Brasil} (1994)

Proposto e implementado pelo Instituto Brasileiro do Patrimônio Cultural (IBPC) em parceria com universidades e comunidade regional. Foi, segundo Vilhena (2006) o primeiro trabalho de cunho interdisciplinar. Foram desenvolvidas atividades no campo da arqueologia, educação patrimonial e reconstituição informatizada. Como objetivos, deste projeto tem-se:

1. Ampliar as atividades de preservação e valorização das Missões, atualmente restrito à São Miguel das Missões, buscando uma maior participação das Universidades e Prefeituras Municipais, para o Desenvolvimento de Ações de Projeto.

2. Atender as demandas das comunidades locais no sentido da valorização de seu patrimônio missioneiro, através de ação afetiva de melhoria das condições de visitação dos sítios, para desenvolver o turismo cultural.

3. Maximizar o potencial de realização, pelo envolvimento amplo das comunidades e instituições engajadas na pesquisa, estudo, preservação e difusão dos remanescentes.

4. Ampliar parcerias para viabilizar a execução de ações e projetos, compartilhando responsabilidades de custos.

5. Coordenar as ações integradas de abordagem aplicadas e critérios de intervenção contemporâneos.

6. Desenvolver as atividades de preservação aplicando métodos científicos, tecnológicos e critérios de intervenção contemporâneos. 
7. Gestionar junto aos setores responsáveis no poder público, pela execução de projetos necessários no campo da infra-estrutura básica de cada local.

8. Buscar a implantação do Programa de Atividades Missões estabelecido pelo IBPC como metas para o biênio 1994-1995.

A operacionalização e as necessidades levantadas por este projeto, estão destacadas no quadro que segue. 


\begin{tabular}{|c|c|c|c|c|}
\hline Ação & São Miguel & São Nicolau & São Lourenço & São João \\
\hline Identificação & $\begin{array}{l}\text { Inventário, registro e } \\
\text { reconhecimento de } \\
\text { estruturas } \\
\text { remanescentes do antigo } \\
\text { povoado, internas e } \\
\text { externas á área cercada; }\end{array}$ & $\begin{array}{l}\text { Inventário, registro e } \\
\text { reconhecimento de } \\
\text { estruturas } \\
\text { remanescentes do antigo } \\
\text { povoado, internas e } \\
\text { externas á área cercada }\end{array}$ & $\begin{array}{l}\text { Inventário, registro e } \\
\text { reconhecimento de } \\
\text { estruturas } \\
\text { remanescentes do antigo } \\
\text { povoado, interno e } \\
\text { externas à área cercada; }\end{array}$ & $\begin{array}{l}\text { Inventário, registro e } \\
\text { reconhecimento de } \\
\text { estruturas } \\
\text { remanescentes do antigo } \\
\text { povoado; }\end{array}$ \\
\hline Proteção & $\begin{array}{l}\text { Conclusão das obras } \\
\text { na Igreja; } \\
\text { Limpeza, } \\
\text { evidenciação } \\
\text { consolidação } \\
\text { emergencial } \\
\text { estruturas das casa dos } \\
\text { índios, colégio, tampo e } \\
\text { cotiguaçú; } \\
\text { Ampliação } \\
\text { bosques de proteção ao } \\
\text { entorno das ruínas; } \\
\text { Infra- } \\
\text { Estrutura:Limpeza } \\
\text { Mecânica - trator } \\
\text { roçadeira; Fiscalização } \\
\text { veículo utilitário; }\end{array}$ & $\begin{array}{l}\text { Remoção de edificação } \\
\text { sobre o sitio } \\
\text { Arqueológico; } \\
\text { Limpeza e conservação } \\
\text { emergencial } \\
\text { estruturas; }\end{array}$ & $\begin{array}{l}\text { Limpeza e Conservação } \\
\text { emergenciais de } \\
\text { estruturas; } \\
\text { Execução de obras de } \\
\text { conservação e infra- } \\
\text { estrutura na portaria; }\end{array}$ & $\begin{array}{l}\text { Cercamento de área; } \\
\text { Limpeza e conservação } \\
\text { emergencial } \\
\text { estruturas } \\
\text { Execução de obras de } \\
\text { conservação e infra- } \\
\text { estrutura na portaria; }\end{array}$ \\
\hline
\end{tabular}




\begin{tabular}{|c|c|c|c|c|}
\hline Valorização & $\begin{array}{l}\text { Implantação do "Projeto } \\
\text { de Informatização do sitio } \\
\text { Arqueológico de São } \\
\text { Miguel das Arcanjo"; } \\
\text { Revitalização de Quinta; } \\
\text { Execução } \\
\text { Arquibancada para o } \\
\text { Som e Luz, em talude } \\
\text { gramado; } \\
\text { Instalação de maquete e } \\
\text { vídeo na Sacristia; } \\
\text { Reformulação } \\
\text { exposição de fragmentos } \\
\text { arquitetônicos } \\
\text { execução de vitrines no } \\
\text { Museu; } \\
\text { Impressão de folhas } \\
\text { didáticas e catálogos do } \\
\text { museu; } \\
\text { Implantação de praça no } \\
\text { entorno da fonte; }\end{array}$ & $\begin{array}{l}\text { Execução e instalação de } \\
\text { equipamento de vídeo } \\
\text { para } \\
\text { patrimonial; } \\
\text { Elaboração e impressão } \\
\text { de folhetaria }\end{array}$ & $\begin{array}{l}\text { Execução e instalação de } \\
\text { placas de sinalização } \\
\text { para acesso e interior do } \\
\text { sítio arqueológico; } \\
\text { Instalação de exposição } \\
\text { permanente na portaria; } \\
\text { Instalação de } \\
\text { equipamentos de vídeo } \\
\text { para educação } \\
\text { patrimonial; } \\
\text { Instalação e impressão } \\
\text { de folhetaria; }\end{array}$ & $\begin{array}{l}\text { Execução e instalação de } \\
\text { placas de sinalização o } \\
\text { acosse e sítio } \\
\text { arqueológico; } \\
\text { Instalação de exposição } \\
\text { permanente na portaria; } \\
\text { Instalação de } \\
\text { equipamentos de vídeo } \\
\text { para educação } \\
\text { patrimonial } \\
\text { Elaboração e impressão } \\
\text { de folhetaria; }\end{array}$ \\
\hline
\end{tabular}

Figura 40: quadro sobre a operacionalização e necessidades regionais. 


\subsubsection{Programa de Capacitação para Conservação, Gestão e Desenvolvimento} Sustentável das Missões Jesuíticas dos Guarani(Argentina, Brasil, Paraguai e Uruguai) (2003-2005).

Criado a partir de uma Oficina Técnica promovida pela Word Monument Fund (WMF), no ano de 2002. A mesma teve como objetivo desenvolver diretrizes uniformes para a conservação do conjunto monumental das Missões Jesuítico-Guarani bem como definir uma estratégia de desenvolvimento comum para o turismo, buscando estabelecer "uma visão global, para as Missões como conjunto e, ao reconhecimento de sua riqueza histórica, artística sociológica, assim como do seu potencial para educação e turismo" (BARABACCl, 2004-5, p. 15)

Durante essa oficina técnica foi realizada uma visitação a dez sítios integrantes dos antigos Trinta Povos. A partir desta visitação foi elaborada uma proposta de trabalho para o período de 2003 a 2005 "baseada na necessidade e oportunidade de promover a cooperação internacional para integrar os esforços e experiências de cada país", a partir da união de instituições e entidades nacionais e internacionais, públicas e privadas sob a coordenação da WMF e da Unesco. Seus objetivos eram: estabelecer mecanismos de cooperação entre os países das Missões; capacitar o pessoal responsável pela conservação, gestão e desenvolvimento das Missões ; identificar e formular projetos de intervenção nas Missões; dar continuidade às ações e estabelecer um quadro de referência comum para a conservação, a gestão e o desenvolvimento do conjunto de seus componentes. 
Os trabalhos desenvolvidos na oficina técnica de 2002

permitiram conhecer a situação e as alternativas de ação no tema das Missões Jesuíticas dos Guarani como um conjunto, mas também como um sistema em diferentes âmbitos temáticos: histórico, geográfico, cultural, patrimonial, turístico, etc. E, a partir daí, desenvolver ações e interações como conseqüência, particularmente a partir da gestão. (BARBACCI e GREMETIERI, 2004-5, p. 27).

Foram feitos questionamentos e levantamento de prioridades em relação ao: estado de conservação do conjunto arquitetônico e sua gestão, arqueologia e desenvolvimento turístico.

O programa de trabalho proposto a partir da oficina técnica divide-se em duas fases sendo a primeira delas com duração de um ano, enfocando a criação de mecanismos de cooperação, a formulação, o projeto do programa e na sua aprovação pelas instituições correspondentes. Como ação desta etapa, foi realizado o Primeiro Curso-Oficina, no ano de 2003 em São Miguel das Missões (Brasil). Este curso-oficina era dirigido a profissionais da Argentina, do Brasil, do Paraguai e do Uruguai com responsabilidade no patrimônio Jesuítico-Guarani. Foi desenvolvido de forma interdisciplinar e participativa, com módulos teóricos e práticos que abrangeram os seguintes temas: documentação e pesquisa; arqueologia; conservação integrada (conceitos, estruturas, materiais); recursos naturais e meio ambiente; uso público 
(turismo, educação, serviços e infra-estrutura); gestão. Teve como principais conclusões e recomendações as destacadas na figura 38.

\begin{tabular}{|c|c|}
\hline SUB-PROJETOS & CONCLUSÕES SE RECOMENDAÇÕES \\
\hline $\begin{array}{l}\text { História e } \\
\text { Documentação }\end{array}$ & $\begin{array}{l}\text { Prioriza uma visão histórica capaz de superar as leituras nacionais. } \\
\text { Integrar com uma leitura histórico Cultural os períodos: guarani, jesuítico, pós-jesuítico e colonial, até } \\
\text { hoje, criando uma consciência da continuidade. } \\
\text { Centralizar a documentação dispersa, em busca de uma informação integrada. } \\
\text { Formar séries documentais que permitam entender o fenômeno missioneiro em seu conjunto e que } \\
\text { aportem informação histórica aos integrantes dos outros subprogramas. }\end{array}$ \\
\hline Arqueologia & $\begin{array}{l}\text { Estabelecer a proteção física dos sítios arqueológicos. } \\
\text { Ampliar a valorização, difusão e a integração social dos sítios arqueológicos. } \\
\text { Executar inventário e diagnóstico do patrimônio o arqueológico missioneiro. } \\
\text { Ampliar o intercâmbio científico. }\end{array}$ \\
\hline $\begin{array}{l}\text { Conservação de } \\
\text { materiais e técnicas } \\
\text { de construção }\end{array}$ & $\begin{array}{l}\text { Estancar a deteriorização de estruturas. } \\
\text { Elaborar glossário e sistema de representação gráfica para diagnósticos padronizados. } \\
\text { Iniciar a realização de diagnóstico. } \\
\text { Estabelecer prioridades. } \\
\text { Implantar canteiros de obras e laboratórios de sítio. } \\
\text { Registrar e descrever os materiais e técnicas utilizadas. } \\
\text { Capacitar pessoal nos sítios. } \\
\text { Ampliar pessoal permanente. } \\
\text { Avaliar ensaios e técnicas de intervenção utilizadas. } \\
\text { Desenvolver estudos comparativos de deteriorização. } \\
\text { Estruturas e Planos de Gerenciamento. Proteger estruturas periféricas. } \\
\text { Proteger bens móveis. } \\
\text { Capacitar e incentivar o ingresso de novos profissionais. }\end{array}$ \\
\hline Uso Público & $\begin{array}{l}\text { Definir conceitos de âmbito global e local. } \\
\text { Estabelecer mensagem comum a transmitir às comunidades e visitantes para conhecer e } \\
\text { compreender a cultura/natureza e propiciar, na educação formal, a idéia de raízes comuns que } \\
\text { fortaleçam a integração regional. } \\
\text { Definir os percursos para visitação dos sítios e o seu conteúdo. } \\
\text { Unificar critérios de apresentação dos sítios para dar idéia de sistema integrado e facilitar a } \\
\text { compreensão dos monumentos. } \\
\text { Sensibilizar as comunidades e visitantes. } \\
\text { Promover a apropriação do processo jesuítico guarani e de suas evidências materiais e imateriais, } \\
\text { enquanto raízes culturais. }\end{array}$ \\
\hline $\begin{array}{l}\text { Paisagem e Meio } \\
\text { Ambiente }\end{array}$ & $\begin{array}{l}\text { Estabelecer Plano de Gestão Ambiental para a Região Jesuítico-Guarani, usando as diretrizes do } \\
\text { Programa MAB Unesco } 2005 . \\
\text { Integrar a área ambiental nos Planos Diretores e de Gerenciamento dos Sítios. }\end{array}$ \\
\hline & Desenvolver planos Diretores de Gerenciamento para os Sítios Arqueológicos Missioneiros. \\
\hline
\end{tabular}


\begin{tabular}{|l|l|} 
Gestão & $\begin{array}{l}\text { Definir atribuições e responsabilidades para o pessoal. } \\
\text { Ampliar recursos Humanos. } \\
\text { Ampliar recursos Financeiros. }\end{array}$ \\
\hline
\end{tabular}

Figura 41:quadro conclusões e recomendações do primeiro curso-oficina - 2003

Fonte: montado a partir de CUSTÓDIO e BRUXEL (2004-5, P. 33-36)

Em relação as questões específicas foram destacados:

\begin{tabular}{|c|l|}
\hline PAís & \multicolumn{1}{c|}{ RECOMENDAÇÕES } \\
\hline Argentina & $\begin{array}{l}\text { Procurar diminuir a temporalidade dos convênios entre as províncias e a Nação, } \\
\text { geralmente afetadas pelas mudanças políticas. } \\
\text { Buscar otimizar o aproveitamento dos centros de Apoio. }\end{array}$ \\
\hline Brasil & $\begin{array}{l}\text { Procurar estender os trabalhos de gestão e conservação tradicionalmente } \\
\text { implementados em São Miguel para outros três sítios arqueológicos. }\end{array}$ \\
\hline Paraguai & $\begin{array}{l}\text { Procurar envolver a área da cultura nas gestões dos sítios arqueológicas. } \\
\text { Solucionar à Unesco a inserção de Trinidad e Jesus na mesma declaração do } \\
\text { Conjunto Jesuítico Guarani da Argentina e Brasil. }\end{array}$ \\
\hline Uruguai & $\begin{array}{l}\text { Buscar ajustar o relacionamento entre a comissão do Patrimônio Cultural da Nação } \\
\text { e a Comissão Honorária de Colônia do Sacramento para uma melhor gestão da } \\
\text { Calera de lãs Huerfanas. }\end{array}$ \\
\hline
\end{tabular}

Figura 42: quadro sobre as necessidades específicas.

Fonte: montado a partir de CUSTÓDIO e BRUXEL (2004-5, P. 37-38)

Estes temas abordados no Primeiro Curso-Oficina foram transformados em subprogramas que serão desenvolvidos de forma sistemática e detalhada, tanto no âmbito do conjunto como de cada sítio, na segunda etapa do programa, prevista para o período de 2003-05.Durante o ano de 2004 foram realizadas ações significativas, como resultado deste projeto, como podem ser observadas no quadro que segue: 


\begin{tabular}{|l|l|}
\hline \multicolumn{1}{|c|}{ PAÍS } & \multicolumn{1}{|c|}{ AÇÕES REALIZADAS } \\
\hline ARGENTINA & $\begin{array}{l}\text { Restauração do portal lateral de San Ignácio Mini. Projeto para os centros de } \\
\text { interpretação das Missões. }\end{array}$ \\
\hline BRASIL & $\begin{array}{l}\text { Estabilização dos muros e pisos em São Lourenço e São João Batista envolvendo } \\
\text { escavações arqueológicas e investigação histórica. } \\
\text { Desenvolvimento do projeto Centro de Documentação e Investigação de São Miguel. } \\
\text { Desenvolvimento do projeto de consolidação do Sobrado Silva em São Nicolau. } \\
\text { Conclusão do projeto de sinalização interpretativa em São Miguel. }\end{array}$ \\
\hline PARAGUAl & Início dos trabalhos para o desenvolvimento dos planos de Trinidad e Jesus. \\
\hline
\end{tabular}

Figura 43: quadro das ações desenvolvidas em 2004

Fonte: montado a partir de CUSTÓDIO (2005, p. 10)

O Segundo Curso-oficina foi realizado na cidade de Posadas no período de 21 a

27 de novembro de 2004. Como resultado do mesmo tem-se as recomendações destacadas no quadro que segue 


\begin{tabular}{|c|c|}
\hline SUB-PROJETOS & CONCLUSÕES SE RECOMENDAÇÕES \\
\hline $\begin{array}{l}\text { História e } \\
\text { Documentação }\end{array}$ & $\begin{array}{l}\text { Empreenderuma visão.histórica capaz de superar as leituras nacionais; } \\
\text { Integrar as leituras histórico-culturais aos períodos:guarani, jesuítico, pós-jesuítico e da colonização } \\
\text { até hoje criando uma consciência de continuidade;centralizar a documentação dispersa até uma } \\
\text { informação integrada; formar séries documentais que permitam entender o fenômeno em conjunto e } \\
\text { que aportem informações históricas aos integrantes dos sub-programas. }\end{array}$ \\
\hline $\begin{array}{l}\text { Conservação de } \\
\text { materiais e técnicas } \\
\text { de construção }\end{array}$ & $\begin{array}{l}\text { Frear o deterioramento das estruturas; elaborar léxico e sistema de representação e mapeamento } \\
\text { comum; elaborar glossário técnico espanhol-portugues; iniciar a elaboração de diagnósticos; } \\
\text { determinar as prioridades; capacitar o pessoal permanente dos sítios; incrementar o pessoal } \\
\text { permanente; continuar o plano de manejo e proteção de estruturas periféricas; proteger os bens } \\
\text { móveis, entre outras. }\end{array}$ \\
\hline $\begin{array}{l}\text { Paisagem e Meio } \\
\text { Ambiente }\end{array}$ & $\begin{array}{l}\text { Integrar o componente natural a proteção com similar nível do monumento; vincular as comunidades } \\
\text { aos sítios, valorizando as manifestações culturais (patrimônio intangível); promover a capacitação e } \\
\text { entretenimento dos guaranis para atuar na preservação natural e cultural nos sítios como intérpretes.; } \\
\text { proteger a paisagem urbana e definir normas que evitem a perda da identidade dos povos (patrimônio } \\
\text { jesuítico e ambiental intangível); continuar com a incorporação do componente ambiental na } \\
\text { planificação da gestão dos sítios; desenvolver um estudo comparativo da legislação de conservação } \\
\text { de patrimônio natural e cultural identificando lacuna normativos como base de uma gestão comum }\end{array}$ \\
\hline Gestão & $\begin{array}{l}\text { Estruturar planos diretores de manejo para os sítios arqueológicos missioneiros; definir atribuições e } \\
\text { responsabilidades e ampliar e capacitar recursos humanos; ampliar os investimentos em recursos } \\
\text { econômicos; incorporar o povo guarani na gestão do patrimônio jesuítico-guarani de acordo com suas } \\
\text { expectativas. }\end{array}$ \\
\hline
\end{tabular}

Figura 44: quadro das conclusões e recomendações do segundo curso-oficina - 2004

Fonte: montado a partir de CUSTÓDIO (2005, p. 18-24)

Com a realização do Terceiro Curso Oficina no período de 24 a 30 de outubro de 2005 em Itapua, no Paraguai, foi encerrado este programa que teve como grande resultado a unificação das técnicas de conservação e consolidação dos sítios, a apreensão de metodologias de trabalho interdisciplinar e como mais inovador, a introdução da variável ambiental nos trabalhos relativos aos sítios arqueológicos das missões. 


\subsubsection{Caminho das Missões (Brasil)}

Com objetivos semelhantes aos do Circuito Internacional a 16 de agosto de 2001 foi lançado o "Caminho das Missões", que funcionou em caráter experimental até março de 2002. Seu projeto inicial, de acordo com seus idealizadores, foi inspirado no "Caminho de Santiago de Compostela" e incluía, inicialmente, um percurso de 170 quilômetros abrangendo seis dos antigos Sete Povos da Região Missioneira Brasileira (São Nicolau, São Luiz Gonzaga e seu distrito São Lourenço Mártir, São Miguel das Missões, Santo Ângelo e São João Batista, no Município de Entre-ljuís). Hoje o caminho estende-se até o município de São Borja, tendo sua quilometragem aumentada em $325 \mathrm{Km}$ e passando pelos antigos Sete Povos das Missões.(NOGUEIRA, 2004)

O percurso do Caminho das Missões segue as antigas trilhas guarani, buscando seguir o mais próximo do caminho original que ligava as reduções jesuíticas, hoje relativamente modificadas pela ação do homem. Após passar pelos caminhos missioneiros vai pelas velhas estradas dos tropeiros, seguindo por pontos de interesse que servem como referências históricas, como casas centenárias, moinhos missioneiros, pedreira missioneira (local de onde eram retiradas as pedras para a construção da Igreja de São Miguel).

Este caminho, segundo seus organizadores, apresenta-se como uma jornada que pode contemplar diferentes interesses: peregrinação mística, conhecimento da 
cultura e da tradição regional, lazer, autoconhecimento, superação pessoal ou esporte. Seu projeto contempla a ampliação do percurso até as Missões Argentinas, na Província de Misiones, e Missões Paraguaias em Itapua, criando no Cone Sul, segundo seus produtores e comercializadores, um roteiro tão significativo quanto o Caminho de Santiago de Compostela, percorrido todos os anos por milhares de peregrinos de todo o mundo. Está iniciando também uma proposta para que o caminho seja percorrido por ciclistas.

A princípio estavam disponíveis aos caminhantes três opções de trajeto, diferenciados em função das distâncias a serem percorridas e do tempo de duração da jornada, conforme pode ser visto na figura 45. Todos tendo como destino final o Município de Santo Ângelo, podendo partir de São Nicolau (170 km em sete dias); São Luiz Gonzaga (130 Km em 5 dias) ou São Miguel das Missões (74 km em 3 dias). Atualmente foi disponibilizada uma nova opção com saída de São Borja para Santo Ângelo (325 Km, 14 dias) e São Borja a São Nicolau, ou vice-versa (155 Km, 7 dias). 


\begin{tabular}{|c|c|c|}
\hline DIAS & & PERCURSO A SER PERCORRIDO E PRINCIPAL ATRATIVO \\
\hline $1^{\circ}$ & & $\begin{array}{l}\text { City Tour em São Borja: Museu Getúlio Vargas, Museu Municipal, Casa João Goulart, } \\
\text { Museu de Estância e Sede dos Angueras, Alameda dos Presidentes, Altar Missioneiro, } \\
\text { Praça XV de Novembro. }\end{array}$ \\
\hline $2^{\circ}$ & & $\begin{array}{l}\text { Deslocamento de Passo da Barca até Sarandi }(20 \mathrm{~km}) \text {. Possibilidade de Banho no Rio } \\
\text { Uruguai, jogo de bocha e lavagem de roupa. }\end{array}$ \\
\hline $3^{\circ}$ & & $\begin{array}{l}\text { Deslocamento da Fazenda São Pedro }(15 \mathrm{~km}) \text { - contato com as lidas cotidianas de uma } \\
\text { fazenda. Possibilidade de Banho no Rio Uruguai. }\end{array}$ \\
\hline $4^{\circ}$ & & $\begin{array}{l}\text { Deslocamento da Fazenda São Pedro e Sambara }(20 \mathrm{~km}) \text {. Possibilidade de banho de } \\
\text { Cachoeira. Contato com as lidas cotidianas de uma pequena propriedade rural baseada na } \\
\text { agricultura familiar. }\end{array}$ \\
\hline $5^{\circ}$ & & $\begin{array}{l}\text { Deslocamento de Sambara a São José Velho a Fazenda (27 km) - Apresentação de } \\
\text { danças Gauchescas. }\end{array}$ \\
\hline $6^{\circ}$ & & $\begin{array}{l}\text { Deslocamento São José Velho a Fazenda }(29 \mathrm{~km}) \text { - observações de fazendas de criação } \\
\text { de gado. Passeio de barco pelo Rio Uruguai. }\end{array}$ \\
\hline $7^{\circ}$ & & $\begin{array}{l}\text { Deslocamento da Fazenda a São Nicolau }(27 \mathrm{~km}) \text { - Passagem do Rio Piratini de Balsas, } \\
\text { Sítio Arqueólogo de São Nicolau, Casarão dos Silva, apresentações de música gaúchas. }\end{array}$ \\
\hline $8^{\circ}$ & * & Deslocamento de São Nicolau a Rincão dos Teixeiras (31km) \\
\hline $9^{\circ}$ & * & $\begin{array}{l}\text { Deslocamento do Rincão dos Teixeiras a São Luiz Gonzaga (17km). Visitação aos pontos } \\
\text { turísticos da cidade (Catedral que abriga } 12 \text { peças da estátua missioneira, a praça, os } \\
\text { museus e a gruta Nossa Senhora de Lurdes.) }\end{array}$ \\
\hline $10^{\circ}$ & * & $\begin{array}{l}\text { Deslocamento de São Luiz Gonzaga a São Lourenço }(27 \text { km) - visita ao sítio Arqueológico } \\
\text { de São Lourenço Mártir, apresentação de música Missioneira. }\end{array}$ \\
\hline $11^{\circ}$ & * & $\begin{array}{l}\text { Deslocamento de São Lourenço a São Miguel das Missões (23 km). Visita ao Sítio } \\
\text { Arqueológico de São Miguel Arcanjo e Museu das Missões, Espetáculo Som e Luz. }\end{array}$ \\
\hline $12^{\circ}$ & * & $\begin{array}{l}\text { Deslocamento de São Miguel das Missões a Carajazinho }(32 \mathrm{~km}) \text { - visita aos locais de onde } \\
\text { foram retiradas as pedras para a construção da Redução do São Miguel Arcanjo. } \\
\text { Declamações Gauchescas. }\end{array}$ \\
\hline $13^{\circ}$ & * & $\begin{array}{l}\text { Deslocamento de Carajazinho ao Parque das Fontes }(27 \mathrm{~km}) \text { - visita ao Sítio Arqueológica } \\
\text { de São João Batista. Parque das fontes com possibilidade de passeio e banho de piscina. } \\
\text { Show musical e conhecimento da História das missões. }\end{array}$ \\
\hline $14^{0 * *}$ & & $\begin{array}{l}\text { Parque das Fontes a Santo Ângelo }(14,5 \mathrm{~km}) \text {. Travessia do Rio ljuí de Balsa. Chegada à } \\
\text { Catedral Angelopolitana. }\end{array}$ \\
\hline
\end{tabular}

Figura 45: quadro do roteiro do caminho das missõesSão Borja - Santo Ângelo

Fonte:........

*percurso de sete dias $\quad$ ** percurso de três dias 


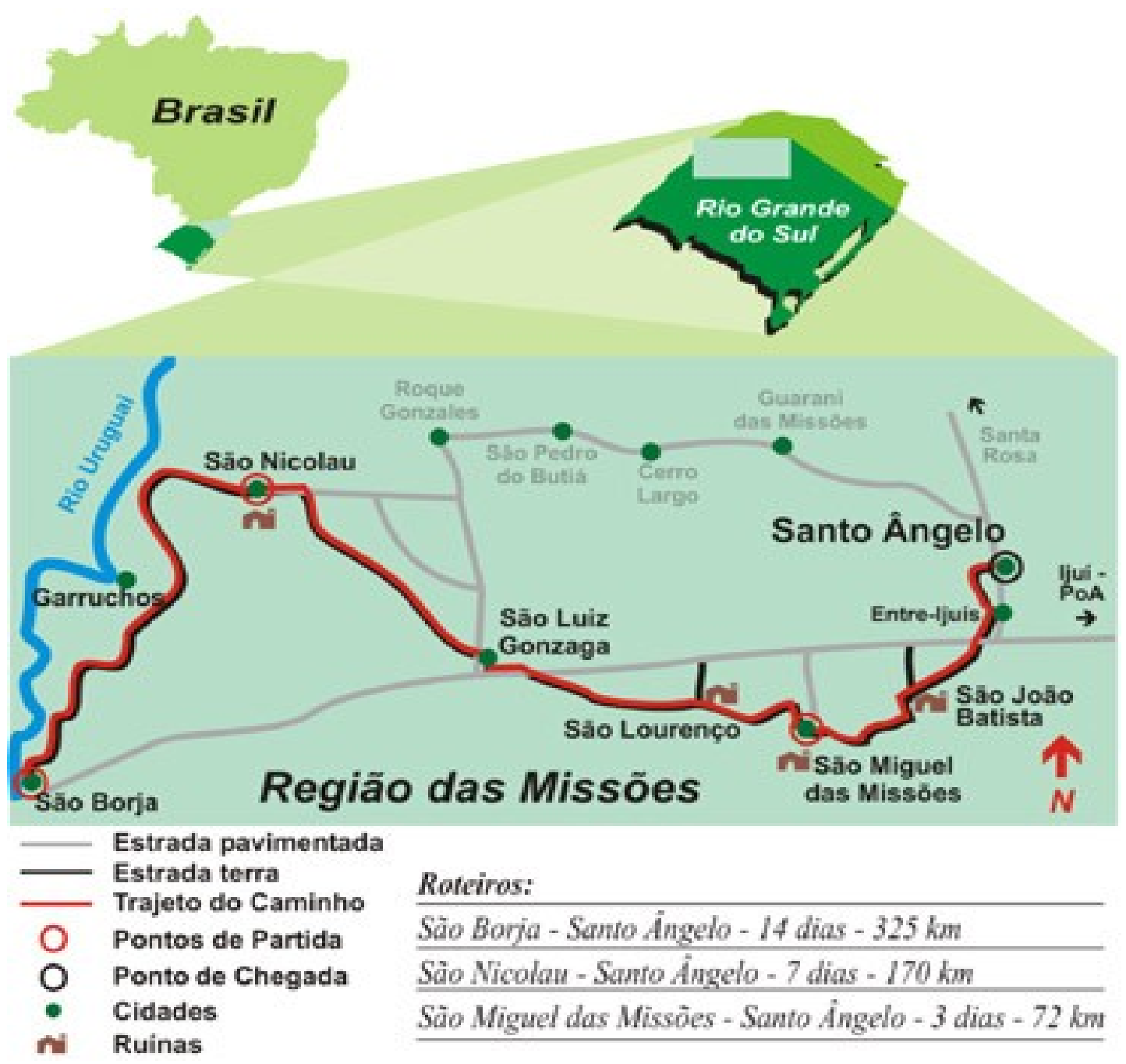

Figura 46: mapa do CAMINHO DAS MISSÕES

Fonte: www.caminhodasmissões.com.br 
Observa-se que, apesar de ter sido lançado há quatro anos e, estar em efetivo funcionamento, tendo recebido em torno de 500 turistas oriundos principalmente das cidades de São Paulo, Porto Alegre e Brasília, o Caminho das Missões prescindiu de um planejamento integrado com os diversos setores da comunidade regional, constituindo-se em uma proposta um tanto isolada e que enfrenta problemas principalmente em relação à infra-estrutura de atendimento ao peregrino, especialmente no que diz respeito à hospedagem. Este problema é difícil de ser solucionado porque os empreendimentos prestadores de serviço não possuem condições financeiras para investir sem a certeza de um aumento no fluxo de peregrinos a serem atendidos.

\subsubsection{Rota Missôes (Brasil)}

O Projeto Rota Missões teve como precursor o projeto "Setorial de Turismo" no ano de 2002 que, sob responsabilidade do Serviço de Apoio às Micro e Pequenas Empresas no Rio Grande do Sul (Sebrae/RS). Envolveu os Conselhos Municipais de Turismo, os monitores formados pelo Programa Nacional de Municipalização do Turismo e quarenta empreendedores da Região das Missões, no Brasil. Através deste projeto foram oferecidos cursos de capacitação nos diferentes municípios dos empreendimentos integrantes do Setorial do Turismo. 
Em maio de 2003 foi lançada a "Rota Missões", cujo o objetivo era de consolidala como eixo de integração da Região das Missões (brasileira) nos setores do turismo, do artesanato e do agronegócio, através do fomento dos sistemas produtivos locais.

Conforme o Sebrae/RS (2006), através da realização do Projeto de Desenvolvimento da Rota Missões, será possível trazer novas oportunidades para a região interligando os setores de turismo, agronegócios e artesanato, numa proposta única de desenvolvimento, já que a matriz produtiva predominante, a agropecuária, precisa ser reestruturada visto que não mais atende as necessidades das comunidade regional. É possível criar novas alternativas para a região focando em seu patrimônio cultural e histórico, através de uma atuação junto ao setor de turismo, agregando valor ao agronegócio e ao artesanato.

No segmento do turismo o projeto foi dirigido a empreendedores das áreas de lazer (campings, balneários, parques municipais, pesque-pague, propriedades rurais); no ramo de hospedagem (hotéis e pousadas); na alimentação (restaurantes, pizzarias, bares, lancherias, sorveterias, cafés e confeitarias); e entidades de classe como associação de taxistas e guias de turismo, tendo como público alvo a população local. Os focos de trabalho foram os atrativos turísticos, hospedagem e alimentação e o "espírito missioneiro".

Foi dado ênfase ao conhecimento e valorização da História das Missões tanto do Primeiro como Segundo Ciclo Missioneiro. Assim foram envolvidos sítios arqueológicos, 
museus, eventos relacionados com Missões, passeios a cavalo, propriedades rurais com significados para a história, caminhadas histórico-culturais, trilhas ecológicas, grupos de dança, música, teatro ou contadores de história tendo como público alvo a população regional, nacional e internacional.

Quanto ao "Espírito Missioneiro", foi oferecido à comunidade, os empreendedores e as escolas de Ensino Fundamental e Médio, palestras sobre a História das Missões. Foi criada a "Marca Missioneira" a partir de Estudos de Campanha de divulgação, sinalização turística e produção de material de divulgação integrado.

No segmento artesanal foram envolvidos artesãos, Associações e Cooperativas de Artesãos, Empreendedores do Setorial de Turismo e locais de venda de artesanato na região. O trabalho desenvolvido envolveu diagnósticos e mobilização, capacitação técnica gerencial, oferecimento de oficinas e prestações de consultoria divulgação e comercialização.

O setor de agronegócio teve como objetivo geral à qualificação e diferenciação do agronegócio local com aproveitamento das potencialidades produtivas e culturais, para um público alvo integrado por fornecedores de alimentos (agroindústrias familiares e empresariais, escolas agrícolas e produtores rurais) e fornecedores de refeições (pousadas, restaurantes, hotéis e bares). Para sua efetivação foram realizados diagnósticos e mobilização, capacitação técnica e gerencial, sendo desenvolvidas 
atividades referentes a legislação nas empresas, processos de certificação, participação em eventos e feiras, comercialização.

Em sua primeira etapa, até o final de 2005, o Projeto Rota Missões atingiu 24 municípios e atendeu mais de uma centena de empreendimentos. Para tanto efetivou parcerias com as seguintes instituições: Centro de Vivências Integradas de São Francisco de Assis - Companhia de Jesus - Colégio Anchieta (POA). Emater/RS, Instituto Nacional de Seguridade Social (INSS). Instituto do Patrimônio Histórico Artístico Nacional, Ministério da Agricultura, Ministério do Turismo, Ministério da Integração, Ministério da Segurança Alimentar, Secretaria Estadual do Turismo, Serviço Nacional de Aprendizagem Rural (Senar), Universidade do Estado do Rio Grande do Sul (UERGS), Universidade Regional Integral do Alto Uruguai e das Missões (URI). Como principais resultados obtidos na primeira etapa deste projeto o Sebrae/RS (2006) destaca:

a) a geração de novos negócios: lançamento da cavalgada Guaranítica, lançamento da Cavalga do Rolador;o lançamento do CD da aldeia indígena do Inhacapetum - Terra Kõeju, lançamento da trilha dos Santos Mártires.

b) o aproveitamento das potencialidades: identidade gastronômica; Projeto Circuito $\mathrm{Da}$ Imaginária Missioneira (envolvendo cinco municípios); Projeto do Cerro do Inhacurutum (envolvendo sete famílias empreendedoras); organização de Calendário Regional de Festas Missioneiras; foram listados 61 eventos). 
c) melhoria dos produtos: foram disponibilizadas aos empreendedores cadastrados no projeto, 55 consultorias especializadas; foram ministradas cinco oficinas regionais de Artesanato "O Olhar e a Tendência" das quais participaram 197 artesãos e 28 oficinas de melhoria de produtos alimentícios; foi promovida a padronização do Sistema de Inspeção Municipal (SIM); foram criadas logomarcas para a Pousada dos Jesuítas, em São Nicolau, Hotel Farol em Porto Xavier, Ivo's Hotel em São Luiz Gonzaga, Hotel Pedras Brancas no município de Caibaté.

d) projeto Gráfico das Missões: criação de produtos promocionais da Rota Missões: bonés, canecas, camisetas, embalagens para artesanato(sacolas, etiquetas, “envelopes").

e) inovação de hotelaria: foi criado um kit com produtos artesanais padronizado que será disponibilizado em todos os hotéis da região (coleção para a Hotelaria Missioneira).

f) melhoria dos Serviços: 72 capacitações e cinco visitas técnicas; projeto $s$ de sinalização rodoviária (seis painéis, seis pórticos e 366 placas de sinalização); implantação de postos de informação turísticas em dez municípios;

g) trabalho integrado e cooperado: organização dos segmentos regionais através do oferecimento de 25 oficinas de planejamento, implantação das cidades das tortas, integração entre hotelaria e artesãos da região..

h) criação de redes de comercialização; Projetos da Central de Negócios do Artesanato, Formação de Sistemas de Compra conjunta de Hotelaria; 11 hotéis; Integração de 
operantes de turismo: 5 agências receptivas locais, 7 operadoras do Estado, Parceria do Projeto das Casas de Produtos Missioneiros.

i) divulgação da Rota Missões: criação de materiais institucionais; participação em eventos de turismo de âmbito regional, nacional e internacional e divulgação regional através dos meios de comunicação locais e reginais.

Em 2006 inicia-se uma nova etapa do Projeto Rota Missões com objetivo de consolidar o destino turístico Rota Missões como forma de promover o desenvolvimento sustentável na região Missioneira. Sua meta é aumentar em 15\% a ocupação hoteleira em 3 anos, ampliar o fluxo turístico na Rota Missões em 15\% em 3 anos e aumentar o faturamento dos empreendimentos envolvidos em 3 anos.

O mercado ao qual dirige-se o projeto, na fase atual, atual está dividido em:

- Mercado Local - Municípios da Rota Missões (com o acréscimo do Município de São Borja) dando ênfase às festas missioneiras, áreas de lazer e gastronomia. Sua divulgação se dará na imprensa local, no festival cidade das tortas, no degusta missões e nos estandes regionais.

- Mercado Regional - RS, PR (Foz do Iguaçu), Província de Misiones na Argentina e Departamento de Itapua no Paraguai, no qual será trabalhado a História das Missões e suas festas missioneiras. A divulgação será dada através dos materiais do portal da Rota Missões, mapa ilustrado, guia das missões nas escolas, roadshows e estandes em eventos regionais. 
- Mercado Nacional e Internacional: SP, PR, RJ, DF, MS, MG, SP, Argentina, Uruguai, Europa (Alemanha, França, Espanha, Itália) e Japão. Para este mercado qual será incentivado e investido na aventura, cultura e ecoturismo. Para sua dinamização será elaborado um projeto promocional e a divulgação será feita através de encontro de negócios, eventos do trade e produção de material de divulgação nos idiomas espanhol e inglês.

Apesar do grande investimento feito, na região, através deste projeto os resultados, em curto prazo, não foram tão evidentes. Dentre os resultados obtidos temse a identidade visual da "Rota Missões", a qualificação do artesanato regional a sinalização turística e ampliação da discussão sobre a importância da história e da cultura regional.

\subsubsection{Rede Regional de Conhecimento do "Circuito Internacional das Missões Jesuíticas" (Argentina, Brasil, Paraguai e Uruguai)}

Instaurada no ano de 2004 com a assinatura do convênio de cooperação entre instituições de ensino superior da Argentina (Universidade Nacional de Misiones-Unam, Universidade do Nordeste-UNNE, Instituto Ruiz de Montoya e o Instituto Universitário Gaston Dachary); do Paraguai (Universidade Nossa Senhora da Assunção) e do Brasil 
(Universidade Regional Integrada do Alto Uruguai e das Missões-URI e Universidade União das Américas).

Essa rede teve como objeto estabelecer as bases e os critérios sobre os quais as universidades e os institutos participantes, realizarão ações conjuntas de colaboração acadêmica, científica e cultural para o enriquecimento das funções educativas, de pesquisa e extensão que realizam sobre a temática Jesuítico-Guarani são destinadas a transferir o conhecimento gerado e a ser gerado dos setores privado ou público, articulando com os governos, na promoção do desenvolvimento da região. A partir deste convênio foi constituída a "Rede Regional do Conhecimento do Circuito Internacional das Missões Jesuíticas" com o objetivo de contribuir para a geração de novas condições que possibilitem o desenvolvimento sustentável do Circuito Internacional das Missões Jesuíticas tendo como eixo central o turismo.

Com a assinatura do convênio, as instituições signatárias do mesmo se comprometem a realizar as ações que seguem:

a) Consolidar a rede das instituições de ensino superior da região desenvolvendo um plano estratégico na temática Jesuítico-Guarani e seu posicionamento no contexto internacional.

b) Constituir um fórum permanente de consulta e coordenação sobre a temática Jesuítico-Guarani. 
c) Proporcionar o estudo de caso nas localidades onde se encontram os assentamentos Jesuítico-Guaranis, desde a transversalidade curricular até a abordagem interdisciplinar.

d) Contar com a participação das diferentes disciplinas científicas do fórum permanente, em cada um dos eventos científicos que serão desenvolvidos sobre a temática Jesuítico-Guarani.

e) Favorecer o intercâmbio de recursos humanos entre os membros da rede e propiciar a formação de novos recursos humanos na região.

f) Gerar pautas consensuadas para a conservação, restauração e manutenção do recurso turístico cultural Jesuítico-Guarani.

g) Sistematizar a divulgação interna e externa da importância que tem o meio acadêmico como parte estratégica na abordagem e articulação do conhecimento vinculado ao Circuito Internacional das Missões Jesuíticas.

No ano de 2004 foram realizadas oito oficinas nas quais foram definidas as diretrizes gerais do projeto e os objetivos para a elaboração de um plano estratégico destinado às localidades que integram o Circuito Internacional das Missões Jesuíticas. Os objetivos elencados foram: realizar um diagnóstico sobre os estado de cada um dos conjuntos Jesuíticos dos três países; gerar pautas para a valorização, conservação, restauração, manutenção e exploração sustentável do recurso turístico-cultural jesuítico-guarani na região; realizar um mapeamento dos atrativos turísticos complementares ou alternativos existentes para articulador com o patrimônio histórico 
cultural; favorecer o intercâmbio de recursos humanos entre as universidades que integram o projeto, proporcionar o estudo de casos e a pesquisa científica interdisciplinar; incluir os conteúdos do Circuito Internacional das Missões Jesuíticas e do patrimônio nos diferentes níveis curriculares do sistema educativo dos países que integram o projeto; promover um maior acesso da comunidade local e regional para que possam desfrutar das atividades de lazer e suas inter-relações com a natureza e a cultura; gerir o financiamento para sustentar as pesquisas e estudos necessários; detectar fontes de financiamento regional, provincial, nacional e internacional para sustentar os estudos e pesquisas que forem realizados e necessárias para a adequação de atrativos e infra-estrutura; sistematizar a difusão interna e externa do Circuito Internacional das Missões Jesuíticas; fomentar o início e o crescimento de empreendimento turísticos no Circuito Internacional das Missões Jesuíticas; incentivar a instalação de micro empreendimento produtivo no campo das artes, artesanatos, gastronomia, serviços e outros.

Realizaram-se também: reuniões com as comunidades locais; participação em feiras regionais, nacionais e internacionais, além do levantamento da demanda regional, não listados aqui pela sua extrema similaridade com as questões levantadas pelos projetos já comentados anteriormente. $O$ fato de que nas universidades participantes deste trabalhos, os representantes não serem sempre os mesmos e em alguns casos não serem pessoas ligadas à área, este projeto não tem apresentado resultados efetivos. 


\subsubsection{Programa de Cooperação Técnica Para Roteirização Iguaçu - Missões}

Este programa realizado a partir de uma parceria entre o Ministério do Turismo e o Sebrae Nacional tem por objetivo a formação de agentes para acompanhamento, estruturação e avaliação do processo de roteirização no Brasil como parte integrante do programa de Regionalização do Turismo - Roteiros do Brasil.

A roteirização é o processo de unir, a partir de um planejamento integrado, em um mesmo itinerário, atrativos, equipamentos e serviços turísticos de uma ou mais região turística, de forma a agregá-los e consolidá-los em um produto de turismo, que será comercializado no mercado. Constitui-se numa estratégia fundamental para atingir a diversificação da oferta que é um dos objetivos do Programa de Regionalização do Turismo. Sua efetivação se dará pela inserção de produtos diferenciados nos mercados nacional e internacional. Desse modo, pode-se entendê-la como o processo de estruturar a oferta de uma região, em um produto comercialmente viável.

Foram definidos roteiros em cada uma das microrregiões brasileiras; no norte o roteiro do Vale do Acre; no nordeste o roteiro integrado Ceará, Piauí e Maranhão; no centro-oeste o roteiro Brasília-Chapada dos Veadeiros; no sudoeste o roteiro da Estrada Real e na macrorregião Sul do Brasil foi escolhido o Roteiro das Missões, reunindo os municípios paranaenses de Foz do Iguaçu e Guairá e os municípios da Região das Missões do Rio Grande do Sul (Caibaté, Entre-ljuís, Porto Xavier e São Nicolau), numa parceria entre as secretarias e os Conselhos Municipais de Turismo, a Setur e o Sebrae. 
Destaca-se ainda neste roteiro a integração com o circuito Internacional das Missões, envolvendo os Sítios de San Ignácio e Sant'Ana Loreto na Argentina, Encarnacion, Trinidad e Jesus no Paraguai, São Miguel, São Nicoulau, São João e São Lourenço no Brasil, num percurso aproximadamente de $350 \mathrm{Km}$, oferecendo história, cultura e natureza.

A roteirização é promovida pelo Arranjo Produtivo Local ${ }^{29}$ (APL) de Turismo Rota Missões e definirá as opções de passeio, trilhas e visitas a monumentos históricos, entre outras atividades que serão oferecidas aos turistas nos municípios que integram a Rota Missões bem como do Circuito Internacional das Missões Jesuíticas. Estas ações por objetivo um aumento projetado em $5 \%$ na taxa de ocupação dos hotéis, a formação de uma central hoteleira e a abertura de seis postos de informação na região. Além dessas atividades, também estão previstas a formação de rotas gastronômicas e a legalização de associação de artesãos e de agroindústrias da área, para atender a demanda de turistas.

Assim, a proposta de Roteirização Turística, no âmbito do Programa de Regionalização do Turismo do Ministério do Turismo, tem como objetivo consolidar o Roteiro Iguassu-Misiones através da construção de parcerias, promoção da integração e compromisso dos envolvidos, adensamento dos negócios na região, inclusão social,

29 Os APLs são aglomerações de empresas localizadas em uma mesma região, que apresentam especializações produtivas e mantêm vínculos de articulação, interação, cooperação e aprendizagem entre elas e com outros agentes locais, como governos, associações empresariais e instituições de crédito, ensino e pesquisa. (Sebrae/RS, 2006) 
resgate e preservação dos valores culturais e ambientais e o aumento de investimentos e serviços ofertados na região.

A criação e consolidação de novos roteiros turísticos e o aumento de investimentos nos já existentes, com vistas à qualificação dos serviços, possibilita o aumento do fluxo de turistas, propiciando sua maior permanência na região turística e, conseqüentemente, maior ingresso e circulação de capital.

Como parceiros deste projeto tem-se os governos locais e regionais do Brasil, da Argentina e do Paraguai, secretarias de Turismo dos Estados do Paraná e Rio Grande do Sul e representantes regionais do Sebrae e Senac. Houve a incorporação efetiva da Fundação dos Municípios das Missões, da Prefeitura Municipal de Foz do Iguaçu através da Secretaria de Turismo, do Consórcio dos Municípios Lindeiros ao Lago de Itaipu, da Câmara de Turismo de Misiones da Argentina e da Secretaría Nacional de Turismo do Paraguai. Juntas estas entidades "pretendem construir o caminho da integração, com o apoio dos governos brasileiro, argentino e paraguaio".

A região de abrangência deste projeto é integrada pelas localidades abaixo listadas e pode ser observada na figura 47.

Na Argentina: a Provincia de Misiones (Posadas, Santa Ana, San Ignacio, Loreto, San Javier, Santa Maria, Wanda e Puerto Iguazu) e a Provincia de Corrientes (Santo Tomé) 
No Brasil: o estado do Paraná (Foz do Iguaçu, Guairá e Itapulância) e o estado do Rio Grande do Sul (Caibaté, Entre-ljuís, Porto Xavier, Roque Gonzáles, Santo Ângelo, São Borja, São Luiz Gonzaga, São Miguel das Missões e São Nicolau).

No paraguay: o Departamento de Itapúa (Encarnacion,Trinidad del Paraná, Jesus de Taravengüe e San Cosme y Damian), o Departamento de Misiones (San Ignacio de las Misiones, Santa Maria de Fe e Santiago de las Misiones) e o Departamento Alto Paraná (Ciudad Del Este, Hernandarias e Presidente Franco). 


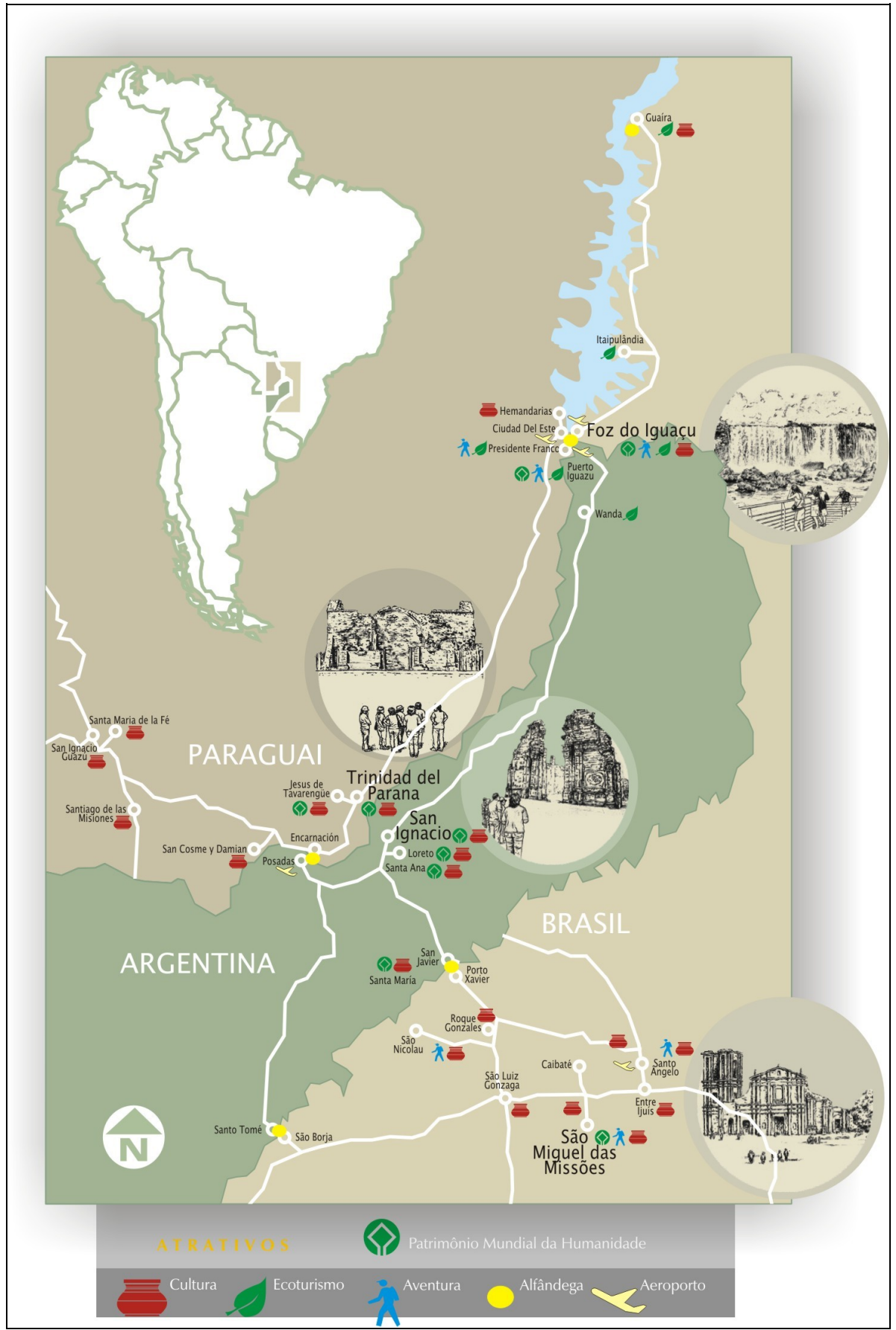

Figura 47: mapa da área de abrangência do projeto de roteirizaçãoiguaçu-missões Fonte: relatório SEBRAE, 2005 
Dentre as ações já realizadas destacam-se: reunião com as lideranças da comunidade regional em São Miguel das Missões, Brasil, em novembro de 2005. Assinatura do Termo de Cooperação lançamento no Salão Brasileiro de Turismo realizado em São Paulo, em outubro de 2006, Participação no Salão Gaúcho de Turismo (POA). Lançamento na Argentina (11/7/06) e Lançamento no Paraguai (27/7/06). Como ações previstas para o período (2006-2007) têm-se: visitas técnicas para operadores internacionais;fam-tour para agências de viagens do mercado nacional; fam-press para imprensa nacional; criação de materiais de divulgação; participação em eventos nacionais e internacionais; realização de roadshow pela América do Sul e Europa. As ações as quais foram dadas maior dinamismo foram os trabalhos de divulgação em feiras nacionais e internacionais de turismo e reuniões.......

As Cataratas do Iguaçu são um dos mais importantes atrativos turísticos da Argentina e do Brasil tanto para o mercado nacional como o internacional, oferecendo de forma conjunta uma grande diversidade de opções relacionadas à aventura, ao ecoturismo e à cultura como pode ser observado no quadro que segue. 


\begin{tabular}{|c|c|c|c|}
\hline ATRATIVO & ARGENTINA & BRASIL & PARAGUAI \\
\hline $\begin{array}{l}\text { Patrimônio da } \\
\text { Humanidade }\end{array}$ & $\begin{array}{l}\text { Parque Nacional de } \\
\text { Iguaçu. } \\
\text { Sítios Arqueológicos de } \\
\text { San Ignácio Mini, Santa } \\
\text { Ana, Santa Maria Maior e } \\
\text { Loreto. }\end{array}$ & $\begin{array}{l}\text { Parque Nacional de Iguaçu. } \\
\text { Sítio Arqueológico de São Miguel das Missões. }\end{array}$ & $\begin{array}{l}\text { Sítio Arqueológico de } \\
\text { Santísseima Trinidad Del } \\
\text { Paraná e Sítio Arqueológico } \\
\text { de Jesus de Taravangue. }\end{array}$ \\
\hline Ecoturismo & $\begin{array}{l}\text { Parque Nacional de } \\
\text { Iguaçu, } \\
\text { Complexo Turístico La } \\
\text { Aripuca e Parque de Aves } \\
\text { Guira Oga (Puerto Iguaçu). } \\
\text { Minas de pedras preciosas } \\
\text { (Wanda) }\end{array}$ & $\begin{array}{l}\text { Parque Nacional de Iguaçu, Cataratas do Iguaçu. } \\
\text { Lago de Itaipu, Refúgio Biológico Bela Vista; } \\
\text { Parque das Aves, Macuco Safári, Trilha do Poço } \\
\text { Preto, Trilha da Bananeira, Linha Martins, Porta } \\
\text { Canoas, Passeio das Águas (Foa do Iguaçu) } \\
\text { Passeio ecológico no Lago Itaipu (Itapulândia). } \\
\text { Rio Paraná, Parque Nacional da Ilha Grande, Ilha } \\
\text { Grande e Caminhada Ecológica (Guairá) }\end{array}$ & $\begin{array}{l}\text { Salto de Monday, Estação do } \\
\text { Tape Avirú, Zoológico e } \\
\text { Centro de Investigação de } \\
\text { Animais Silvestres e Museu } \\
\text { ecológico (Presidente Franco) }\end{array}$ \\
\hline Aventura & $\begin{array}{l}\text { Sendero Macuco e Gran } \\
\text { Aventura (Parque Nacional } \\
\text { de Iguaçu- Puerto } \\
\text { Iguassu). }\end{array}$ & $\begin{array}{l}\text { Passeio de helicóptero, passeio de barco (Macuco } \\
\text { Safári), Cânion Iguaçu, pesca desportiva (Lago de } \\
\text { Itaipu), Trilha do Poço Preto, Trilha da Bananeira, } \\
\text { Linha Martins, Porto Canoas, Passeio das Águas } \\
\text { (Foz do Iguaçu). } \\
\text { Caminho das Missões,Passeio de Bicicleta, } \\
\text { Cavalgada do Rolador e Cavalgada Guaranítica } \\
\text { (RS) }\end{array}$ & $\begin{array}{l}\text { Salto do Monday, rapel e } \\
\text { escalada (Presidente Franco) }\end{array}$ \\
\hline
\end{tabular}




\begin{tabular}{|c|c|c|c|}
\hline Cultural & $\begin{array}{l}\text { Sítios Arqueológicos de } \\
\text { San Ignácio Mini, Santa } \\
\text { Ana, Santa Maria Maior e } \\
\text { Loreto. } \\
\text { Aldeia de Índios Mbya } \\
\text { Guarani (Puerto lguassu). } \\
\text { Museu Arqueológico e } \\
\text { Histórico Andrés Guacuvari } \\
\text { e Museu Aníbal Cambas. }\end{array}$ & $\begin{array}{l}\text { Ecomuseu (Foz do lguaçu). } \\
\text { Igreja Senhor do Perdão, Museu Municipal e } \\
\text { Alelier Frei Pacífico (Guairá). } \\
\text { Santuário do Caaró (Caibaté). } \\
\text { Cerro do Inhacurutum, Santuário Assunção do ljuí } \\
\text { (Roque Gonzáles). } \\
\text { Sítio Arqueológico de São Lourenço, Igreja Matriz } \\
\text { e Circuito das Imagens Missioneiras (São Luiz } \\
\text { Gonzaga). } \\
\text { Sítio Arqueológico de São Miguel Arcanjo, } \\
\text { Espetáculo de Som e Luz e Circuito das Imagens } \\
\text { Missioneiras (São Miguel das Missões). } \\
\text { Sitio Arqueológico de São Nicolau e Circuito das } \\
\text { Imagens Missioneiras ( São Nicolau). } \\
\text { Catedral de Santo Ângelo e Circuito das Imagens } \\
\text { Missioneiras (Santo Ângelo). } \\
\text { Circuito das Imagens Missioneiras (Santo Antonio } \\
\text { das Missões). }\end{array}$ & 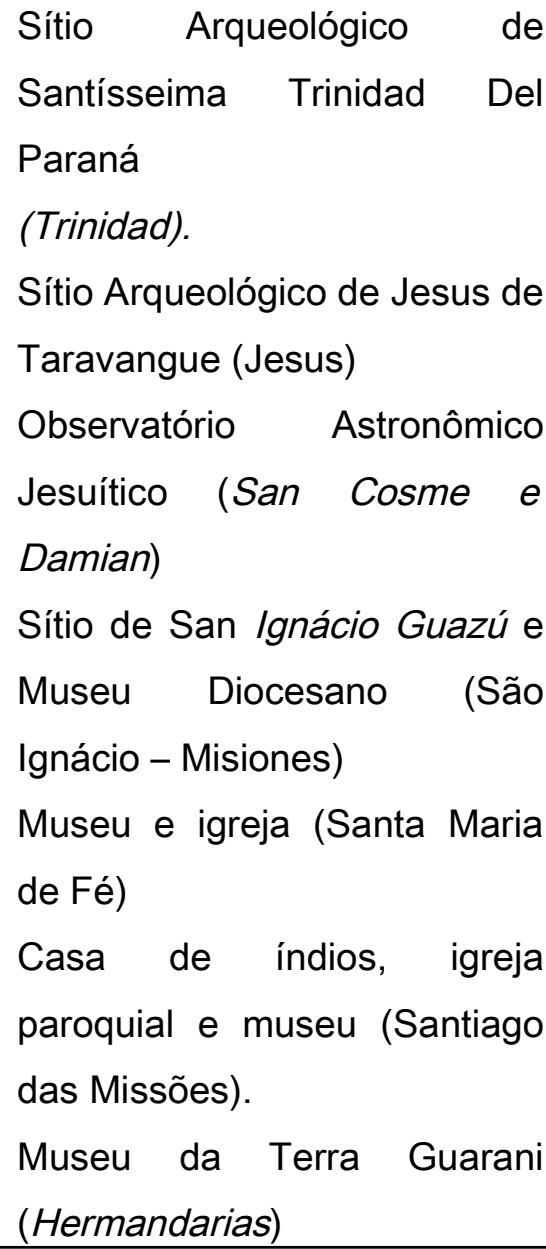 \\
\hline
\end{tabular}

Figura 48: quadro sobre os principais atrativos do roteiro iguaçu-missões

Fonte: montado a partir de: 


\subsubsection{PROGRAMA DE COOPERAÇÃO INSTITUTO ANDALUZ-INSTITUTO DO PATRIMÔNIO HISTÓRICO E ARTÍSTICO NACIONAL (IAPH-IPHAN)}

Consiste em um acordo de colaboração entre Instituto AndaLuz do Patrimônio Histórico (Espanha) e Instituto de Patrimônio Histórico e Artístico do Brasil, que prevê estabelecimento de relações de cooperação de caráter cientifico, tecnológico, formativo e cultural, em relação a documentação a conservação a formação e a difusão do patrimônio histórico da Região das Missões. O objetivo do IPHAN ao solicitar a colaboração do IAPH tem por objetivo preparar o s sítios arqueológicos para o uso turístico numa perspectiva sustentável.

Guia da paisagem - instrumento metodológico que pode unir ações mais complexas e diretas para atuar nos territórios das missões.

Este acordo envolve quatro projetos: projeto valorização do patrimônio e preparação para uso turístico no território das missões (1); projeto para la prospecção geo física na área arqueológica de São Miguel (2); projeto de estudo das coleções escultóricas das missões (3) e projeto de intervenção no museu Lucio Costa em São Miguel(4).

Em relações a $s$ ações propostas por este projeto foram realizadas as três primeiras fases do projeto $\left(1^{\circ}\right)$ que são: definição da metodologia e recopilação de documentação básica; inventário e caracterização do patrimônio cultural e do modelo 
turístico das missões; diagnóstico e perspectivas. Pra integralização deste projeto resta somente a fase de elaboração do documento e estratégia de elaboração. 


\begin{tabular}{|c|c|c|c|c|}
\hline & 1 & 2 & 3 & 4 \\
\hline Objetivos & $\begin{array}{l}\text { Analisar as condições atuais } \\
\text { do patrimônio cultural local e } \\
\text { prepará-lo para uso turístico. }\end{array}$ & $\begin{array}{lr}\text { Facilitar } & \text { a } \\
\text { identificação, } & \\
\text { proteção } & \text { e } \\
\text { conservação } & \text { material } \\
\text { paisagística } & \text { e } \\
\text { ambiental da } & \text { zona } \\
\text { arqueológica e seu } \\
\text { entorno. }\end{array}$ & $\begin{array}{lr}\text { Facilitar } & \text { o } \\
\text { conhecimento } & \text { a } \\
\text { interpretação e } & \text { a } \\
\text { valorização } & \text { das } \\
\text { esculturas } & \text { que } \\
\text { compõem o acervo } \\
\text { das missões. Além de } \\
\text { compreender } \\
\text { aspectos } \\
\text { museograficos } \\
\text { museológicos } \\
\text { existentes no museu } \\
\text { Lucio Costa. }\end{array}$ & $\begin{array}{l}\text { Garantir as } \\
\text { adequadas condições } \\
\text { de conservação da } \\
\text { coleção e do edifício } \\
\text { do museo Lucio } \\
\text { Costa. Revisar os } \\
\text { critérios } \\
\text { museográficoe } \\
\text { museológicos } \\
\text { existentes no museu e } \\
\text { valorizar o prédio } \\
\text { projetado por um dos } \\
\text { arquitetos do museu } \\
\text { contemporâneo mais }\end{array}$ \\
\hline
\end{tabular}




\begin{tabular}{|c|c|c|c|c|}
\hline & & & & $\begin{array}{l}\text { relevantes } \\
\text { panorama } \\
\text { internacional }\end{array}$ \\
\hline $\begin{array}{l}\text { Resultados } \\
\text { Esperados }\end{array}$ & $\begin{array}{l}\text { - definição do âmbito e da } \\
\text { metodologia de estudo } \\
\text { - coleta de dados de recursos } \\
\text { patrimoniais da zona de } \\
\text { estudo } \\
\text { - inventário e caracterização } \\
\text { do patrimônio cultural e do } \\
\text { modelo turístico das missões } \\
\text { - elaboração do diagnóstico e } \\
\text { perspectiva } \\
\text { - estudo da capacidade } \\
\text { receptiva } \\
\text { - definição de estratégias e } \\
\text { propostas de atuação. }\end{array}$ & $\begin{array}{l}\text { - delimitação da } \\
\text { extensão real do sítio } \\
\text { arqueológico de São } \\
\text { Miguel e definição do } \\
\text { seu entorno } \\
\text { - localização do plano } \\
\text { urbano (principais } \\
\text { áreas redes viárias } \\
\text { infra-estruturas). } \\
\text { - identificação de } \\
\text { estruturas urbanas e } \\
\text { peri urbanas sua } \\
\text { proteção e } \\
\text { recuperação. }\end{array}$ & $\begin{array}{l}\text { - melhoria no } \\
\text { conhecimento } \\
\text { iconográfico da } \\
\text { coleção escultórica no } \\
\text { museu das missões } \\
\text { - melhoria nas } \\
\text { condições de } \\
\text { conservação da } \\
\text { apresentação } \\
\text { coleção escultórica do } \\
\text { museu Lucio Costa } \\
\text { - transferência da } \\
\text { metodologia sobre o } \\
\text { estudo de bens } \\
\text { móveis elaboração de um } \\
\text { - eatálogo inventário } \\
\text { das esculturas dos }\end{array}$ & $\begin{array}{l}\text { - melhoria nas } \\
\text { condições de } \\
\text { conservação da } \\
\text { coleção do museu } \\
\text { Lucio Costa } \\
\text { - desenvolvimento de } \\
\text { um projeto } \\
\text { museologico que } \\
\text { responda as } \\
\text { tendências atuais de } \\
\text { apresentação } \\
\text { bens dos }\end{array}$ \\
\hline
\end{tabular}




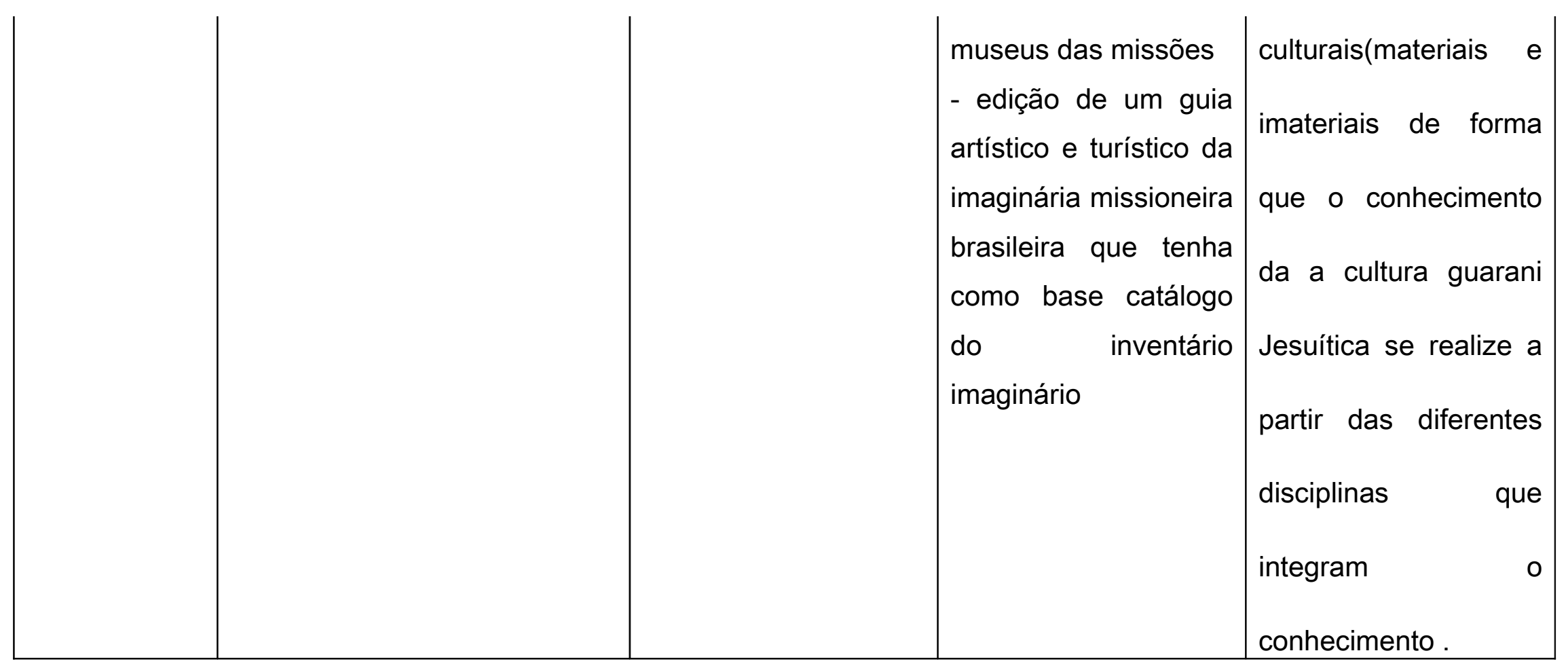

Figura 49: quadro dos objetivos e resultados esperados do projeto 


\section{CONSIDERAÇÕES FINAIS}

Mas, afinal, somos geógrafos porque estamos preocupados com uma seção da realidade que é de interesse contínuo e porque, nesse campo, podemos determinar a aproximação do ideal à realidade. (SAUER, 2000, p.98)

A configuração atual da Região Turística das Missões, que engloba territórios

transfronteiriços contíguos da Argentina, do Brasil, do Paraguai e do Uruguai, é resultante da forma com que o seu meio natural foi apropriado pelos grupos sociais que aí se sucederam no decorrer de sua evolução histórica, deixando suas marcas e referências no espaço por eles ocupado. Esta é caracterizada por três períodos, ou fases de ocupação, bem distintas: a primeira fase ou também conhecida como período pré-missioneiro ou pré-jesuítico que remonta desde 0s 12700 anos antes da chegada dos colonizadores europeus até a instalação das Reduções JesuíticoGuarani. Nesse período os Guarani mantinham relativa harmonia com o ambiente 
natural. A segunda fase, conhecida como fase jesuítica ou missioneira que vai desde a implantação até a destruição das reduções e seus povos, na qual o modo com que os Guarani se relacionam com a natureza foi se modificando em decorrência da imposição dominação e da visão utilitária européia. Nesse período houve a introdução de espécies exóticas tanto na fauna como na flora. Na terceira fase, a fase pós-jesuítica ou pós missioneira, caracterizada por uma relação mais agressiva entre os novos habitantes (imigrantes) com o meio ambiente. Houve uma exploração irracional dos recursos naturais pautada em um modelo econômico inadequado para as características ambientais locais. Hoje pode-se dizer que a matriz produtiva local, baseada na agropecuária, oferece forte pressão aos recursos naturais existentes.

Nesse contexto, a comunidade regional busca no turismo uma alternativa para a melhoria da qualidade de vida de sua população. Crê que a atividade turística pode ser um instrumento eficaz de crescimento sócio-econômico podendo também contribuir para a proteção dos sítios arqueológicos que integram o conjunto patrimonial regional. 
Constatou-se que nas últimas décadas surgiram muitas iniciativas em prol do desenvolvimento do turismo regional. Algumas delas acabaram se transformando em programas e projetos como os que foram trabalhados no capítulo três, página 123.

Assim, todas as iniciativas implantadas na região têm por objetivo resgatar as obras realizadas pela comunidade jesuítica, divulgar a História das Missões, consolidar a região como um Pólo Turístico Internacional e, principalmente, contribuir para o desenvolvimento e a integração regional.

Observa-se no entanto, que a s iniciativas não têm atingido plenamente os objetivos pretendidos porque as distâncias são grandes entre os centros maiores tanto no Brasil como na Argentina, no Paraguai e no Uruguai. A infra-estrutura ainda é precária e as estradas estão comprometidas pela falta de manutenção, hotéis e restaurantes não oferecem muitas condições para atender um número grande de visitantes. Existem poucas opções de lazer e outros modalidades de turismo além do turismo histórico cultural. Há também uma idealização dos recursos potencialmente 
capazes de contribuir para o incremento do turismo, principalmente no que se refere à qualidade dos serviços oferecidos e ao nível de conscientização da comunidade regional como agente do desenvolvimento e não fator de exploração.

Essas iniciativas funcionam muito bem no papel, pois a Região tem Patrimônio, existem muitos projetos e grandes possibilidades de recursos para investimentos através de instituições financeiras nacionais e internacionais. Mas na prática, poucas são as mudanças. Acredita-se que um dos fatores que contribuem para isso seja a inexperiência de trabalhar em equipes multidisciplinares, as pessoas envolvidas nos projetos nem sempre são aquelas que possuem a maior experiência ou não estão legadas ao tema. Muitas vezes os profissionais contratados, apesar de qualificados, estão acostumados com a dinâmica de grandes centros turísticos não adaptando suas propostas para a realidade local e regional. Resulta que os pequenos empreendedores do turismo e a comunidade locam têm suas expectativas frustradas, pois há um enorme envolvimento e não há o retorno esperado. Há também as políticas e vaidades locais que interferem nos resultados. 
Para que haja uma mudança nessa realidade recomenda-se:

- Que a História Regional seja valorizada, não só em âmbito acadêmico mas na comunidade regional como um todo.

- Que na área de educação, se realizem cursos de capacitação para que os professores possam trabalhar com "educação para o turismo" no ensino básico e médio.

- Que nas instituições de nível superior, sejam elaborados projetos multidisciplinares que contribuam para a dinamização da atividade turística na região.

- Que haja permanentes investimentos na área de qualificação na prestação de serviços.

- Que os empreendedores prestadores de serviços tenham sejam conscientizados sobre a necessidade da melhoria da qualificação e na profissionalização de seus fundiconários. 
- Que os projetos propostos sejam acompanhados por profissionais que

tenham conhecimento da realidade local.

\section{REFERÊNCIAS BIBLIOGRÁFICAS}

ABOU, Selim. La "Republica" Jesuítica de los Guaraníes (1609-1768) y su Herancia. Buenos Aires: Manrique Zago/Selin Abou/UNESCO, 1996.

ANDRADE, Manuel Correia de. O Planejamento Regional e o Problema Agrário no Brasil. São Paulo: HUCITEC, 1976.

AZEVEDO, Ferdinando. Uma vista rápida da Companhia de Jesus no mundo e no Brasil. In: Santo Inácio e os Jesuítas. Ed. Especial. Porto Alegre: Notícias, julho de 1984.

BAIOTO, Rafael; QUEVEDO, Júlio. São Miguel das Missões. Porto Alegre: Martins Livreiro, 1997.

BAIOTO, Rafael; QUEVEDO, Júlio; NASCIMENTO, Anna Olivia do. São Luiz Gonzaga e São Lourenço Mártir. Porto Alegre : Martins Livreiro, 1998. 
BARBACRI, Norma e GREMENTIERI, Fabio. Avaliação Do Conjunto Patrimonial. In:CUSTÓDIO, Antônio Bolcato (org). Missão Jesuítica dos Guarani. Programa de Capacitação para Conservação, Gestão e Desenvolvimento Sustentável das Missões Jesuíticas dos Guarani (2003-2005). Brasília: IPHAN, Unesco, WMF, 2004. Relatório.

BOFF, Claudete. A Imaginária Guarani: o Acervo do Museu das Missões. Santo Ângelo: CCM/URI - EDIURI, 2005.

BRITTO, Luiz Navarro de. Política e Espaço Regional. São Paulo: Nobel, 1986 (Coleção Espaços).

BRUXEL, Arnaldo. Os Trinta Povos Guaranis. 2. ed. Porto Alegre: Est/ Nova Dimensão, 1987.

CARVALHO, Pompeu Figueiredo de Patrimônio Histórico e Artístico nas Cidades Médias Paulistas: A construção do lugar. In: Yazigi, Eduardo; CARLOS, Ana F.A e CRUZ, Rita de Cássia A. da. Turismo: Espaço, Paisagem e Cultura. São Paulo: Hucitec, 1996.(100-111)

COLVERO, Ronaldo. Negócios na Madrugada. O comércio ilícito na fronteira do Rio Grande do Sul. Passo Fundo: UPF, 2004.

CORRÊA, Roberto Lobato. Região e Organização Espacial. São Paulo: Ática, 1987.

CORREAA, Roberto Lobato. Monumentos, Política e Espaço. In: Rosendahl, Zeny e CORREAA, Roberto Lobato (orgs). Geografia: Temas sobre Cultura e Espaço. Rio de Janeiro: EDUERJ, 2005. 
COSTA, Elmar Gomes da, FONSECA, Ricardo e Schimitt, Ricardo. História llustrada do Rio Grande do Sul. Porto Alegre: RBS Publicações, 2004.

CUSTÓDIO, Antonio Bolcato. Seminário de Fronteiras do Brasil. IPHAN, Ministério da Cultura, UFGRS, 1 A 12 DE junho de 2006.

DALTO, Renato. O Mundo Missioneiro. In: TAVARES, Eduardo (org.). Missões Jesuítico-Guarani. São Leopoldo: UNISINOS, 1999. (12-47)

DAMIANI, Nadir Lurdes. Cultura Material, Patrimônio e Educação: As Reduções Jesuítico-Guarani e o Ensino de História. São Leopoldo: Programa de PósGraduação em História da UNISINOS, 2004. Dissertação não Publicada.

DIAS, Reinaldo e AGUIAR, Marina Rodrigues de. Fundamentos do Turismo: Conceitos, normas e definições. Campinas, SP: Alinea, 2002.

FLORES, Moacyr. Colonialismo e Missões Jesuíticas. Porto Alegre: Instituto de Cultura, 1983.

FLORES, Moacyr. História do Rio Grande do Sul. 7.ed. Porto Alegre: Ediplat, 2003.

FREITAS, Décio. Utopia Missioneira. In: TAVARES, Eduardo (org.). Missões Jesuítico-Guarani. São Leopoldo: UNISINOS, 1999. (48-66)

FURLON, Guillermo. Misiones y Sus Pueblos de Guaranies. Buenos Aires: Theoria, 1962. 
GASTAL, Suzana. O produto Cidade; Caminhos de Cultura, Caminhos de Turismo. In: CASTROGIOVANNI, Antônio Carlos e GASTAL, Suzana (org) Turismo Urbano: Cidades, Sites de Exilação Turística. Porto Alegre: edição dos autores, 1999 (34-43).

GAZEANO, Jorge O. Geopolítica de las Misiones. In: GOLDSTEIN, Leon (coord.) Las Misiones Jesuíticas Guaraníes. Buenos Aires: Manrique Zago, 1997. (Col. Patrimonio de la Humanidad). (75-90)

GOLIN, Luiz Carlos. A Fronteira - Governos e movimentos espontâneos na fixação dos limites do Brasil com o Uruguai e a Argentina. Porto Alegre: L\&PM, 2002. (Volume 1).

GUTIERREZ, Ramón. A Missão Jesuítica dos Guaranis. Rio de Janeiro: Fundação Pró Memória/UNESCO, 1987.

Instituto Brasileiro do Patrimônio Cultural (12 ${ }^{\circ}$ Coordenação Regional) Projeto Integrado de Valorização dos Sítios Arqueológicos Missioneiros do Brasil. In: II Congresso Internacional de Reabilitacion Del Patrimônio Arquitectonico y Edificacion. II La Salvaguarda Del Patrimônio Jesuítico. 5 al 7 de septriembre de 1994. Posadas; Montoya, 1995. Seminário Post Congreso. Misiones, Argentina.

INSTITUTO SOCIO AMBIENTAL. Povos Indígenas no Brasil. Disponível em http://www.socioambiental.org/inst/sitemap.shtm. Acesso em 24/02/06

KERN, Arno Alvarez. Antecedentes Indígenas. Porto Alegre: UFRGS, 1994. Síntese Rio-Grandense 16/17. 
Arno Alvarez. Missões: Uma Utopia Política. Porto Alegre: Mercado Aberto, 1982.

Arno Alvarez. O Rio da Prata Colonial e as Missões Jesuíticas. Primeira Reunião Científica do Instituto Internacional de Estudos Coloniais do Cone Sul (IIECC). Montevideo. 24 e 25 de outubro de 2002. Texto não publicado.

KOTHER, Beatriz. Patrimônio Histórico e Turismo. In: GONÇALVES, Ana Beatriz e BOFF, Claudete. Turismo e Cultura. A história e os Atrativos Regionais. Santo Ângelo, RS: Gráfica Venâncio Ayres, 2001 (105-110)

LEMOS, Amália Inês Geraiges. Turismo, Modernidade e Globalização: São Paulo, Metrópole Mundial. In. RODRIGUES, Adyr Aparecida Balastreri (org) Turismo. Desenvolvimento Local. São Paulo: Hucitec, 1997.(42-64)

LESSA, Barbosa. O Alicerce Guarani. In: TAVARES, Eduardo (org.). Missões Jesuítico-Guarani. São Leopoldo: UNISINOS, 1999. (69-85)

MACHADO, Rosane Vescia. Tombamento a Nível Federal: Proteção ao Patrimônio Cultural. São Leopoldo-RS: Unisinos, Centro de Educação e Humanismo, 1992. Dissertação não Publicada.

MARQUES, Alvarino da Fontoura. Episódios do Ciclo do Charque. Porto Alegre: Edigal, 1987.

MARTIN, André Roberto. Fronteiras e Nações. 4.ed. São Paulo: Contexto, 1998.

MARTINS, Nestor Torelly. O Legado Arquitetônico. In: TAVARES, Eduardo (org.). Missões Jesuítico-Guarani. São Leopoldo: UNISINOS, 1999.(112 a 139) 
MELIÀ, Bartomeu. El Guaraní Conquistado y Reducido. V. 5. Asunción, Paraguay, CEADUC,1986.

Menezes, Ulpiano T. Bezerra de. Os "usos culturais" da cultura. Contribuição para uma abordagem crítica das práticas e políticas culturais

MEUCCI, Nádia Raupp. Tranqueira Invicta. Disponivel em http://www.fotonadia.art.br/tranqueira/tq.html. Acesso em 24/02/06

MIORIN, Vera Maria Fávila. Determinação do Sítio Urbano nas Reduções. 1 Simpósio Nacional de Estudos Missioneiros. A Experiencia Reducional: Os Guarani. Santa Rosa, RS: Faculdade de Filosofia, Ciencias e Letras Dom Bosco, 1975. (157166)

MONTOYA, Pe. Antônio Ruiz de. Conquista espiritual feita pelos religiosos da Companhia de Jesus nas províncias do Paraguai, Paraná, Uruguai e Tape. Trad. Vermácula: Arnaldo Bruxel. Revisão do texto, apres. e notas: Arthur Rabuske. Porto Alegre: Martins Livreiro, 1985.

MORAES, Antonio Carlos Robert. Capitalismo Geografia e Meio Ambiente. São Paulo: DG/USP, 2000. Tese para concurso de obtenção de título de Livre Docente. Não Publicado.

MORALES, Martín Maia. La Órdem de Jesús. In: GOLDSTEIN, Leon (coord.) Las Misiones Jesuíticas Guaraníes. Buenos Aires: Manrique Zago, 1997.(47-75) 
MOREL, Joaquim Bosque. O Patrimônio da Humanidade. In: Yazigi, Eduardo; CARLOS, Ana F.A e CRUZ, Rita de Cássia A. da. Turismo: Espaço, Paisagem e Cultura. São Paulo; Hucitec, 1996.(77-87)

MUJICA, Elias. Análise da Situação Recomendações. In: CUSTÓDIO Antônio Bolcato (org). Missão Jesuítica dos Guaranis. Programa de Capacitação para Conservação, Gestão e Desenvolvimento Sustentável das Missões Jesuíticas dos Guarani 2003-(2004). Brasília: IPHAN, Unesco, Wmf, 2004-205. Relatório

NECKER, Louis. Índios Guaranies y Chamanes Franciscanos. Las Primeras Reducciones Del Paraguay (1580-1800). Asunción: Universidad Católica, 1990.

NAGEL, Liane Maria - Missões Guarani - Jesuítica, História do Passado Colonial Platino, Roteiro Turístico-Cultural de Integração no Presente. In: GONÇALVES, Ana Beatriz e Boff, Claudete (orgs.) Turismo Cultural: a História e os Atrativos Regionais. Santo Ângelo: Gráfica Venâncio Aires, 2001.

NEGRETE, Ângela Sanchez. A cultura nas Missões Jesuítico - Guarani. In: MAGTER, Mary Mabell Pellizzer (coord). Circuito Internacional -Misiones Jesuítico Guaranies. Posadas/Misiones: Unam, 2005.

NOGUEIRA, Carmen Regina Dorneles. O Patrimônio Cultural como Potenciacilidade para o Desenvolvimento do Turismo: o caso da Região Turística Missioneira. In: GONÇALVES, Ana Beatriz e Boff, Claudete (orgs.) Turismo Cultural: a História e os Atrativos Regionais. Santo Ângelo: Gráfica Venâncio Aires, 2001.

, Carmen Regina Dorneles. Turismo no Mercosul: O Circuito Internacional das Missões Jesuítico-Guarani. São Paulo: DG/USP, 1999. Dissertação não publicada. 
NUNES, Zeno Cardoso e NUNES, Rui Cardoso. Dicionário de Regionalismo do Rio Grande do Sul. Porto Alegre: Martins Livreiro, 1984.

\section{OMT - Conceito Turismo}

PACHECO, Rodrigo Fernando Casa Grande. Patrimônio: Uma Questão da História. São Leopoldo, RS: Unisinos, 1994. Dissertação não Publicada.

PELLEGRINI, Filho Américo. Ecologia, cultura e Turismo. Campinas: Papirus, 1991.

PELLIZZER, Mary Mabel (coord). Circuito Internacional Misiones Jesuítico Guaraníes. Posadas, Misiones: Universidade Nacional de Misiones, 2005.

PESAVENTO, Sandra Jotahy. Missões, um espaço no tempo: paisagem da memória. Seminário de Fronteiras do Brasil. IPHAN, Ministério da Cultura, UFGRS, 1 A 12 DE junho de 2006.

Sandra. História do Rio Grande do Sul. 2. ed. Porto Alegre: Mercado Aberto, 1982.

PINTO, Luís Flodoardo Silva. As Missões Orientais. Epopéia Jesuítica no Sul do Brasil. Porto Alegre: Estado do Rio Grande do Sul AGE, 2002. (Série Léxico Literário do Cone Sul)

POENITIZ, Alfredo. Um proyecto de arqueologia histórico. El âmbito rural de lãs Missinones em la Cuenca Del Rio Aguapey. In: Curso Oficina sobre a Conservação, Gestão e Desenvolvimento Sustentável das Missões Jesuíticas dos Guarani. São Miguel das Missões: IPHAN, UNESCO, ICOM, WMF, 2003. (3 a 14 de novembro) Comunicações. 
PORTUGUEZ, Anderson Pereira (org.) Turismo, Memória e Patrimônio Cultural. São Paulo: Roço, 2004.

QUEVEDO, Júlio e TAMAQUEVIS, José C. Rio Grande do Sul: Aspectos da História. 6. ed. Porto Alegre: Martins Livreiro, 1999.

QUEVEDO, Júlio. A Guerra Guaranítica. São Paulo : Ática, 1996.

QUEVEDO, Júlio. Guerreiros e Jesuítas na Utopia do Prata. Bauru, SP: EDUSC, 2000.

RODRIGUES, Adyr Apparecida Balastreri. Desenvolvimento sustentável e atividade Turística. In. RODRIGUES, Adyr Aparecida Balastreri (org) Turismo. Desenvolvimento Local. São Paulo: Hucitec, 1997.(42-64)

RODRIGUES, André Figueiredo. Como Elaborar Referências Bibliográficas. 5. ed. São Paulo: Associação Editorial Humanistas, 2004. (Coleção Metodológicas, v.1)

RODRIGUES, André Figueiredo. Como Elaborar Citações e Notas de Rodapés. 3. ed. São Paulo: Associação Editorial Humanistas, 2005. (Coleção Metodológicas, v.2)

RODRIGUES, André Figueiredo. Como Elaborar e Apresentar Monografias.São Paulo: Associação Editorial Humanistas, 2005. (Coleção Metodológicas, v.3) RODRIGUES, Marly. De quem é o patrimônio? Um olhar sobre a prática preservacionalista em São Paulo. In: Revista do IPHAN, n² 24/1996.(195-203)

ROLIM, Cássio. Como Analisar as Regiões Transfronteiriças: esboços de um enquadramento teórico-metodológico a partir do caso de Fozl do Iguaçu. São Paulo: NEREUS/USP, TD NEREUS 05-2004. 
SAUER, Carl. Desenvolvimentos Recentes em Geografia Cultural. In: Corrêa, Roberto Lobato e ROSENDAHL, Zeni. (orgs).Geografia Cultural: Um Século(1). Rio de Janeiro: EdUERJ, 2000.(15-98)

, Carl. Geografia Cultural. In: Corrêa, Roberto Lobato e ROSENDAHL, Zeni. (orgs).Geografia Cultural: Um Século(1). Rio de Janeiro: EdUERJ, 2000.(110)

WAGNER, Philip e MIKESELL, Marvin. Temas da Geografia Cultural. In: Corrêa, Roberto Lobato e ROSENDAHL, Zeni. (orgs).Geografia Cultural: Um Século(1). Rio de Janeiro: EdUERJ, 2000.(15-98)

SCHADEM, Egon. Aspectos Fundamentais da Cultura Guarani. São Paulo: EPU/EDUSP, 1974.

SCHIMITZ, Pedro Ignácio. A Companhia de Jesus e a Missão. In: TAVARES, Eduardo (org.). Missões Jesuítico-Guarani. São Leopoldo: UNISINOS, 1999. (140156)

SEBE, José Carlos. Os Jesuítas. São Paulo: Brasiliense, 1982. (Tudo é História).

SILVA, Luiz Cláudio da. Paisagem e Meio Ambiente. In: Curso Oficina sobre a Conservação, Gestão e Desenvolvimento Sustentável das Missões Jesuíticas dos Guarani. São Miguel das Missões: IPHAN, UNESCO, ICOM, WMF, 2003. (3 a 14 de novembro) Comunicações. 
SILVEIRA, Maria Laura. A Região e a Invenção da Viabilidade do Território. In: SOUZA, Maria Adélia Aparecida de (org.) Território brasileiro: usos e abusos. Campinas: Edições Territorial, 2003.

SIMON, Mário. As Missões dos Sete Povos. Santo Ângelo: Talento, 2004. II (Coleção de Bolso)

SIMON, Mário. Os Sete Povos das Missões. Porto Alegre: Martins Livreiro, 1987.

SOUZA, José Otávio Catafesto. O Legado Missioneiro Frente as Sociedades do Continente Sul Americano no Terceiro Milênio. In: X Simpósio Nacional de Estudos Missioneiros. A Experiência Missioneira: Um Marco Histórico Para Integração Latino Americana. Santa Rosa, RS: Unijuí, Departamento de Ciências Sociais, Centro de Estudos Missioneiros, 1994. (448-457)

SOUZA, José Otávio Catafesto. Uma Introdução ao Sistema Técnico-Econômico Guarani. Porto Alegre: Programa de Pós-Graduação e Antropologia Social da UFRGS, 1997. Dissertação não publicada.

SOUZA, Marcelo José Lopes de. Como pode o Turismo Contribuir para o Desenvolvimento Local. In: RODRIGUES, Adyr Apparecida Balastreri. Balastreri (org) Turismo. Desenvolvimento Local. São Paulo: Hucitec, 1997. (17-22)

TOCCHETTO, Fernanda Bordin. A cultura Material do Guarani Missioneiro com Símbolo de Identidade étnica. Dissertação de Mestrado, UFSC, Florianópolis, 1991.

TRICÁRIO, Luciano Torres. O continente iberizado: uma cicatriz. São Paulo: FAU/USP, 1998. Trabalho de Graduação Interdisciplinar. Não Publicado. 
TRIGO, LUIZ Gonzaga Godoi. Turismo e Qualidade. Tendências Contemporâneas. Campinas, SP: Contexto, 1993.

VINUESA, Miguel Angel Trotiño. Turismo e Desenvolvimento nas Cidades Históricas Ibero-Americanas: Desafios e Oportunidades. In: PORTUGUES, Anderson Pereira (org.). Turismo Memória e Patrimônio Cultural. São Paulo: Rocca, 2004Tradução de Silvia Mariângela Spada. . (33-50).

WAIMBERG, Jaques A. Cidades como sites de exilação Turística. In: CASTROGIOVANNI, Antônio Carlos e GASTAL, Suzana (orgs.) Turismo Urbano: Cidades, Sites de Exitação Turística. Porto Alegre: edição dos autores, 1999. (9-21)

YÁZIGI, Eduardo. Civilização Urbana, planejamento e Turismo: discípulos do amanhecer. São Paulo; Contexto, 2003.

ZARTH, Paulo A. A Região Missioneira após as Missões. In: Simpósio Nacional de Estudos Missioneiros. 10, 1994. Santa Rosa. ANAIS. Santa Rosa: UNIJUI, 1994.(458-471). 